\title{
Economic optimal design of vertical breakwaters
}

Delft, August 1997

Master thesis of: H.G. Voortman

Examiner committee:

Prof. J.K. Vrijling (chairman)

Prof. K. d'Angremond

Prof. A.C.W.M. Vrouwenvelder

W.H Tutuarima MSc.

P.H.A.J.M. van Gelder MSc.

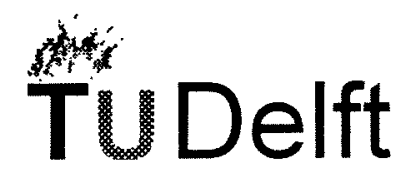



Design is decision making, in the face of uncertainty, with high penalties for error (Isaac Asimov, 1962) 



\section{Summary}

In Europe the interest in and the importance of vertical breakwaters is growing. A central point is the optimal geometry, e.g. the width and height of the breakwater caisson chosen such that the total costs over the lifetime of the structure are minimized.

Probabilistic design tools provide several methods to determine the probability of failure of a structure. In a design process however, the designer of the structure is faced with the problem of defining the acceptable probability of failure.

In general there are three ways to determine the optimal probability of failure:

- Consider the probability of dying of an individual due to collapse of the structure (individual point of view);

- Consider the probability of occurrence of a certain number of casualties in case of failure of the structure (societal point of view);

- Minimize the sum of initial investment and capitalized risk over the lifetime of the structure (economical optimization).

In the case of a breakwater without amenities the probability of loss of life due to failure is very small, but the economic losses can be severe. Therefore the application of the economical optimization is suitable.

In this study a framework for the optimization of vertical breakwaters is developed. The optimization procedure has been implemented in a numerical model. In this model three failure modes are considered:

- $\quad$ Sliding of the caisson over the rubble foundation (ultimate limit state);

- Overturning of the caisson (ultimate limit state);

- Wave transmission (serviceability limit state).

Several calculations have been made with the computer program. The results of the calculations show the following:

- The capitalized risk has a large influence on the optimal geometry of the structure;

- In general only one mechanism largely determines the probability of failure of an optimal designed vertical breakwater. This mechanism is in general the one which is most expensive to strengthen the breakwater for. In the situation chosen in this study, this is rotation failure of the caisson. The caisson width is the most expensive design variable;

- The optimal design is influenced by all random variables used in the design;

- Wave transmission influences the optimal geometry of a breakwater towards higher and narrower caissons. In the situation chosen in this study, a caisson height such that no wave transmission occurs seems optimal.

The developed model provides a good starting point for the development of more advanced optimization models. 



\section{Samenvatting}

In Europa is op dit moment sprake van een toenemende belangstelling voor verticale golfbrekers. Een belangrijk punt bij het ontwerp hiervan is de optimale geometrie. De optimale geometrie is gedefinieerd door die breedte en hoogte waarbij de totale kosten over de levensduur van de constructie minimaal zijn.

Probabilistische methoden bieden verscheidene manieren om de faalkans van een constructie te bepalen. In een ontwerpproces dient de ontwerper echter een uitspraak te doen over de acceptabele faalkans.

Drie gezichtspunten voor de bepaling van de acceptabele faalkans kunnen worden onderscheiden:

- Het gezichtspunt van het individu. Wat is de kans op overlijden van een individu als de constructie faalt;

- Het gezichtspunt van de maatschappij. Wat is de kans op een bepaald aantal doden in geval van falen van de constructie;

- Economische optimalisatie. Minimaliseer de som van investeringskosten en verwachte schadekosten over de levensduur van de constructie.

In het geval van een golfbreker waarbij geen sprake is van permanente aanwezigheid van grote aantallen mensen is de kans op doden in geval van falen zeer klein. De economische gevolgen kunnen echter aanzienlijk zijn. Daarom is de economische optimalisatie in dit geval geschikt.

In deze studie is een raamwerk ontwikkeld voor de optimalisatie van verticale golfbrekers. De optimalisatieprocedure is geïmplementeerd in een numeriek model. In dit model worden drie faalmechanismen beschouwd:

- Schuiven van het caisson over de stortsteenfundering (uiterste grenstoestand);

- Kantelen van het caisson (uiterste grenstoestand);

- Golftransmissie (bruikbaarheidsgrenstoestand).

Verschillende berekeningen zijn gemaakt met dit model. De resultaten tonen het volgende aan:

- Het gekapitaliseerde risico heeft een grote invloed op de optimale geometrie van de golfbreker.

- In het algemeen bepaalt slechts één mechanisme grotendeels de faalkans van een optimaal ontworpen verticale golfbreker. In het algemeen is dit het mechanisme dat het duurst is om de golfbreker ertegen te versterken. In deze studie is dat het kantelen van het caisson. De caissonbreedte is de duurste ontwerpvariabele;

- Het optimale ontwerp wordt beïnvloed door alle stochastische variabelen in het ontwerp;

- Golftransmissie beïnvloedt het optimale caissonontwerp in de richting van hogere en smallere caissons. In de situatie gekozen in deze studie lijkt het economisch om geen golftransmissie toe te laten.

Het ontwikkelde model biedt een goed startpunt voor de ontwikkeling van meer geavanceerde modellen. 



\section{Preface}

This is the final report of a study of economic optimal design of vertical breakwaters. The study was carried out as the final thesis of the study Civil Engineering at Delft University of Technology.

Readers especially interested in the background of optimization of vertical breakwaters including the capitalized risk, should refer to chapter 5. The results of several calculations are also discussed in this chapter. All calculation results are given in annex IV and VI through IX. Readers interested in the developed numerical model should refer to annexes III and V.

I want to thank the members of the examiner committee for their time and criticism. I believe it has certainly improved the end result.

Special thanks go to Prof. Han Vrijling for providing the opportunity to carry out the research for this thesis as an employee of the Hydraulic Engineering Section of Delft University of Technology. Furthermore I want to thank two of my colleagues. Harrie Kuijper MSc. for his guidance during the last few months and Pieter van Gelder MSc. for his help and for making sure I did not forget to take a short coffee break once in a while.

Hessel Voortman

Delft, 4 August 1997 


\section{Contents}

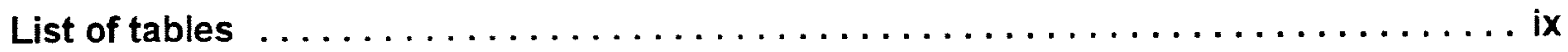

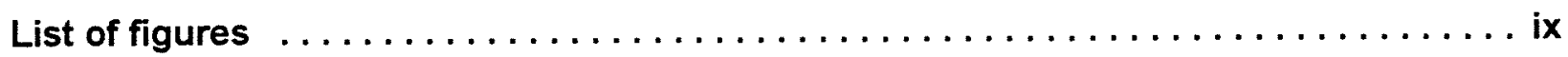

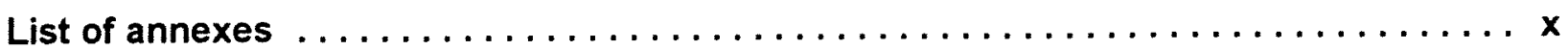

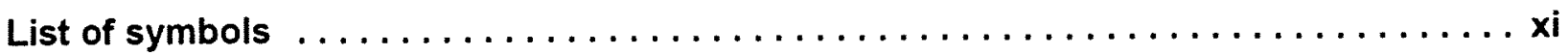

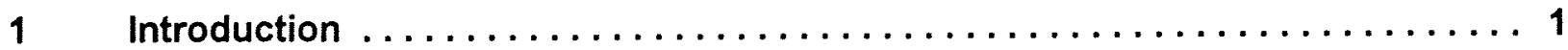

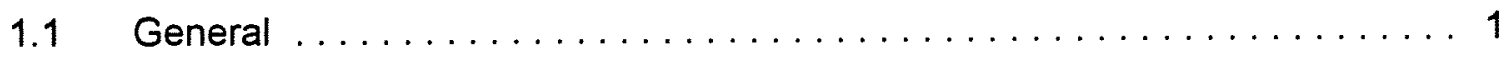

1.2 Optimal geometry of a breakwater structure $\ldots \ldots \ldots \ldots \ldots \ldots \ldots \ldots$

1.3 Objective of the study and working method $\ldots \ldots \ldots \ldots \ldots \ldots \ldots$

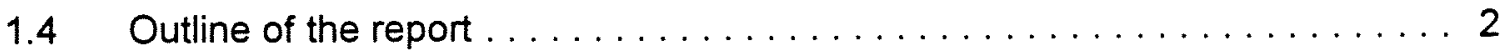

2 Functional requirements and failure modes of a vertical breakwater ....... 3

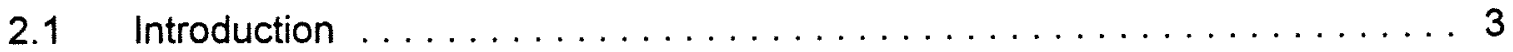

2.2 Main function of the breakwater $\ldots \ldots \ldots \ldots \ldots \ldots \ldots \ldots \ldots \ldots$

2.3 Failure mechanisms of the breakwater $\ldots \ldots \ldots \ldots \ldots \ldots \ldots \ldots$

3 Costs of construction and failure $\ldots \ldots \ldots \ldots \ldots \ldots \ldots \ldots \ldots \ldots$

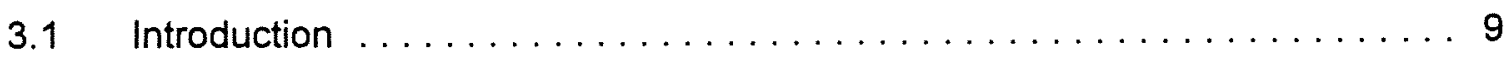

3.2 Total lifetime costs as a function of the design variables $\ldots \ldots \ldots \ldots \ldots 9$

3.3 Costs of the breakwater construction . . . . . . . . . . . . . . 11

3.3.1 Costs related to the breakwater cross section . . . . . . . . . . 11

3.3.2 Costs related to the total project (project costs) . . . . . . . . . 13

3.4 Costs related to failure of the breakwater $\ldots \ldots \ldots \ldots \ldots \ldots \ldots \ldots$

3.4 .1 General . . . . . . . . . . . . . . . . . . . . . . . 13

3.4.2 Damage due to interrupted harbour operations .......... 13

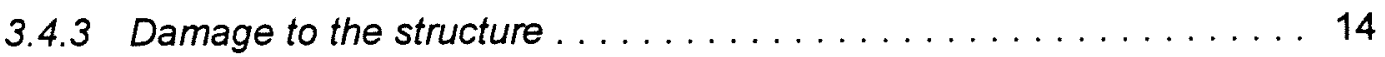

3.4.4 Fictitious example of damage costs . . . . . . . . . . . 14 
$4 \quad$ Minimization of the construction costs of a breakwater $\ldots \ldots \ldots \ldots \ldots \ldots$

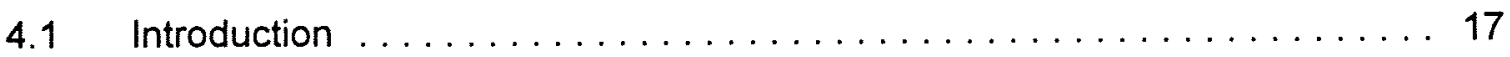

4.2 Properties of the used breakwater, the base case $\ldots \ldots \ldots \ldots \ldots \ldots 18$

4.3 Determination of the maximum design wave height $\ldots \ldots \ldots \ldots \ldots \ldots$

4.4 Transfer functions for the wave load . . . . . . . . . . . . . . 20

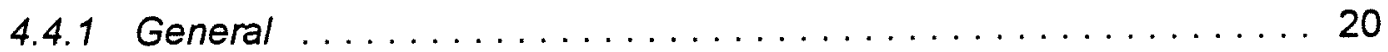

4.4 .2 Hydrostatic approach $\ldots \ldots \ldots \ldots \ldots \ldots \ldots \ldots \ldots \ldots \ldots \ldots \ldots . \ldots \ldots$

4.4 .3 Linear wave theory ........................ 23

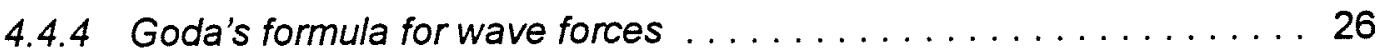

4.4.5 Comparison of the three wave load models . . . . . . . . . . . 29

4.5 Width of the caisson as a function of caisson height and wave height . . . . 30

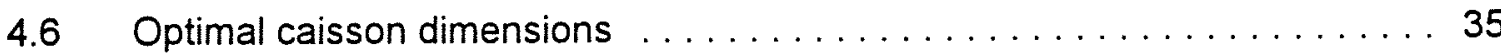

4.6.1 Hydrostatic approach of the wave forces . . . . . . . . . . . 35

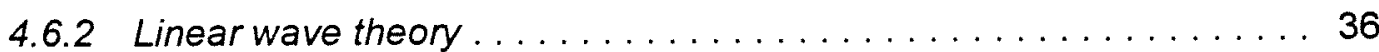

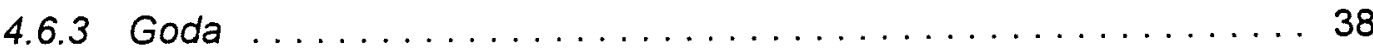

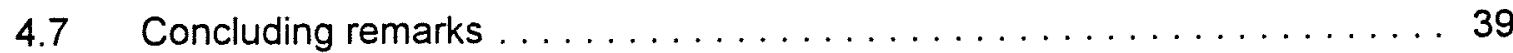

5 Minimization of the complete cost function $\ldots \ldots \ldots \ldots \ldots \ldots \ldots \ldots \ldots \ldots$

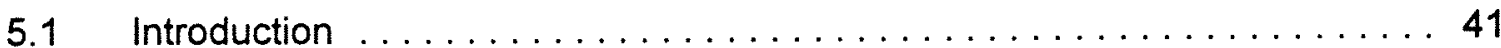

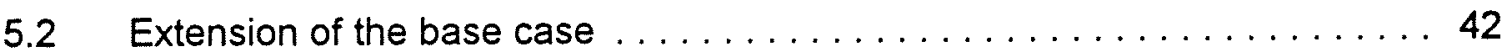

5.2.1 Geometry of the breakwater and costs . . . . . . . . . . 42

5.2 .2 Random variables ...........................44 43

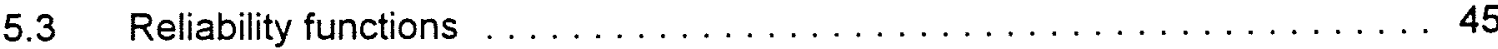

5.3 .1 Introduction ......................... 45

5.3.2 Reliability functions for ultimate limit states . . . . . . . . . 46

5.3.3 Reliability function for serviceability limit state (wave transmission) . . 48

5.4 Optimization with one random variable for ultimate limit states . . . . . . . 50

5.4 .1 Introduction ........................ 50

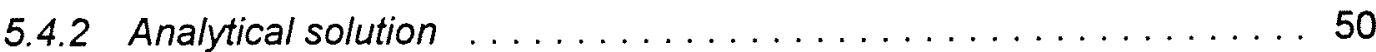

5.4.3 Influence of interest rate and lifetime of the structure . . . . . . . 52

5.5 Optimization with two random variables for ultimate limit states . . . . . . . 56

5.5 .1 Introduction ............................ 56

5.5 .2 Model input and results $\ldots \ldots \ldots \ldots \ldots \ldots \ldots \ldots \ldots \ldots \ldots$

5.6 Influence of wave transmission on the optimal design $\ldots \ldots \ldots \ldots \ldots \ldots 8$

5.6 .1 Introduction ........................... 58

5.6 .2 Model input and results $\ldots \ldots \ldots \ldots \ldots \ldots \ldots \ldots \ldots \ldots$

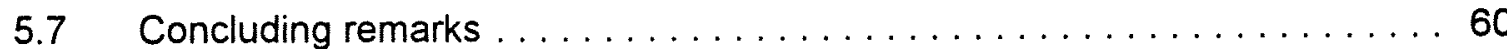

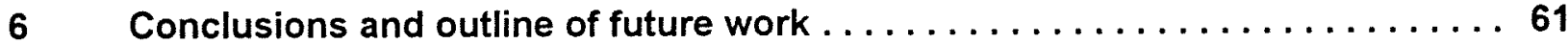

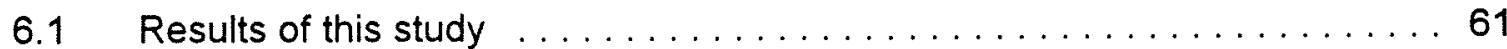

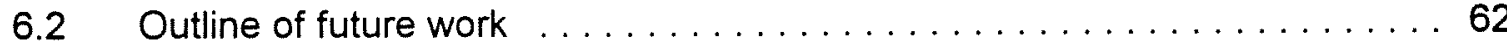

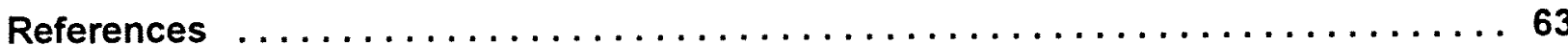




\section{List of tables}

Table 3.1: $\quad$ Overview of material costs

Table 3.2: Fictitious example: Costs of one day suspension of harbour operations

Table 3.3: Fictitious example: Total costs in case of failure of the breakwater

Table 4.1: Overview of breakwater properties (base case)

Table 5.1: Geometry and cost data used in the optimization

Table 5.2: $\quad$ Overview of random variables and distribution functions

Table 5.3: Input and results for four interest rates and three lifetimes

Table 5.4: Input and results for optimization with two random variables

Table 5.5: Input and results for optimization including wave transmission

\section{List of figures}

Figure 2.1: Example fault tree with top event and two failure modes

Figure 2.2: $\quad$ Overview of final failure modes (taken from [de Groot et al., 1996])

Figure 2.3: Overview of preceding failure modes (taken from [de Groot et al., 1996])

Figure 2.4: Fault tree of a vertical breakwater (mechanisms used in chapter 4 and 5 printed in bold)

Figure 3.1: Breakwater cross section with cost components

Figure 3.2: Parts of the caisson cross section

Figure 4.1: Overview of the breakwater properties (base case)

Figure 4.2: Ratio $\mathrm{H}_{\mathrm{d} ; \max } / \mathrm{h}_{\mathrm{s}}$ as a function of the wave period and the water depth

Figure 4.3: Forces on the caisson (hydrostatic approach)

Figure 4.4: Forces on the caisson (linear wave theory)

Figure 4.5: Definition sketch

Figure 4.6: Wave forces according to [Goda, 1985]

Figure 4.7: Horizontal force on the caisson calculated with three different wave load models (Base case, $\mathrm{T}=8 \mathrm{~s}$ )

Figure 4.8: Horizontal force on the caisson calculated with three different wave load models (Mound height raised $10 \mathrm{~m}$ with respect to the base case, $\mathrm{T}=8 \mathrm{~s}$ )

Figure 4.9: Possible distributions of the effective soil stress under a caisson

Figure 4.10: Example of required caisson width per mechanism as a function of the design wave height with hydrostatic approach of wave forces $\left(h_{c}=17 \mathrm{~m}\right)$

Figure 4.11: Required caisson width as a function of the crest height with hydrostatic approach for the wave forces $\left(\mathrm{H}_{\mathrm{d}}=10 \mathrm{~m}\right)$

Figure 4.12: Area of the caisson cross section for several wave heights (water depth $15 \mathrm{~m}$, hydrostatic approach)

Figure 4.13: Area of the caisson cross section for several wave heights (water depth $15 \mathrm{~m}, \mathrm{~T}=8 \mathrm{~s}$, linear wave theory)

Figure 4.14: Area of the caisson cross section for several wave heights (water depth $15 \mathrm{~m}, \mathrm{~T}=12 \mathrm{~s}$, linear wave theory) 


\section{List of figures (continued)}

Figure 4.15: Area of the caisson cross section for several wave heights (water depth $15 \mathrm{~m}, \mathrm{~T}=8 \mathrm{~s}$, Goda method for wave forces)

Figure 4.16: Area of the caisson cross section for several wave heights (water depth $15 \mathrm{~m}, \mathrm{~T}=12 \mathrm{~s}$, Goda method for wave forces)

Figure 5.1: Probability densities of significant wave height and design wave height

Figure 5.2: Probability densities of the water depth in front of the caisson

Figure 5.3: Significant wave height in the harbour as a function of the wave height outside (crest height of the breakwater: $2 \mathrm{~m}$ )

Figure 5.4: Design wave height at which collapse of the caisson occurs (ultimate wave height)

Figure 5.5: Probability of caisson failure as a function of width and height of the caisson

Figure 5.6: Total lifetime costs as a function of height and width of the caisson (base case)

Figure 5.7: Optimal height and width of the caisson (run 1 through 4)

Figure 5.8: Cost per metre width or height of the caisson

Figure 5.9: Individual failure probabilities of failure (run 1 through 4)

Figure 5.10: Optimal height and width of the caisson (run 2 and 7)

Figure 5.11: Individual failure probabilities (run 2 and 7)

Figure 5.12: Optimal height and width of the caisson (run 2, 8 and 9)

Figure 5.13: Individual failure probabilities (run 2, 8 and 9)

\section{List of annexes}

Annex 1: $\quad$ Design rules for vertical breakwaters derived by PIANC

Annex II: Determination of the relevant pressure distributions under the caisson

Annex III: Description of the program OPT_VBW

Annex IV: Overview of input and output for all calculations

Annex V: Comparison of numerical and analytical results

Annex VI: Numerical results for four interest rates

Annex VII: Numerical results for three life times

Annex VIII: Numerical results for two random variables

Annex IX: Numerical results including transmission 


\section{List of symbols}

\begin{tabular}{|c|c|c|}
\hline Symbol & SI-unity & Description \\
\hline $\mathrm{A}_{\mathrm{c}}$ & $\mathrm{m}^{2}$ & Area of the caisson cross section \\
\hline $\mathrm{B}_{\mathrm{b}}$ & $\mathrm{m}$ & Width of the berm on the front side of the breakwater \\
\hline $\mathrm{B}_{\mathrm{b} ; \text { back }}$ & m & Width of the berm on the back side of the breakwater \\
\hline $\mathrm{B}_{\mathrm{c}}$ & $\mathrm{m}$ & Width of the caisson \\
\hline $\mathrm{B}_{\mathrm{cmax}}$ & $\mathrm{m}$ & $\begin{array}{l}\text { Caisson width required to prevent exceedance of the maximum effective } \\
\text { soil stress on the harbour side }\end{array}$ \\
\hline $\mathrm{B}_{\mathrm{cmin}}$ & $\mathrm{m}$ & Caisson width required to keep soil on sea side under pressure \\
\hline $\mathrm{B}_{\text {cslid }}$ & $\mathrm{m}$ & Caisson width required to prevent sliding \\
\hline $\mathrm{C}_{\text {lifetime }}$ & $\$$ & Total costs in the lifetime of the structure \\
\hline $\mathrm{C}_{\mathrm{SLS}}$ & $\$ /$ day & Costs per day in case of serviceability failure \\
\hline $\mathrm{C}_{\mathrm{ULS}}$ & $\$$ & Costs in case of collapse of the structure \\
\hline $\mathrm{d}$ & $\mathrm{m}$ & Depth in front of the caisson \\
\hline$d_{c}$ & $\mathrm{~m}$ & Height of rubble foundation with respect to the bottom of the caisson \\
\hline$d_{\text {cap }}$ & $\mathrm{m}$ & Thickness of concrete cap \\
\hline $\mathrm{d}_{\text {daily }}$ & $\mathrm{m}$ & Daily maximum water depth in front of the caisson \\
\hline$d_{\text {floor }}$ & $\mathrm{m}$ & Thickness of concrete floor \\
\hline $\mathrm{d}_{\text {yearly }}$ & $\mathrm{m}$ & Yearly maximum water depth in front of the caisson \\
\hline $\mathrm{f}$ & - & Friction coefficient \\
\hline$F_{1}$ & $\mathrm{kN} / \mathrm{m}$ & Horizontal force caused by wave pressure above still water level \\
\hline $\mathrm{F}_{2}$ & $\mathrm{kN} / \mathrm{m}$ & Horizontal force cause by wave pressure below still water level \\
\hline $\mathrm{F}_{\mathrm{R}}$ & $\mathrm{kN} / \mathrm{m}$ & Force representing the strength of the structure \\
\hline $\mathrm{F}_{\mathrm{S}}$ & $\mathrm{kN} / \mathrm{m}$ & Force representing the load on the structure \\
\hline $\mathrm{F}_{\mathrm{u}}$ & $\mathrm{kN} / \mathrm{m}$ & Uplift force \\
\hline $\mathrm{F}_{\underline{\underline{x}}}(\xi)$ & - & Cumulative distribution function of random variable $\mathrm{x}$ \\
\hline g & $\%$ & Rate of economical growth \\
\hline $\mathrm{G}(\mathrm{A}, \mathrm{B})$ & - & Gumbel distribution with parameters A and B \\
\hline$h_{b}$ & $\mathrm{~m}$ & Height of the rubble foundation with respect to the seabed \\
\hline$h_{c}$ & m & Height of the caisson \\
\hline
\end{tabular}




\begin{tabular}{|c|c|c|}
\hline Symbol & SI-unity & Description \\
\hline $\mathrm{H}_{\mathrm{d}}$ & m & Design wave height (individual wave) \\
\hline $\mathrm{H}_{\mathrm{d}}$ & $\mathrm{m}$ & Individual design wave height \\
\hline $\mathrm{H}_{\mathrm{d} ; \max }$ & $\mathrm{m}$ & Maximum possible individual wave height in front of a reflective structure \\
\hline $\mathrm{H}_{\text {refl }}$ & $\mathrm{m}$ & Maximum individual height of a reflected wave \\
\hline$h_{s}$ & $\mathrm{~m}$ & Depth in front of the breakwater \\
\hline $\mathrm{H}_{\mathrm{s} ; \mathrm{acc}}$ & $\mathrm{m}$ & Acceptable significant wave height in the harbour basin \\
\hline $\mathrm{H}_{\mathrm{s} ; \mathrm{basin}}$ & $m$ & Significant wave height in the harbour basin \\
\hline $\mathrm{H}_{\mathrm{s} ; \text { daily }}$ & $\mathrm{m}$ & Daily maximum significant wave height \\
\hline $\mathrm{H}_{\mathrm{s} ; \mathrm{out}}$ & $\mathrm{m}$ & Significant wave height outside the harbour basin \\
\hline $\mathrm{H}_{\mathrm{s}, \mathrm{yearty}}$ & $\mathrm{m}$ & Yearly maximum significant wave height \\
\hline $\mathrm{I}_{0}$ & $\$ / m$ & Project costs (surveying, design etc.) \\
\hline$I_{\text {concr }}$ & $\$ / m^{3}$ & Costs of concrete \\
\hline$I_{\text {constr }}$ & $\$$ & Total construction costs \\
\hline$I_{\text {sand }}$ & $\$ / m^{3}$ & Costs of sand \\
\hline k & - & Wave number \\
\hline $\mathrm{K}_{\mathrm{t}}$ & - & Transmission coefficient \\
\hline L & $\mathrm{m}$ & Wave length \\
\hline $1_{1}$ & $\mathrm{~m}$ & Lever arm of horizontal force above still water level \\
\hline$l_{2}$ & $\mathrm{~m}$ & Lever arm of horizontal force below still water level \\
\hline $\mathrm{L}_{\text {brwt }}$ & m & Total length of the breakwater \\
\hline $1_{u}$ & m & Lever arm of uplift force \\
\hline $\mathrm{m}$ & - & $\begin{array}{l}\text { Cotangent of the slope of the rubble foundation on the back side of the } \\
\text { breakwater }\end{array}$ \\
\hline $\mathrm{M}_{\mathrm{H}}$ & $\mathrm{kNm} / \mathrm{m}$ & Tilting moment due to horizontal forces \\
\hline $\mathrm{M}_{\mathrm{V}}$ & $\mathrm{kNm} / \mathrm{m}$ & Tilting moment due to vertical forces \\
\hline$\Sigma \mathrm{M}$ & $\mathrm{kNm} / \mathrm{m}$ & Total tilting moment of the loads on the caisson \\
\hline $\mathrm{n}$ & - & $\begin{array}{l}\text { Cotangent of the slope of the rubble foundation on the front side of the } \\
\text { breakwater }\end{array}$ \\
\hline $\mathrm{N}$ & year & Lifetime of the structure \\
\hline$N(A, B)$ & - & Gaussian distribution with parameters $\mathrm{A}$ and $\mathrm{B}$ \\
\hline
\end{tabular}




\begin{tabular}{|c|c|c|}
\hline Symbol & Sl-unity & Description \\
\hline $\mathrm{p}$ & $\%$ & $\begin{array}{l}\text { Percentage of concrete in the breakwater cross section between cap and } \\
\text { floor }\end{array}$ \\
\hline $\mathrm{p}(\mathrm{z})$ & $\mathrm{kN} / \mathrm{m}^{2}$ & $\begin{array}{l}\text { Pressure under a wave as a function of the depth under the still water } \\
\text { level }\end{array}$ \\
\hline $\mathrm{p}_{1}$ & $\mathrm{kN} / \mathrm{m}^{2}$ & Wave pressure at still water level \\
\hline $\mathrm{p}_{3}$ & $\mathrm{kN} / \mathrm{m}^{2}$ & Wave pressure at the toe of the caisson \\
\hline $\mathrm{p}_{4}$ & $\mathrm{kN} / \mathrm{m}^{2}$ & Wave pressure at the top of the caisson \\
\hline $\mathrm{p}_{\mathrm{dyn} ; \max }$ & $\mathrm{kN} / \mathrm{m}^{2}$ & $\begin{array}{l}\text { Maximum dynamic pressure under a wave (total pressure minus } \\
\text { hydrostatic pressure) }\end{array}$ \\
\hline$P_{f ; S L S}$ & 1/day & Probability of serviceability failure \\
\hline$P_{\mathrm{f} ; \mathrm{ULS}}$ & 1/year & Probability of collapse \\
\hline $\mathrm{P}_{\text {low }}$ & 1/year & Lower boundary of probability of failure (series system) \\
\hline$P_{\max }$ & 1/year & Probability of exceedance of maximum pressure on harbour side \\
\hline$P_{\min }$ & 1/year & Probability of failure due to mechanism "too low pressure on sea side" \\
\hline $\mathbf{P}_{\text {slid }}$ & 1/year & Probability of sliding failure \\
\hline$P_{\text {up }}$ & 1/year & Upper boundary of probability of failure (series system) \\
\hline $\mathrm{p}_{\mathrm{u}}$ & $\mathrm{kN} / \mathrm{m}^{2}$ & Uplift pressure at the toe of the caisson \\
\hline $\mathbf{r}$ & - & Reflection coefficient \\
\hline $\mathrm{R}$ & varies & Strength in reliability function (general) \\
\hline $\mathrm{R}_{\mathrm{c}}$ & $\mathrm{m}$ & Crest height of the caisson with respect to still water level \\
\hline $\mathrm{R}_{\text {lifetime }}$ & $\$$ & Total risk in the lifetime of the structure \\
\hline $\mathrm{R}_{\text {year }}$ & $\$$ & Risk in one year \\
\hline$r^{\prime}$ & $\%$ & Net interest rate \\
\hline S & varies & Load in reliability function (general) \\
\hline $\mathrm{T}$ & $s$ & Wave period \\
\hline$\Sigma \mathrm{V}$ & $\mathrm{kN} / \mathrm{m}$ & Total of the vertical loads on the caisson \\
\hline$V_{\text {concr }}$ & $m^{3}$ & Volume of concrete \\
\hline $\mathrm{V}_{\text {sand }}$ & $m^{3}$ & Volume of sand \\
\hline $\mathrm{W}_{\text {eff }}$ & $\mathrm{kN} / \mathrm{m}$ & Effective weight of the caisson (weight minus buoyancy) \\
\hline $\mathrm{z}$ & $\mathrm{m}$ & Depth under still water level \\
\hline
\end{tabular}




\begin{tabular}{|c|c|c|}
\hline Symbol & SI-unity & Description \\
\hline $\mathrm{Z}$ & varies & Reliability function \\
\hline$Z_{\max }$ & varies & Reliability function for exceedance of the maximum effective soil stress \\
\hline$Z_{\min }$ & varies & Reliability function for keeping soil on sea side under pressure \\
\hline$Z_{\text {slid }}$ & varies & Reliability function for sliding of the caisson \\
\hline $\mathrm{Z}_{\text {uLS }}$ & varies & Total reliability function for ultimate limit state \\
\hline$\alpha$ & - & Empirical factor in Goda's formula for wave transmission \\
\hline$\alpha_{1}$ & - & Empirical factor in Goda's formula for wave forces \\
\hline$a_{2}$ & - & Empirical factor in Goda's formula for wave forces \\
\hline$\alpha_{3}$ & - & Empirical factor in Goda's formula for wave forces \\
\hline$\beta$ & - & Empirical factor in Goda's formula for wave transmission \\
\hline$\beta$ & $\circ$ & Wave direction in Goda's formula for wave forces \\
\hline$\gamma_{\mathrm{c}}$ & $\mathrm{kN} / \mathrm{m}^{3}$ & Mean specific density of the caisson \\
\hline$\gamma_{\text {concr }}$ & $\mathrm{kN} / \mathrm{m}^{3}$ & Specific density of concrete \\
\hline$\gamma_{\mathrm{w}}$ & $\mathrm{kN} / \mathrm{m}^{3}$ & Specific density of water \\
\hline$\eta^{*}$ & $\mathrm{~m}$ & Maximum crest elevation of a wave in front of the caisson \\
\hline$\sigma$ & $\mathrm{kN} / \mathrm{m}^{2}$ & Effective soil stress \\
\hline$\sigma_{\text {harb }}$ & $\mathrm{kN} / \mathrm{m}^{2}$ & Effective soil stress on the harbour side of the caisson \\
\hline$\sigma_{\max }$ & $\mathrm{kN} / \mathrm{m}^{2}$ & Maximum allowable effective soil stress \\
\hline$\sigma_{\text {sea }}$ & $\mathrm{kN} / \mathrm{m}^{2}$ & Effective soil stress on the sea side of the caisson \\
\hline
\end{tabular}




\section{Introduction}

\section{$1.1 \quad$ General}

Breakwaters can be discerned in two main types:

- Rubble mound breakwaters, consisting of a large amount of quarry stone;

- Vertical faced breakwaters, consisting of a vertical wall founded on a relatively low bed of quarry stone.

The vertical type is very often built throughout history. After several major failures in the 1930's this design concept was largely abandoned, favouring the rubble mound type [Oumeraci, 1994]. A series of failures of rubble mound breakwaters in the 1970's and 1980's has led to a renewed interest in the vertical faced breakwater [Bijker et al, 1981; Edge et al., 1982].

\subsection{Optimal geometry of a breakwater structure}

A designer wants to choose the geometry of a structure, e.g a ratio of the width and height of a vertical breakwater in such a way that the total lifetime costs are minimized. For a given safety level it is possible to choose the width and height of the breakwater such that the construction costs are minimized. This is one of the simplest ways to optimize the design of a vertical breakwater. In practice however one has to determine the preferred level of safety.

In general there are two boundary conditions for the acceptable safety level:

- The individual accepted risk. The probability accepted by an individual to die in case of collapse of a structure;

- The societal accepted risk. The probability of occurrence of a certain number of casualties in case of collapse of a structure.

The above mentioned risk levels are upper limits for the probability of the loss of life due to failure of a structure. In the case of a breakwater without amenities the probability of loss of life due to failure is very small, but the economic losses can be severe. Therefore an economical point of view for optimizing the structures design is suitable [van Dantzig et al., 1960; Burcharth, 1995; Vrijling et al., 1995; Vrijling 1997].

\subsection{Objective of the study and working method}

Once the choice has been made to define the acceptable probability of failure using the economic point of view, a workable way to carry out the optimization has to be found. This study is concerned with the development of an optimization framework. Three steps can be discerned in this development. 
In principle the function to be minimized is given as (more details are given in chapter 3 ):

$$
\text { Lifetime costs }=\text { Construction costs }+ \text { Risk } k_{\text {Ultimate Limit State }}+\text { Risk } k_{\text {Serviceability Limit State }}
$$

In the first step only the construction costs are taken into account. Omitting the risk components of the cost function leads to an optimization of the breakwater geometry for a given safety level. In the second step the construction costs and the risk due to ultimate limit state failure are taken into account. In the third step excessive wave transmission is included to account for serviceability limit state failure.

\subsection{Outline of the report}

The rest of this report can be summarized as follows. Chapter 2 provides an overview of the functional requirements and the relevant failure modes of a vertical breakwater. In this chapter the main function of the breakwater is defined and a short fault tree is given.

Chapter 3 deals with costs of construction and failure. The complete cost function describing the lifetime costs as a function of caisson width and height is introduced. This chapter ends with an example of costs in the case of failure. This example will be used as input in the calculations of chapter 5.

Optimization of the breakwater geometry for a given safety level (minimization of the construction costs) is introduced in chapter 4. Formulae are derived to calculate the necessary caisson width as a function of design wave height and chosen caisson width. These formulae are used to calculate the optimal caisson geometry. Only ultimate limit state failure is considered in this chapter.

In chapter 5 the risk components are included in the optimization procedure. First only risk due to ultimate limit state failure is considered. Secondly risk due to serviceability limit state failure is included and the results are compared to the case with ULS only. Both optimizations are carried out with one and two random variables respectively.

Chapter 6 gives the conclusions drawn from this study. This chapter ends with an overview of future work which is considered necessary to improve the model.

Annex I describes the design rules for vertical breakwaters given by [PIANC, 1976]. Annex II gives some detailed calculations concerning the distributions of effective soil stress under a caisson. Annex III describes the properties of the numerical optimization model. In annex IV an overview is given of the input and output of the calculations which are made with the model. The comparison of the numerical and analytical results is shown in annex V. Annex IV through IX contain graphs of the numerical results. 


\section{Functional requirements and failure modes of a vertical breakwater}

\subsection{Introduction}

In this chapter the most important functions and failure modes of a breakwater will be discussed. Not every function is of equal importance. To define failure of the breakwater, one function has to be defined as the main function. If the structure fails to fulfill this function, the structure is said to have failed. In a fault tree, this so called top event is put in the top of the tree (see figure 2.1). More complex structures like breakwaters can fail in several ways, called failure modes. An overview of the failure modes of a vertical breakwater is given in this chapter. The failure modes are classified according to [de Groot et al., 1996].

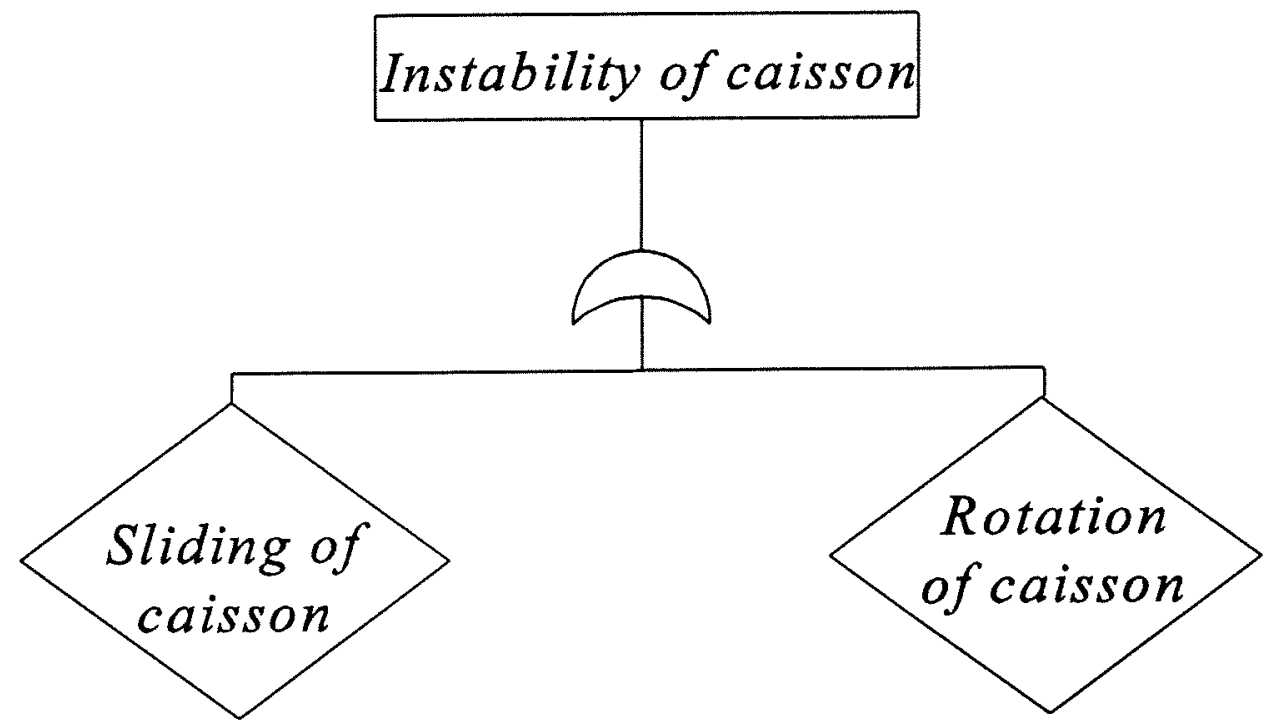

Figure 2.1: Example fault tree with top event and two failure modes

\subsection{Main function of the breakwater}

The main functions which can be allocated to a breakwater are:

- Protecting against wave action;

- Guiding (tidal) currents;

- Guiding sand transport and protecting against siltation.

Beside these main functions, a few secondary functions are possible, like:

- Providing mooring facilities for ships;

- $\quad$ Supporting loading facilities;

- Providing visual guidance for shipping;

- Providing recreational area. 
In this study the protection against wave action is considered the most important function. Other functions should be taken into account when designing a structure for actual cases, but are not considered in this study.

Considering the main function of a vertical breakwater the top event for a vertical breakwater is defined as:

$$
\text { "failure to provide sufficiently tranquil water". }
$$

In practice, sufficiently tranquil water is defined as the situation in which the significant wave height in the harbour basin does not exceed a certain acceptable height.

A few problems rise in relation to this definition:

- Wave disturbance influences different types of ships in different ways;

- Different harbour operations have a different acceptable wave height;

- The sensitivity of a certain area of the harbour basin to wave action depends on its function and on its location with respect to the breakwater;

- The ship response is in principle determined by the wave spectrum inside the harbour basin. It is very difficult to derive the spectrum inside the harbour from the spectrum on the sea side of the breakwater. The spectrum inside the harbour is a result of highly non-linear processes like diffraction through the entrance channel and wave transmission due to overtopping of the breakwater.

Despite these disadvantages, the simple definition will be used in this study. There are a few reasons to do this:

- The simple definition is easy to use;

- The aim of this study is to develop a framework for optimization, in which a better definition could be implemented later.

Therefore, the top event for a vertical breakwater is written as:

$$
\mathrm{H}_{\mathrm{s} ; \mathrm{basin}}>\mathrm{H}_{\mathrm{s} ; \mathrm{acc}}
$$

\subsection{Failure mechanisms of the breakwater}

The failure mechanisms of a vertical breakwater are discerned into two types [de Groot et al., 1996]:

- Final failure modes;

- Preceding failure modes.

Final failure modes are those failure modes which lead directly to the top event (for instance severe overtopping). Preceding failure modes do not lead directly to the top event, but bring the structure in a dangerous state or induce a final failure mode (for instance erosion of the seabed in front of the rubble foundation). 
Failure conditions are not failure modes, but induce failure modes to occur (for instance high wave load).

The final failure modes cause failure of the structure (figure 2.2). The final failure modes are:

- $\quad$ Sliding of the structure over the foundation;

- Bearing capacity failure of the foundation;

- Disintegration of (a part of) the structure;

- Settlement due to densification of the foundation soil or internal erosion;

- Overtopping or wave transmission.

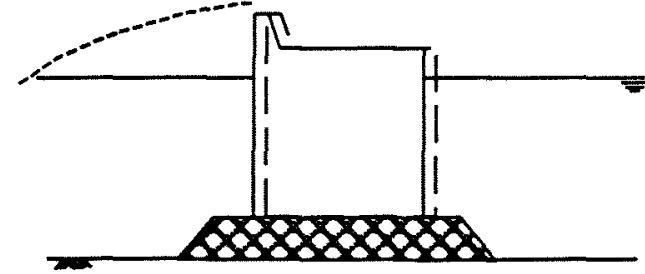

Sliding of structure over foundation

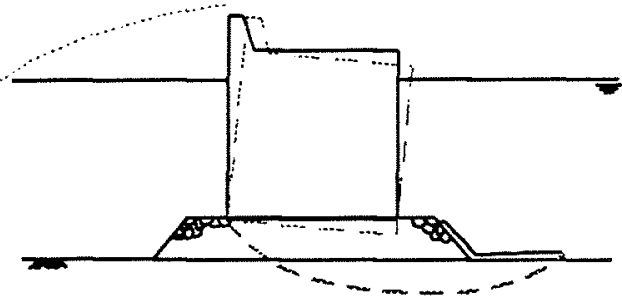

Bearing capacity failure of foundation (shoreward)

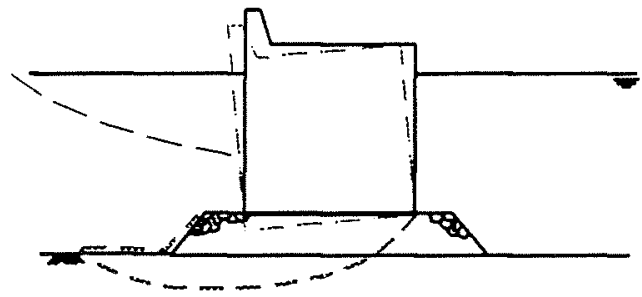

Bearing capacity failure of foundation (seaward)

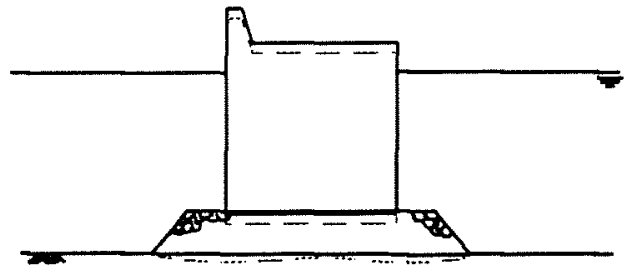

Settlement due to densification of foundation soil or internal erosion

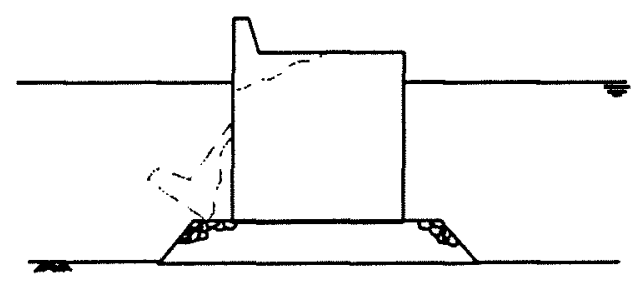

Desintegration of (part of) the structure

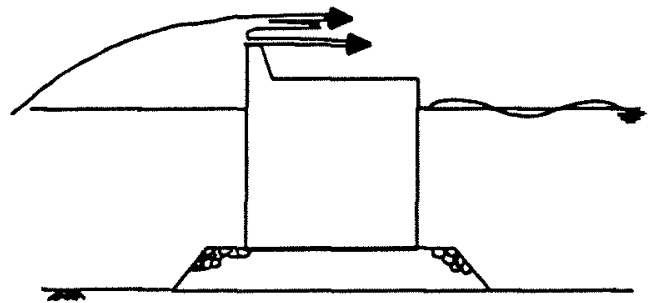

Overtopping during construction or at completion

Figure 2.2: $\quad$ Ovenview of final failure modes (taken from [de Groot et al., 1996]) 
The preceding failure modes bring the structure in a dangerous state or cause (eventually) the occurrence of a final failure mode (see figure 2.3). The preceding failure modes are:

- Erosion of the rubble foundation;

- Erosion of the seabed at toe or rubble foundation;

- Internal erosion of rubble foundation or subsoil;

- Loss of caisson fill after disintegration of caisson.

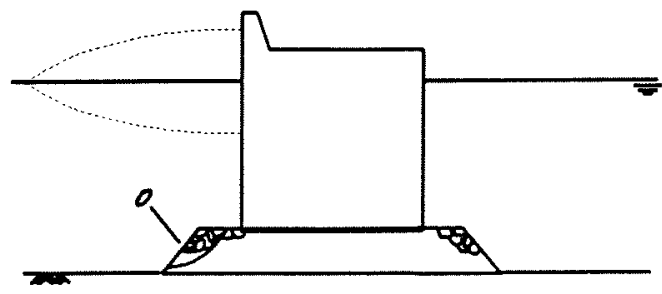

Erosion of rubble foundation

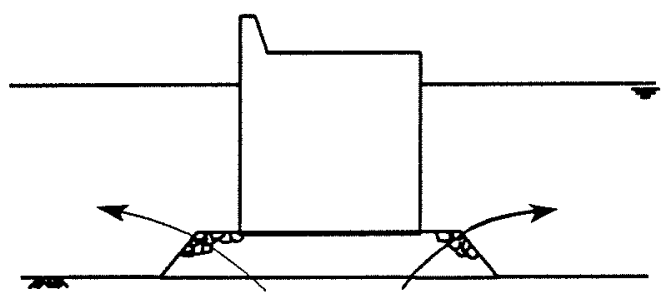

Internal erosion of rubble foundation or subsoil

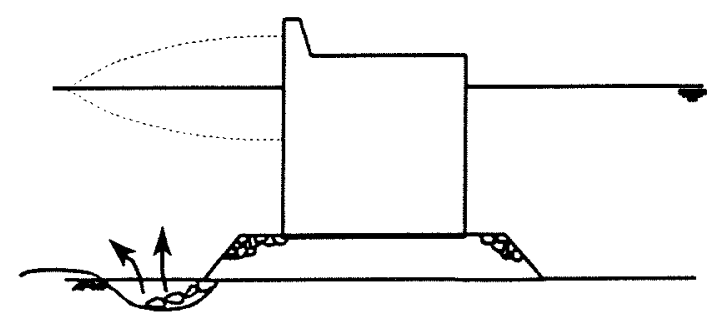

Erosion of the seabed near rubble foundation

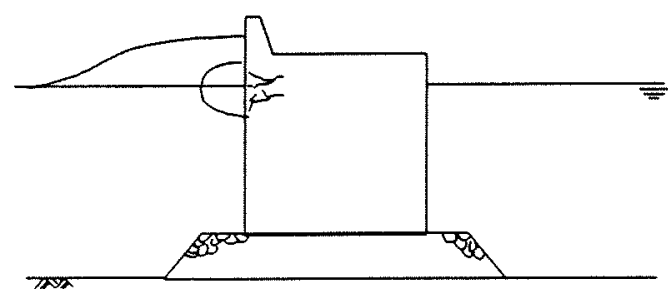

Loss of caisson fill after desintegration of front

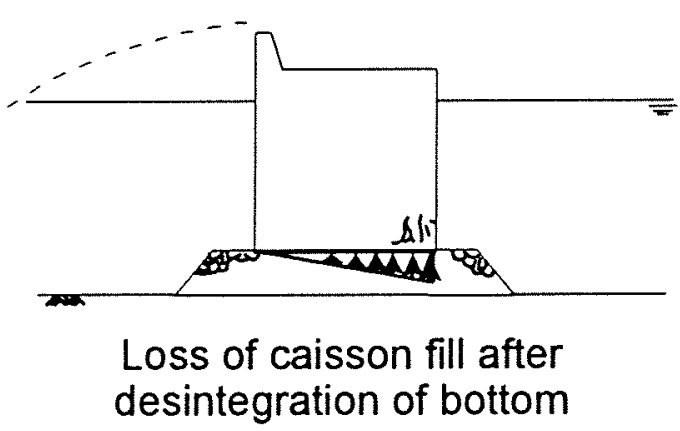

Figure 2.3: $\quad$ Overview of preceding failure modes (taken from [de Groot et al., 1996]) 
Failure conditions are loads or load effects. These cause preceding or final failure modes to occur. The failure conditions are:

- High wave load to wall;

- High instantaneous pore pressure in foundation, including high uplift force;

- High residual pore pressures and/or degradation in the subsoil;

- High wave pressures along rubble foundation and seabed;

- High current velocities along rubble foundation and seabed.

A fault tree for the breakwater down to the level of the final failure modes is given in figure 2.4 . Failure modes which are used in the optimization calculations of chapter 4 and 5 are printed in bold.

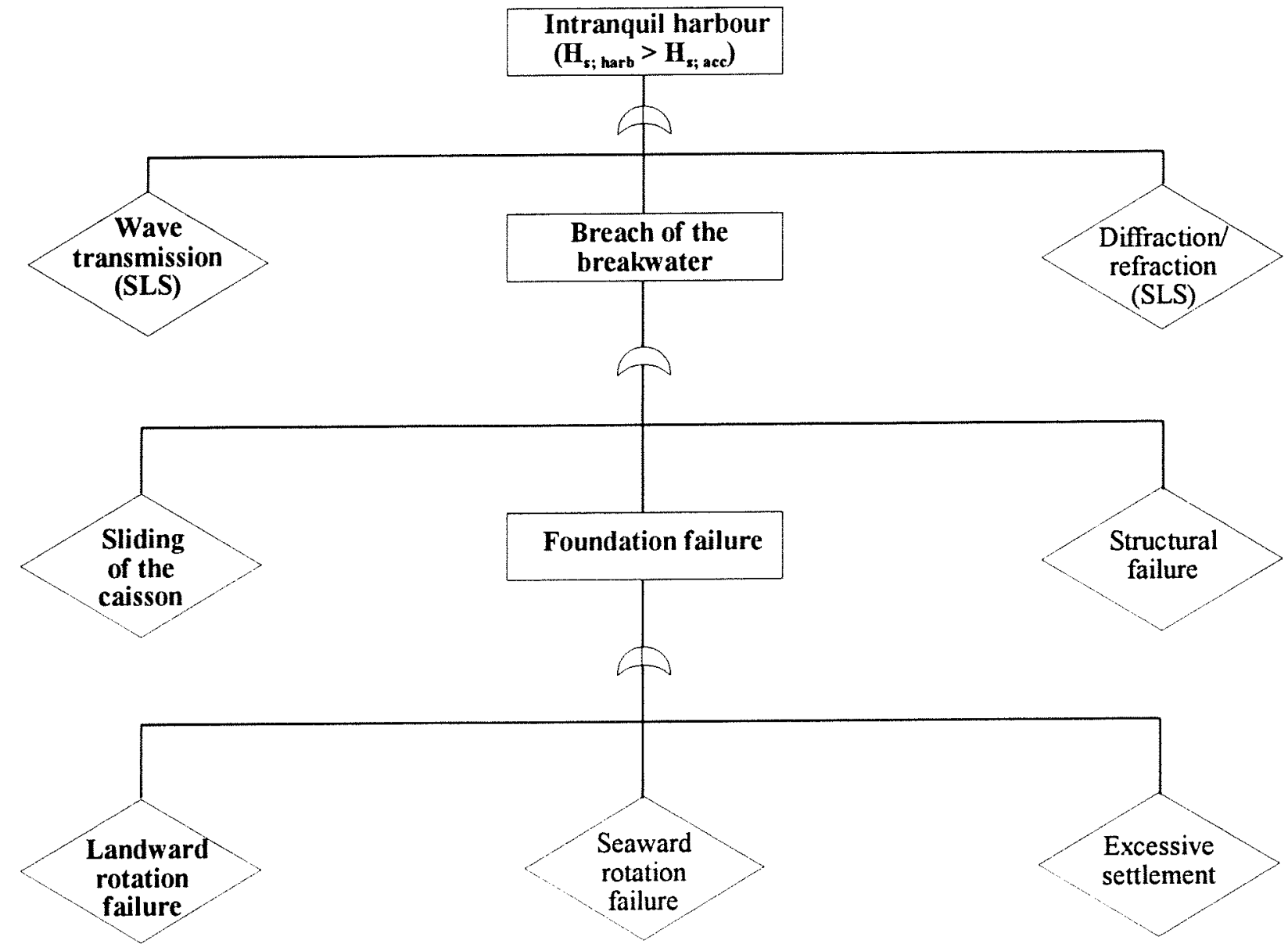

Figure 2.4: Fault tree of a vertical breakwater (mechanisms used in chapter 4 and 5 printed in bold). 



\section{Costs of construction and failure}

\subsection{Introduction}

To optimize a breakwater design the total lifetime costs have to be written as a function of the design variables. In this study the used design variables are the height and width of the caisson. The input for the cost function consists of estimates of the construction costs and the costs in case of failure.

The complete cost function is described in section 3.2. The estimates of the construction costs are given in section 3.3. Section 3.4 introduces the costs in case of failure.

\subsection{Total lifetime costs as a function of the design variables}

As stated in section 1.3, the lifetime costs consist of two main components:

- The construction costs;

- The risk.

The construction costs consist of a part which is a function of the breakwater geometry (variable costs) and a part which can only be allocated to the project as a whole (project costs). See section 3.3 for more details. For a breakwater caisson the variable costs can be assumed to be proportional to the volumes of concrete and filling sand in the cross section of the caisson. Therefore the construction costs can be written as:

$$
I_{\text {constr }}\left(h_{c}, B_{c}\right)=I_{0}+I_{\text {sand }} V_{\text {sand }}\left(h_{c}, B_{c}\right)+I_{\text {concr }} V_{\text {concr }}\left(h_{c}, B_{c}\right)
$$

In which:

$h_{c}$ : Height of the caisson [m];

$\mathrm{B}_{\mathrm{c}}$ : $\quad$ Width of the caisson [m];

$\mathrm{I}_{0}$ : $\quad$ Fixed costs [units];

$I_{\text {sand: }}$ Costs of filling sand [units $/ \mathrm{m}^{3}$ ];

$\mathrm{V}_{\text {sand }}$ : Volume of filling sand in the breakwater $\left[\mathrm{m}^{3}\right]$;

$I_{\text {concr: }}$ Costs of concrete [units $/ \mathrm{m}^{3}$ ];

$\mathrm{V}_{\text {concr: }}$ Volume of concrete in the breakwater $\left[\mathrm{m}^{3}\right]$. 
The yearly risk is defined as the expected value of the damage costs per year. In formula:

$$
\mathrm{R}_{\text {year }}\left(\mathrm{h}_{\mathrm{c}}, \mathrm{B}_{\mathrm{c}}\right)=365 \mathrm{P}_{\mathrm{f} ; \mathrm{SLS}}\left(\mathrm{h}_{\mathrm{c}}, \mathrm{B}_{\mathrm{c}}\right) \mathrm{C}_{\mathrm{SLS}}+\mathrm{P}_{\mathrm{f}, \mathrm{ULS}}\left(\mathrm{h}_{\mathrm{c}}, \mathrm{B}_{\mathrm{c}}\right) \mathrm{C}_{\mathrm{ULS}}\left(\mathrm{h}_{\mathrm{c}}, \mathrm{B}_{\mathrm{c}}\right)
$$

In which:

$\mathrm{P}_{\mathrm{f} ; \mathrm{SLS}}\left(\mathrm{h}_{\mathrm{c}}, \mathrm{B}_{\mathrm{c}}\right)$ : Probability of serviceability limit state failure per day as a function of the width and height of the caisson [1/day];

$\mathrm{C}_{\mathrm{SLS}}$ : $\quad$ Costs per day in case of serviceability limit state failure [units/day];

$\mathrm{P}_{\mathrm{f}, \mathrm{ULS}}\left(\mathrm{h}_{\mathrm{c}}, \mathrm{B}_{\mathrm{c}}\right)$ : Probability of ultimate limit state failure per year as a function of the width and height of the caisson [1/year];

$\mathrm{C}_{\mathrm{ULS}}\left(\mathrm{h}_{\mathrm{c}}, \mathrm{B}_{\mathrm{c}}\right)$ : Costs per event in case of ultimate limit state failure as a function of the width and height of the caisson [units/event].

The costs in case of ULS failure consist of replacement of (parts of) the breakwater and thus depend on the caisson dimensions. The costs in case of SLS failure are determined by the costs of downtime and thus are independent of the caisson geometry. See section 3.4 for more details.

The total risk over the lifetime of the structure is given by the sum of all yearly risks, corrected for interest, inflation and economical growth. This procedure is known as capitalization. In formula:

$$
R_{\text {lifetime }}\left(h_{c}, B_{c}\right)=\sum_{n=1}^{N} \frac{R_{\text {year }}\left(h_{c}, B_{c}\right)}{\left(1+r^{\prime}-g\right)^{n}}
$$

In which:

r': $\quad$ Net interest rate [\%];

g: Growth rate [\%].

The growth rate expresses that in general the value of all goods and equipment behind the breakwater will increase during the lifetime of the structure.

Following from (3.1), (3.2) and (3.3), the function which describes the lifetime costs can be written as:

$$
C_{\text {lifetime }}\left(h_{c}, B_{c}\right)=I_{\text {constr }}\left(h_{c}, B_{c}\right)+R_{\text {lifetime }}\left(h_{c}, B_{c}\right)
$$

Minimization of this function results in the optimal probability of failure and the optimal caisson dimensions simultaneously. 


\subsection{Costs of the breakwater construction}

\subsubsection{Costs related to the breakwater cross section}

When observing a breakwater cross section, several cost components can be discerned (figure 3.1).

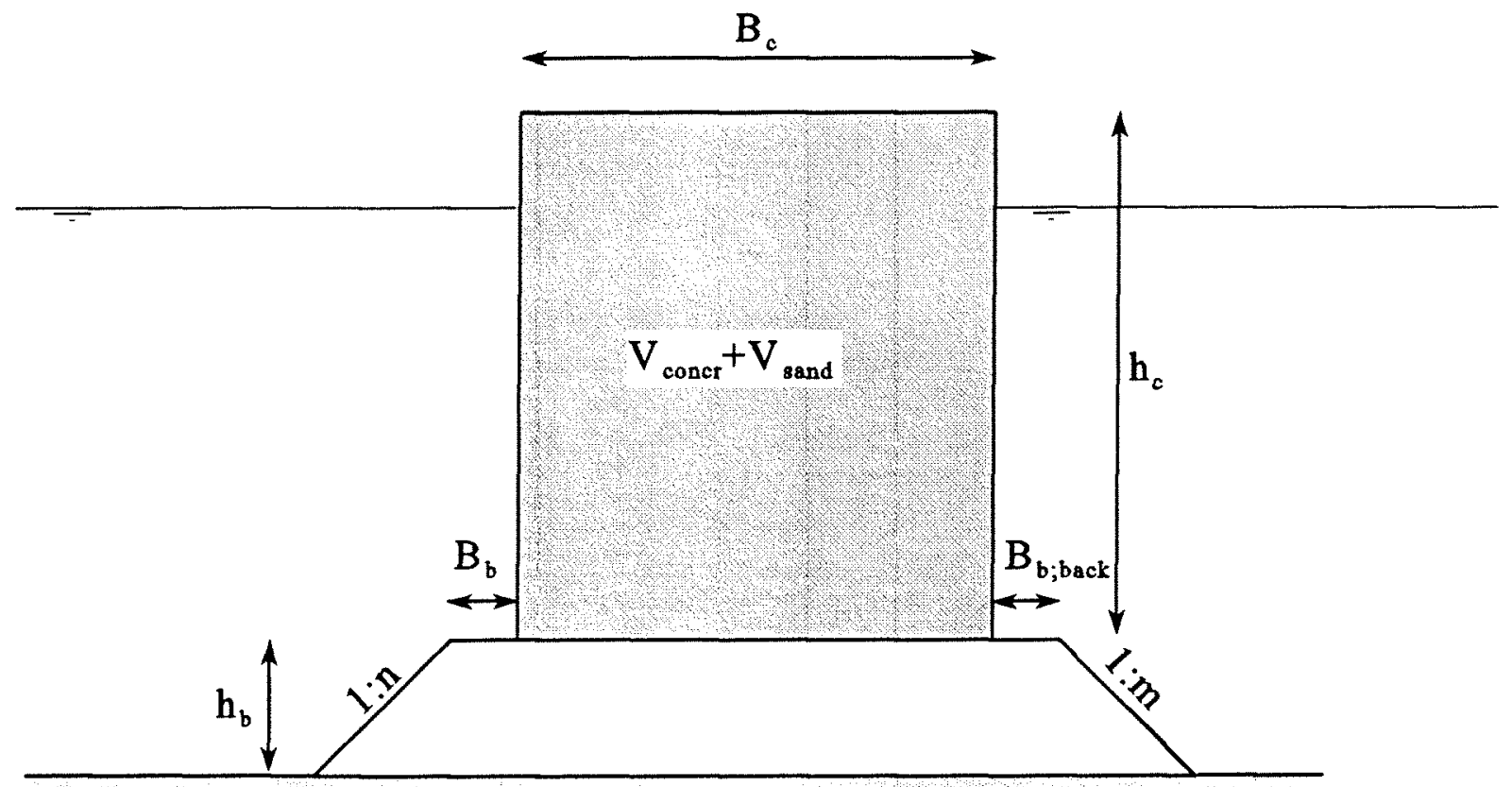

Figure 3.1: Breakwater cross section with cost components

The cross section consists of two main components; the caisson and the rubble foundation. In this study only the height and width of the caisson are used as design variables. Therefore the costs of the rubble foundation are omitted.

The costs of the caissons are in principle determined by:

- The volume of concrete in the caisson cross section: $\mathrm{V}_{\text {concri }}$;

- The volume of filling sand in the caisson cross section: $\mathrm{V}_{\text {sand; }}$;

- The total length of the breakwater: $\mathrm{L}_{\text {brwt }}$.

Usually, a breakwater caisson is equipped with dividing walls. The number of walls depends on the width of the caisson. When optimizing the breakwater design for the width of the caisson, the number of dividing walls is unknown. Therefore, volumes of concrete and filling sand are in principle unknown. This problem can be solved by assuming a fixed percentage of concrete in the caisson cross section in area A (see figure 3.2). The thickness (and thus the area) of the floor and concrete cap (areas $B$ and $C$ ) are set to fixed values. 


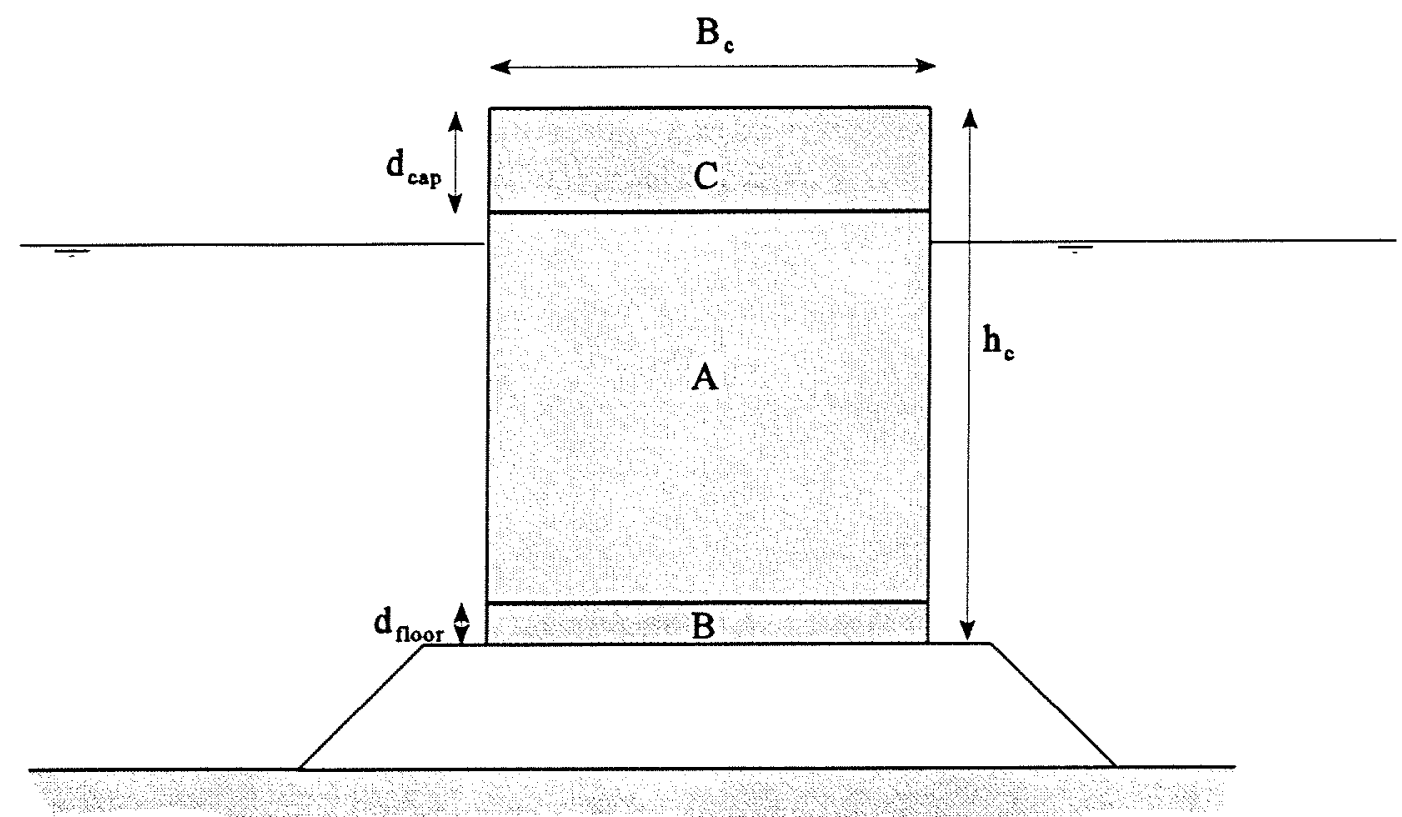

Figure 3.2: $\quad$ Parts of the caisson cross section

The volumes of concrete and filling sand can now be calculated in the following way:

$$
\begin{gathered}
V_{\text {concr }}=B_{c} L_{\text {brwt }}\left[\left\{\left(d_{\text {cap }}+d_{\text {floor }}\right)+p \cdot\left(h_{c}-d_{\text {cap }}-d_{\text {floor }}\right)\right\}\right] \\
V_{\text {sand }}=h_{c} \cdot B_{c} \cdot L_{\text {brwt }}-V_{\text {concr }}
\end{gathered}
$$

In which p denotes a fixed percentage of concrete.

In the calculations of chapter 5 the costs of concrete and sand as given in table 3.1 are used.

\begin{tabular}{|l|l|}
\hline Material & Price [US $\$ / \mathrm{m}^{3}$ ] \\
\hline Filling sand & 5 \\
\hline Concrete & 250 \\
\hline
\end{tabular}




\subsubsection{Costs related to the total project (project costs)}

Several cost components can not be allocated to the breakwater cross section, but only to the building project as a whole. Example of these cost components are:

- Costs of the feasibility study;

- Costs of the design of the breakwater;

- $\quad$ Site investigations, like penetration tests, borings and surveying;

- Administration.

These costs are included in the cost function by means of a fixed sum of money per metre breakwater $\left(\mathrm{I}_{0}\right.$ in equation 3.1).

\subsection{Costs related to failure of the breakwater}

\subsubsection{General}

In principle there are two ways in which a breakwater can fail. Either the breakwater collapses under survival conditions after which there will be more wave penetration in the protected area or the breakwater is too low and allows too much wave generation in the protected area due to overtopping waves. In both cases possibly harbour operations have to be stopped, resulting in damage (downtime costs).

\subsubsection{Damage due to interrupted harbour operations}

If a breakwater fails to protect the area of interest against wave action, possibly the operations in this area will have to be stopped. The damage costs which are caused by this interruption of harbour operations are called downtime costs. The exact amount of downtime costs is very difficult to determine. The downtime costs for one single ship can be found in literature (see for instance [DUT, 1995]), but the total damage in case of downtime does not depend solely on the downtime costs of ships. The size of the harbour and the type of cargo are also important variables in this type of damage. Furthermore, the availability of an alternative harbour is very important. If there is an alternative, ships will make use of this harbour. In that case the damaged harbour will lose income because less ships make use of the harbour and possibly because of claims of shipping companies. On a macro-economic scale however there is possibly minor damage since the goods are still coming in by way of the alternative harbour. This shows that also the availability of infrastructure in the area influences the damage in case of downtime. If an alternative harbour is not available the economic damage may be felt beyond the port itself.

The location of the breakwater in relation to the harbour also influences the damage costs. If the breakwater protects the entrance channel, the harbour can not be reached during severe storms, thus causing waiting times. These waiting times have the order of magnitude of hours to a few days. If the breakwater protects the harbour basin or a terminal damage to the breakwater can cause considerable amounts of extra downtime due to the fact that the structure only partly fulfills its task over a longer period of time. 


\subsubsection{Damage to the structure}

If the load on a structure component exceeds the admissible load, the component collapses. Several scenarios are now possible:

- The component is not essential to the functionality of the breakwater. Repair is not carried out and there is no damage in monetary terms. This is the case if, for instance, an armour block is displaced in the rubble foundation. It should be noted that this kind of damage can cause failure if a lot of armour blocks are displaced (preceding failure mode, see chapter 2);

- The component is essential to the functionality of the breakwater. The stability of the caissons is however not threatened. This is the case if, for instance, the crown wall collapses. The result is a reduction of the crest height of the breakwater which could threaten the functionality of the breakwater. Therefore repair has to be carried out and there is some damage in monetary terms;

- The caisson has become unstable during storm conditions. There is considerable damage to the breakwater, resulting in necessary replacement of (parts of) the breakwater. The damage in monetary terms is possibly even higher than the initial investment in the breakwater.

When optimizing a breakwater design an estimate of the damage is needed. In the case of a structure component this could be the cost of rebuilding. If large parts of the caissons are collapsed the area will have to be cleared before rebuilding the breakwater. In that case the damage will be higher than in the case of rebuilding alone. Furthermore, collapse will in general lead to downtime costs which further increases the damage.

\subsubsection{Fictitious example of damage costs}

The following examples have been taken from [Vrijling, 1997]. The costs are considered from the point of view of the harbour authorities (Port Trust, PT). The cost figures given in this section together with the material costs of section 3.3 .1 will be used in chapter 5 .

\begin{tabular}{|l|l|l|}
\hline Item & Description & Cost [US \$] \\
\hline Costs of shipping operation & $\begin{array}{l}\text { US \$ } 10000 \text { per vessel per day; average 1 } \\
\text { vessel per day; waiting 3 days extra }\end{array}$ & 30,000 \\
\hline Loss of income PT, direct & $\begin{array}{l}\text { Throughput } 19 \text { mln t/yr; } \\
\text { port dues US \$ 5.4/t }\end{array}$ & 280,000 \\
\hline Loss of income PT, indirect & Bad reputation per day & 140,000 \\
\hline Claims & Industry, shipping lines, other parties & 50,000 \\
\hline & SUBTOTAL & 500,000 \\
\hline $\begin{array}{l}\text { Multiplier for indirect } \\
\text { economic damage }\end{array}$ & 1.5 & 250,000 \\
\hline & TOTAL & 750,000 \\
\hline
\end{tabular}

Table 3.2: Fictitious example: Costs of one day suspension of harbour operations 


\begin{tabular}{|c|c|c|}
\hline Item & Description & $\begin{array}{l}\text { US \$ } \\
\text { million }\end{array}$ \\
\hline \multicolumn{3}{|l|}{ Structural damage } \\
\hline Damage to the breakwater & $20 \%$ of construction costs & 24 \\
\hline $\begin{array}{l}\text { Damage to other structures } \\
\text { in the harbour }\end{array}$ & Wharf, slope protection, harbour lights & 5 \\
\hline \multirow[t]{2}{*}{ Mobilization } & Lump sum & 4 \\
\hline & SUBTOTAL & 33 \\
\hline \multicolumn{3}{|l|}{ Economic damage } \\
\hline $\begin{array}{l}\text { Alternative transportation of } \\
\text { inputs to industry }\end{array}$ & $\begin{array}{l}\text { Throughput } 19 \mathrm{mln} \text { t/yr; } \\
\text { Extra transport costs per ton: US } \$ 6\end{array}$ & 114 \\
\hline Cost of shipping operation & $\begin{array}{l}\text { US } \$ 10,000 \text { per day; } \\
\text { average } 1 \text { vessel per day }\end{array}$ & 3.65 \\
\hline Loss of income PT, direct & $\begin{array}{l}\text { Throughput } 19 \mathrm{mln} \text { t/yr; } \\
\text { Lost port dues US } \$ 5.4 / \mathrm{t}\end{array}$ & 103 \\
\hline Loss of income PT, indirect & Bad reputation & 50 \\
\hline Lives lost & $<10$, economic damage negligible & - \\
\hline \multirow[t]{2}{*}{ Claims } & Industry, shipping, other parties & 100 \\
\hline & SUBTOTAL & 370 \\
\hline $\begin{array}{l}\text { Multiplier for indirect } \\
\text { economic damage }\end{array}$ & 1.5 & 555 \\
\hline \multicolumn{2}{|c|}{ Total structural and economic damage } & 588 \\
\hline
\end{tabular}

Table 3.3: Fictitious example: Total costs in case of failure of the breakwater 



\section{Minimization of the construction costs of a breakwater}

\subsection{Introduction}

The cost function introduced in chapter 3 consists of two main components:

- The construction costs;

- The capitalized risk.

If all environmental conditions are known as deterministic properties, the risk level is fixed and does not influence the optimal design. An optimal design can then be found by minimization of the function:

$$
I_{\text {constr }}\left(h_{c}, B_{c}\right)=I_{0}+I_{\text {sand }} V_{\text {sand }}\left(h_{c}, B_{c}\right)+I_{\text {concr }} V_{\text {concr }}\left(h_{c}, B_{c}\right)
$$

For reasons of efficiency, a constant specific density of the caisson is assumed. In that case the optimal design can be found by minimization of the area of the caisson cross section, given by:

$$
A_{c}\left(h_{c}, B_{c}\right)=h_{c} B_{c}
$$

This type of optimization is carried out for a fictitious breakwater, called the base case. The base case is introduced in section 4.2. Section 4.3 describes the calculation of the maximum design wave height in front of the structure. In section 4.4 three different wave load models for quasi static wave loads are introduced. In section 4.5 formulae are derived to calculate the necessary caisson width as a function of the wave forces and the caisson height. Optimal caisson dimensions for the three wave load models are derived in section 4.6. The results are compared to the design rules given by [PIANC, 1976] (see annex I). 


\subsection{Properties of the used breakwater, the base case}

The optimization procedure is tested on a chosen (fictitious) breakwater, called the base case. The base case consists of a square caisson, placed directly on the seabed. Note that in practice the caisson will be placed on a layer of rubble to prevent dangerous build up of water pressure in the soil under the caisson. Only caissons with the top at or above the still water level are considered. Lower caissons will never meet their functional requirements. The properties of the base case are given in figure 4.1 and table 4.1 .

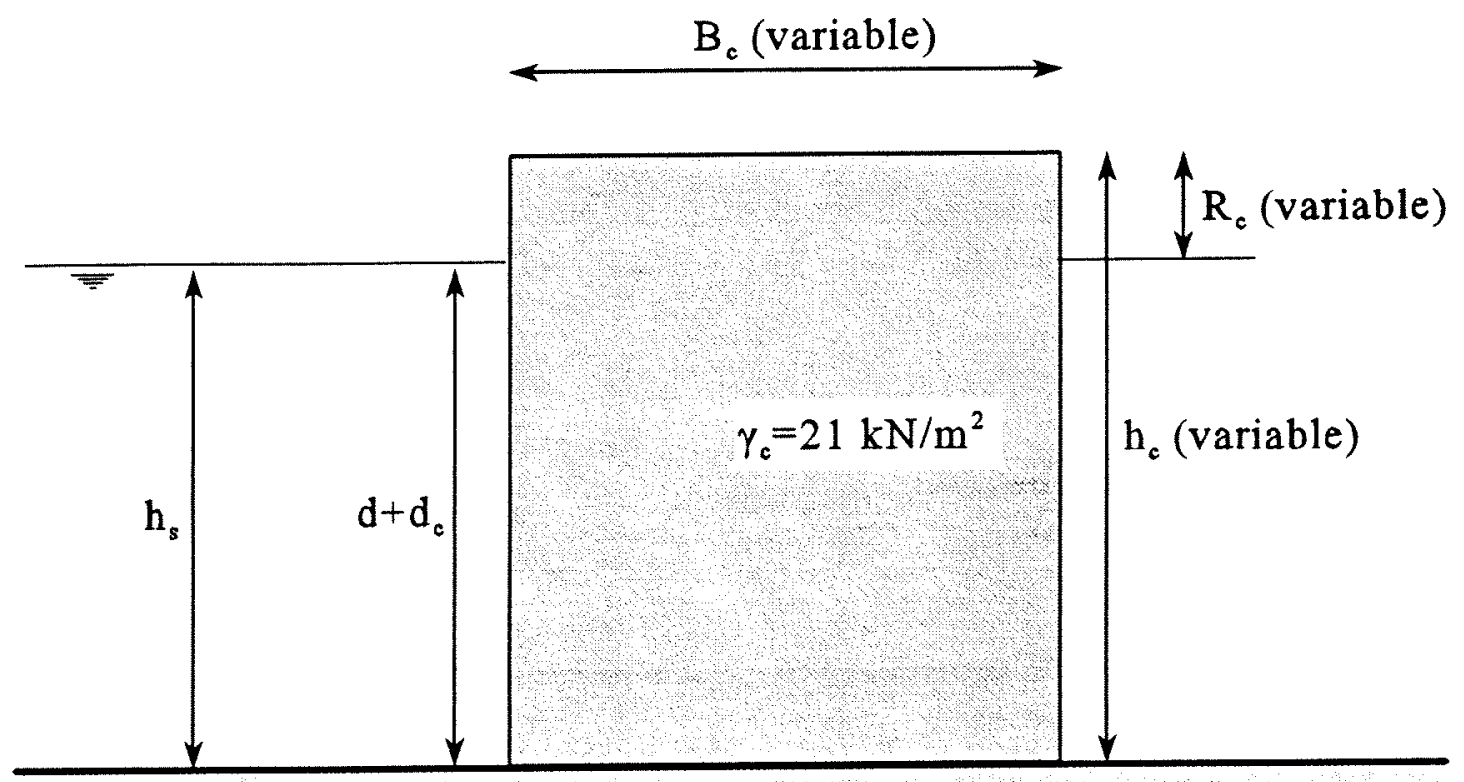

Figure 4.1: Overview of the breakwater properties (base case)

\begin{tabular}{|l|l|l|l|}
\hline Variable & Unit & Description & Value \\
\hline$h_{c}$ & $m$ & Height of caisson & $>d+d_{c}$ \\
\hline$B_{c}$ & $m$ & Width of caisson & variable \\
\hline$R_{c}$ & $m$ & Crest height with respect to SWL & variable \\
\hline$h_{s}$ & $m$ & Water depth in front of the breakwater & 15 \\
\hline$d$ & $m$ & Depth in front of the caisson & 15 \\
\hline$d_{c}$ & $m$ & Height of rubble foundation with respect to caisson bottom & 0 \\
\hline$r$ & - & Reflection coefficient & 1 \\
\hline$f$ & - & Friction coefficient & 0.36 \\
\hline$\gamma_{c}$ & $\mathrm{kN} / \mathrm{m}^{3}$ & Mean specific density of caisson & 21 \\
\hline$\gamma_{w}$ & $\mathrm{kN} / \mathrm{m}^{3}$ & Specific density of seawater & 10.25 \\
\hline$\sigma_{\max }$ & $\mathrm{kN} / \mathrm{m}^{2}$ & Maximum effective soil stress under the caisson & 500 \\
\hline
\end{tabular}

Table 4.1: Overview of breakwater properties (base case) 
Only the height and width of the caisson are used as design variables. All other variables are kept constant. The reflection coefficient is in fact influenced by wave transmission. The value chosen is an upper bound.

\subsection{Determination of the maximum design wave height}

To determine the maximum load on the structure, the maximum individual wave height in front of the structure has to be used. For a standing wave, Penney and Price proposed the following formula for the maximum height of a reflected wave [Wiegel, 1964]:

$$
\mathrm{H}_{\text {refl }}=0.22 \cdot \mathrm{L} \cdot \tanh \left(\frac{2 \pi \mathrm{h}_{\mathrm{s}}}{\mathrm{L}}\right)
$$

In which:

L: Wave length [m];

$h_{\mathrm{s}}$ : Water depth in front of the structure $[\mathrm{m}]$.

The height of the reflected wave is a function of the individual design wave height in front of the structure, written as:

$$
\mathrm{H}_{\mathrm{refl}}=(1+\mathrm{r}) \mathrm{H}_{\mathrm{d}}
$$

In which:

r: $\quad$ Reflection coefficient [-];

$\mathrm{H}_{\mathrm{d}}$ : Design wave height $[\mathrm{m}]$;

Substitution of (4.4) in (4.3) gives the maximum design wave height to be considered in the wave force calculation:

$$
H_{d ; \max }=\frac{0.22 L}{(1+r)} \tanh \left(\frac{2 \pi h_{s}}{L}\right)
$$

For a fully reflective breakwater the ratio between the maximum design wave height and the water depth in front of the structure is given as:

$$
\frac{\mathrm{H}_{\mathrm{d}, \max }}{\mathrm{h}_{\mathrm{s}}}=\frac{0.11 L \tanh \left(\frac{2 \pi \mathrm{h}_{\mathrm{s}}}{\mathrm{L}}\right)}{\mathrm{h}_{\mathrm{s}}}
$$

A contour plot of this function is given in figure 4.2 . 


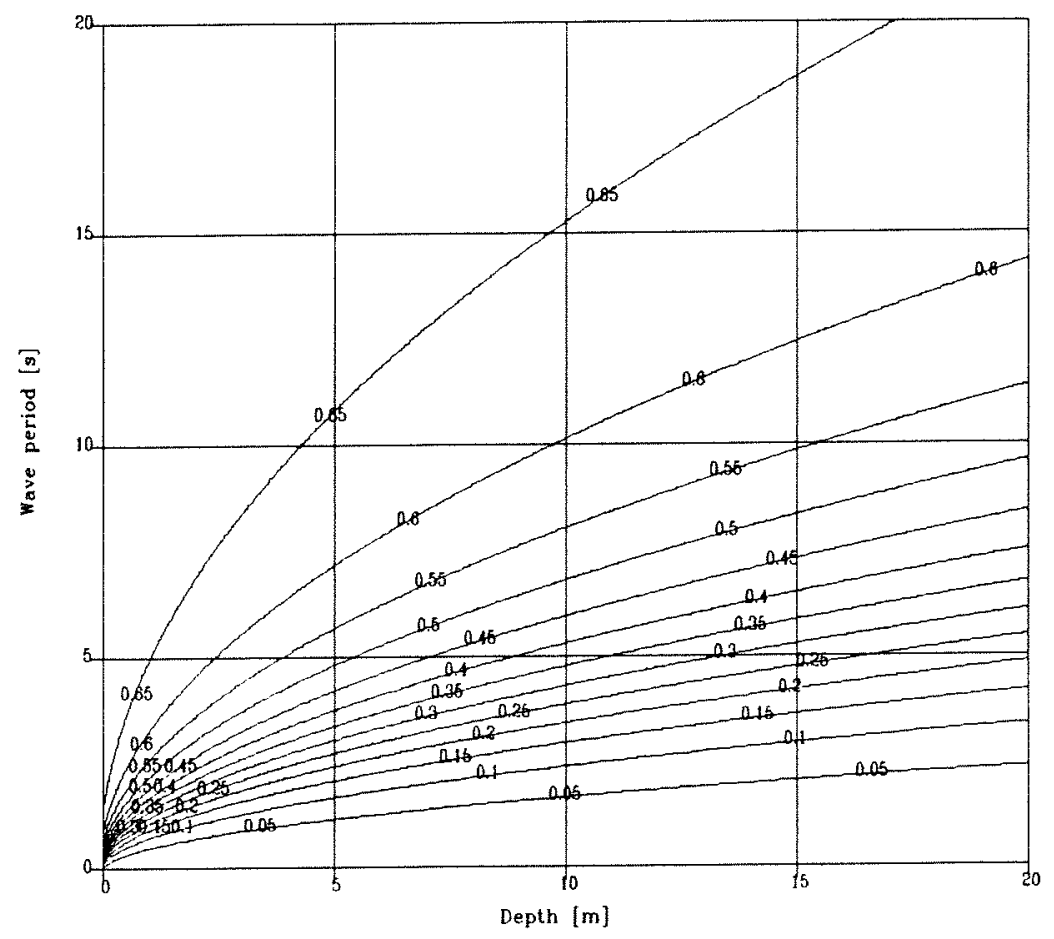

Figure 4.2: Ratio $\mathrm{H}_{\mathrm{d} ; \mathrm{max}} / \mathrm{h}_{\mathrm{s}}$ as a function of the wave period and the water depth

From this figure it can be seen that the maximum design wave height to be considered equals 65 $\%$ of the water depth. Every incoming wave which exceeds this height will not be able to cause a reflected wave which is higher than the physical possible maximum.

\subsection{Transfer functions for the wave load}

\subsubsection{General}

Transfer functions are used to determine the loads on the structure with the boundary conditions as input. In this section three models for the wave load are introduced. It should be noted that only quasi static wave loads are considered. The three wave load models are:

- Hydrostatic approach (section 4.4.2);

- Linear wave theory (section 4.4.3);

- Goda formula (section 4.4.4);

The three different approaches are used to gain insight in the influence of the load model on the optimum design of the breakwater (section 4.6). 


\subsubsection{Hydrostatic approach}

The wave loads are calculated by assuming a difference in still water level between the sea side and the harbour side of the breakwater (see figure 4.3).

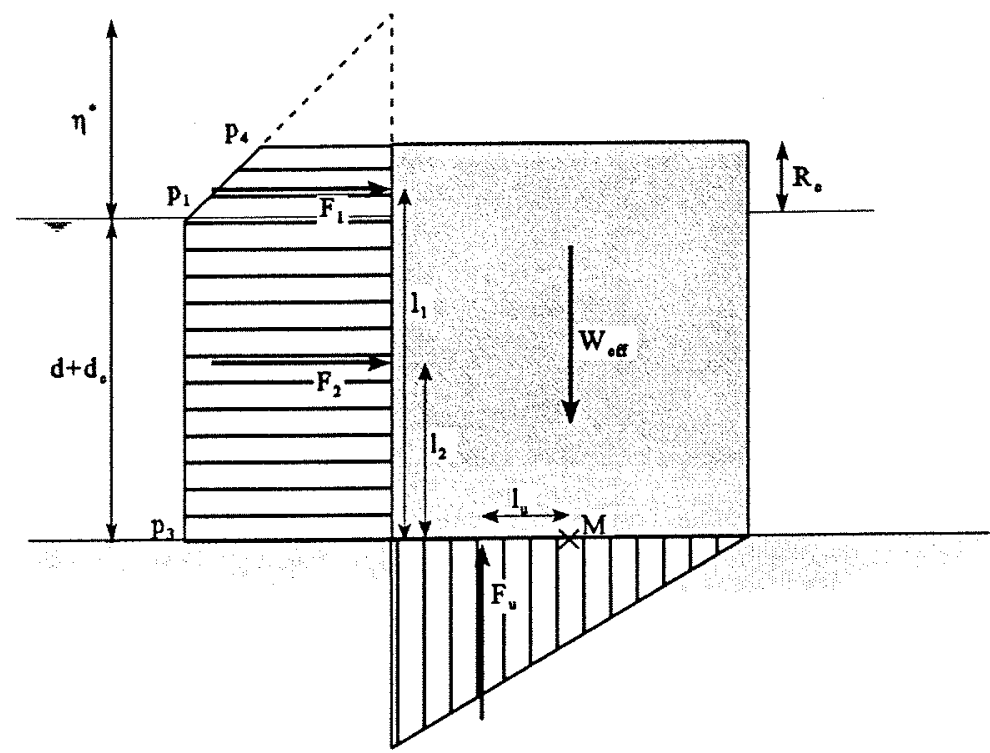

p.

Figure 4.3: Forces on the caisson (hydrostatic approach)

The head difference is taken equal to the crest elevation of the reflected wave and thus depends on the incident wave height and the reflection coefficient.

$$
\eta^{*}=\frac{1+r}{2} \cdot H_{d} \leq 0.11 L \tanh \left(\frac{2 \pi h_{s}}{L}\right)
$$

The direction of the waves is assumed to be head on. 
The wave pressures are given by:

$$
\begin{aligned}
& p_{1}=\gamma_{w} \eta^{*}=\gamma_{w} \frac{1+r}{2} H_{d} \\
& \mathrm{p}_{3}=\gamma_{\mathrm{w}} \eta^{*}=\gamma_{\mathrm{w}} \frac{1+\mathrm{r}}{2} \mathrm{H}_{\mathrm{d}} \\
& p_{4}= \begin{cases}{\left[1-\frac{R_{c}}{\eta^{*}}\right] p_{1}} & \text { for } 0 \leq R_{c} \leq \eta^{*} \\
0 & \text { for } R_{c}>\eta^{*}\end{cases} \\
& p_{u}=p_{3}
\end{aligned}
$$

In which:

$\gamma_{\mathrm{w}}$ : $\quad$ specific weight of the water $\left[\mathrm{kN} / \mathrm{m}^{3}\right]$;

$\eta^{*}: \quad$ crest elevation of the reflected wave in front of the structure [m];

$\mathrm{H}_{\mathrm{d}}$ : design wave height $[\mathrm{m}]$;

$r$ reflection coefficient [-];

$R_{c}$ : crest height of the caisson [m].

Using these pressures, the wave forces can be calculated:

$$
\begin{aligned}
& \mathrm{F}_{1}=\frac{1}{2}\left(\mathrm{p}_{1}+\mathrm{p}_{4}\right) \cdot \min \left\{\begin{array}{c}
\mathrm{R}_{\mathrm{c}} \\
\eta^{*}
\end{array}\right\} \\
& \mathrm{F}_{2}=\mathrm{p}_{1} \cdot\left(\mathrm{d}+\mathrm{d}_{\mathrm{c}}\right) \\
& \mathrm{F}_{\mathrm{u}}=\frac{1}{2} \mathrm{p}_{\mathrm{u}} \mathrm{B}_{\mathrm{c}}
\end{aligned}
$$

The lever arms of the individual forces are given by:

$$
\begin{aligned}
& l_{1}=d+d_{c}+\frac{\left(p_{1}+2 p_{4}\right) \cdot \min \left\{\begin{array}{c}
R_{c} \\
\eta^{*}
\end{array}\right\}}{3\left(2 p_{1}+p_{4}\right)} \\
& l_{2}=\frac{1}{2} \cdot\left(d+d_{c}\right) \\
& I_{u}=\frac{B_{c}}{6}
\end{aligned}
$$


Combining (4.9) and (4.10) gives the tilting moments on the caisson. The tilting moment due to the horizontal forces is given by:

$$
\mathrm{M}_{H}=1, \mathrm{~F}_{1}+1_{2} \mathrm{~F}_{2}
$$

And the moment of the vertical forces by:

$$
\mathrm{M}_{V}=1_{u} \mathrm{~F}_{u}=\frac{1}{12} \mathrm{p}_{u} \mathrm{~B}_{c}^{2}
$$

\subsubsection{Linear wave theory}

The linear wave theory (small amplitude wave theory) can be used to derive a formula for the pressure under a standing wave. See for instance [Dean et al., 1991].

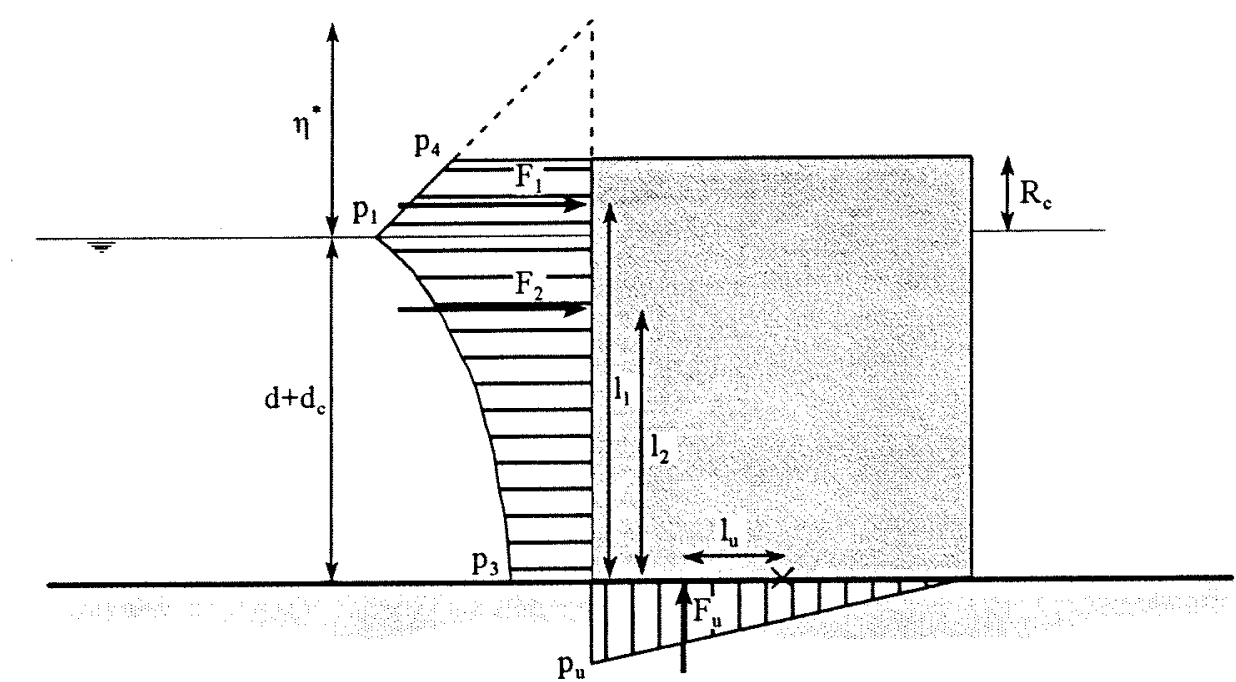

Figure 4.4: Forces on the caisson (linear wave theory)

The pressure below the water surface under a standing wave is in general given by:

$$
p(z)=-\gamma_{w} z+\gamma_{w} \eta^{*} \frac{\cosh k(h+z)}{\cosh k h} \cos (k x) \sin (\omega t)
$$

In which (see figure 4.5):

$z: \quad$ depth under still water level;

h: $\quad$ water depth;

$\eta^{*}: \quad$ crest elevation of the wave (eq. 4.2 );

k: $\quad$ wave number, defined as: $\frac{2 \pi x}{\mathrm{~L}}$;

$\omega: \quad$ angular frequency, defined as: $\frac{2 \pi t}{T}$. 


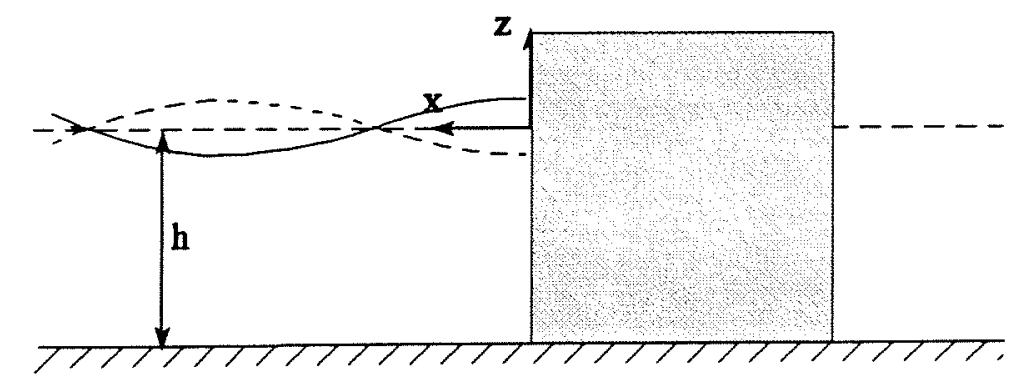

Figure 4.5: Definition sketch

The first term in equation 4.13 is the hydrostatic pressure. This (static) pressure is considered to be equal on both sides of the breakwater. The maximum dynamic pressure under the still water level just in front of the breakwater is given by $(x=0 ; t=(1 / 4+n) T, n=\ldots-1,0,1 \ldots)$ :

$$
p_{\text {dyn:max }}(z)=\gamma_{w} \eta^{*} \frac{\cosh k(h+z)}{\cosh k h}
$$

Assuming a hydrostatic pressure distribution above still water level, the wave forces acting on the caisson can be calculated (see figure 4.4).

The wave pressures are given by:

$$
\begin{aligned}
& p_{1}=\gamma_{w} \eta^{*} \\
& p_{3}=\frac{p_{1}}{\cosh \left(\frac{2 \pi}{L}\left(d+d_{c}\right)\right)} \\
& p_{4}= \begin{cases}\left(1-\frac{R_{c}}{\eta^{*}}\right) p_{1} & \text { for } 0 \leq R_{c} \leq \eta^{*} \\
0 & \text { for } R_{c}>\eta^{*}\end{cases} \\
& p_{u}=p_{3}
\end{aligned}
$$


Integration of the pressure distribution over the water depth results in the following formulae for the wave forces:

$$
\begin{aligned}
& F_{1}=\frac{1}{2} \min \left\{\begin{array}{c}
R_{c} \\
\eta^{*}
\end{array}\right\}\left(p_{1}+p_{4}\right) \\
& F_{2}=\int_{z=-d}^{0} p(z) d z=\frac{p_{1} \sinh \left(\frac{2 \pi}{L}\left(d+d_{c}\right)\right)}{\frac{2 \pi}{L} \cosh \left(\frac{2 \pi}{L}\left(d+d_{c}\right)\right)} \\
& F_{u}=\frac{1}{2} p_{u} B_{c}
\end{aligned}
$$

The lever arms with respect to the centre of the base plate are given by:

$$
\begin{aligned}
& l_{1}=d+d_{c}+\frac{\left(p_{1}+2 p_{4}\right) \cdot \min \left\{\begin{array}{c}
R_{c} \\
\eta^{*}
\end{array}\right\}}{3\left(2 p_{1}+p_{4}\right)} \\
& l_{2}=\left(d+d_{c}\right)+\frac{1-\cosh \left(\frac{2 \pi}{L}\left(d+d_{c}\right)\right)}{\frac{2 \pi}{L} \sinh \left(\frac{2 \pi}{L}\left(d+d_{c}\right)\right)} \\
& l_{u}=\frac{1}{6} B_{c}
\end{aligned}
$$

The tilting moment due to the horizontal forces is given by:

$$
\mathrm{M}_{\mathrm{H}}=1_{1} \mathrm{~F}_{1}+1_{2} \mathrm{~F}_{2}
$$

And the moment of the vertical forces by:

$$
M_{V}=1_{u} F_{u}=\frac{1}{12} p_{u} B_{c}^{2}
$$




\subsubsection{Goda's formula for wave forces}

When the water depth in front of the breakwater decreases, more and more waves tend to break in front of the caisson. This induces greater forces on the breakwater than predicted by linear wave theory. Goda derived a method to calculate wave forces including the effect of breaking waves [Goda, 1985]. The method was extended by Tanimoto et al. to include the effect of oblique wave attack [Goda, 1985] and by Takahashi et al. [Takahashi, 1996] to include the effect of impact forces. In this section the extension by Takahashi is not applied. This means that the method as described by [Goda, 1985] is used. To make possible a comparison with the hydrostatic approach and the linear wave theory, the angle of wave attack $(\beta)$ is set to zero (head on waves) and the design wave height $\mathrm{H}_{\mathrm{d}}$ is used as input.

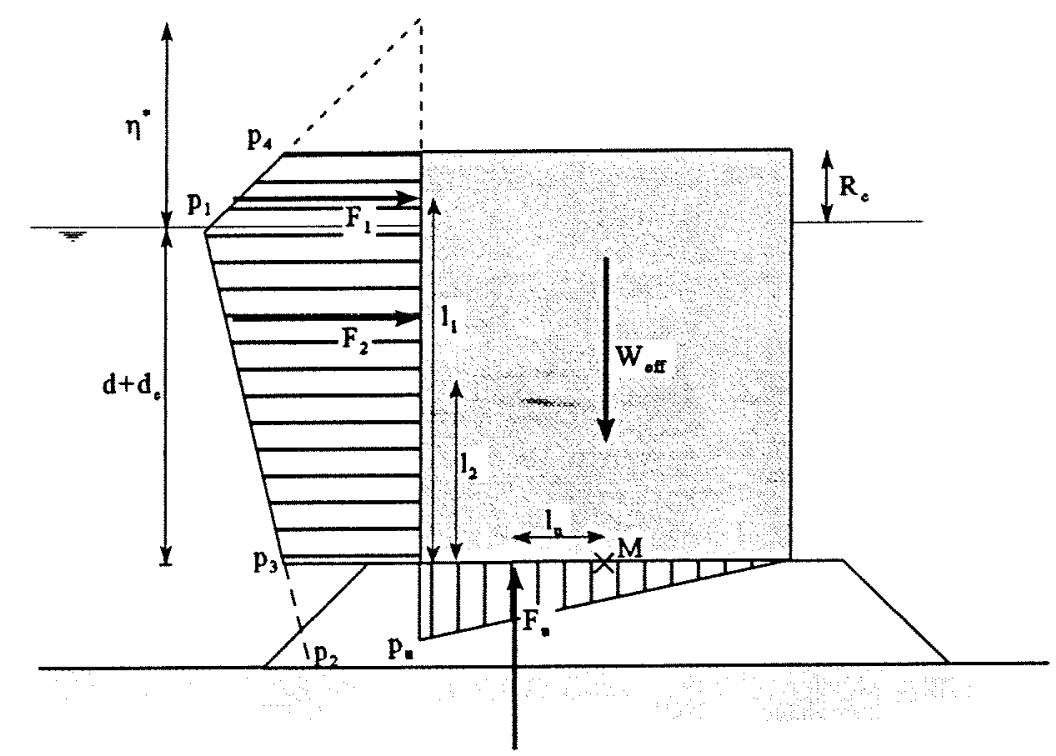

Figure 4.6: Wave forces according to [Goda, 1985]

According to Goda, the height over which the wave pressure acts on the caisson is given by:

$$
\eta^{*}=0.75(1+\cos \beta) H_{d}
$$

In which $\beta$ is the wave direction with respect to a line perpendicular to the breakwater. 
The wave pressures are given by (see figure 4.6):

$$
\begin{aligned}
& \mathrm{p}_{1}=\frac{1}{2}(1+\cos \beta)\left(\alpha_{1}+\alpha_{2} \cos ^{2} \beta\right) \gamma_{\mathrm{w}} \mathrm{H}_{\mathrm{d}} \\
& \mathrm{p}_{2}=\frac{\mathrm{p}_{1}}{\cosh \left(\frac{2 \pi \mathrm{h}_{\mathrm{s}}}{\mathrm{L}}\right)} \\
& \mathrm{p}_{3}=\alpha_{3} \mathrm{p}_{1} \quad \text { for } \mathrm{R}_{\mathrm{c}}>\eta^{*} \\
& \mathrm{p}_{4}=\left\{\begin{array}{l}
\left(1-\frac{\mathrm{R}_{\mathrm{c}}}{\eta^{*}}\right) p_{1} \text { for } 0 \leq \mathrm{R}_{\mathrm{c}} \leq \eta^{*} \\
0 \quad
\end{array}\right. \\
& \mathrm{p}_{\mathrm{u}}=\frac{1}{2}(1+\cos \beta) \alpha_{1} \alpha_{3} \gamma_{\mathrm{w}} \mathrm{H}_{\mathrm{d}}
\end{aligned}
$$

Observing the expression for $p_{1}$ shows that Goda implicitly assumes full reflection for head on waves. This coincides with the assumption made in this study in section 4.2.

Dynamic effects are accounted for to a certain extend by means of empirical multiplication factors. Goda observed that the pressure on still water level tends to increase with increasing wave period. To include this effect an empirical factor $\alpha_{1}$ is introduced. Furthermore the pressure on the still water level increases if the height of the rubble foundation increases with regard to the water depth in front of the structure. This effect is probably caused by a change in behaviour of the waves. A smaller depth in front of the caisson tends to induce more breaking waves. This effect is included by the factor $\alpha_{2}$. The pressure on top of the rubble foundation $p_{3}$ is found by linear interpolation between $p_{1}$ and $p_{2}$. This is expressed by the factor $\alpha_{3}$. The uplift pressure $p_{u}$ is slightly reduced with respect to the pressure on the front side $p_{3}$. The multiplication factors are given by:

$$
\begin{aligned}
& \alpha_{1}=0.6+\frac{1}{2}\left(\frac{\frac{4 \pi h_{s}}{L}}{\sinh \left(\frac{4 \pi h_{s}}{L}\right)}\right)^{2} \\
& \alpha_{2}=\min \left\{\frac{h_{b}-d}{3 h_{b}}\left(\frac{H_{\text {max }}}{d}\right)^{2} ; \frac{2 d}{H_{\text {max }}}\right\} \\
& \alpha_{3}=1-\frac{d+d_{c}}{h_{s}}\left(1-\frac{1}{\cosh \left(\frac{2 \pi h_{s}}{L}\right)}\right)
\end{aligned}
$$


The expressions for the forces are similar to the ones for the hydrostatic approach. The individual forces are given by:

$$
\begin{aligned}
& F_{1}=\frac{1}{2}\left(p_{1}+p_{4}\right) \cdot \min \left\{\begin{array}{c}
R_{c} \\
\eta^{*}
\end{array}\right\} \\
& F_{2}=\frac{p_{1}+p_{3}}{2}\left(d+d_{c}\right) \\
& F_{u}=\frac{1}{2} p_{u} B_{c}
\end{aligned}
$$

The lever arms of the individual forces are given by:

$$
\begin{aligned}
& l_{1}=d+d_{c}+\frac{\left(p_{1}+2 p_{4}\right) \cdot \min \left\{\begin{array}{c}
R_{c} \\
\eta^{*}
\end{array}\right\}}{3\left(2 p_{1}+p_{4}\right)} \\
& l_{2}=\frac{2 p_{1}+p_{3}}{3\left(p_{1}+p_{3}\right)}\left(d+d_{c}\right) \\
& l_{u}=\frac{B}{6}
\end{aligned}
$$

The tilting moment due to the horizontal forces is given by:

$$
\mathrm{M}_{\mathrm{H}}=\mathrm{l}_{1} \mathrm{~F}_{1}+\mathrm{l}_{2} \mathrm{~F}_{2}
$$

And the moment of the vertical forces by:

$$
\mathrm{M}_{\mathrm{V}}=\mathrm{l}_{\mathrm{u}} \mathrm{F}_{\mathrm{u}}=\frac{1}{12} \mathrm{p}_{3} \mathrm{~B}_{\mathrm{c}}^{2}
$$




\subsubsection{Comparison of the three wave load models}

The horizontal force as a function of the design wave height is plotted in figure 4.7.

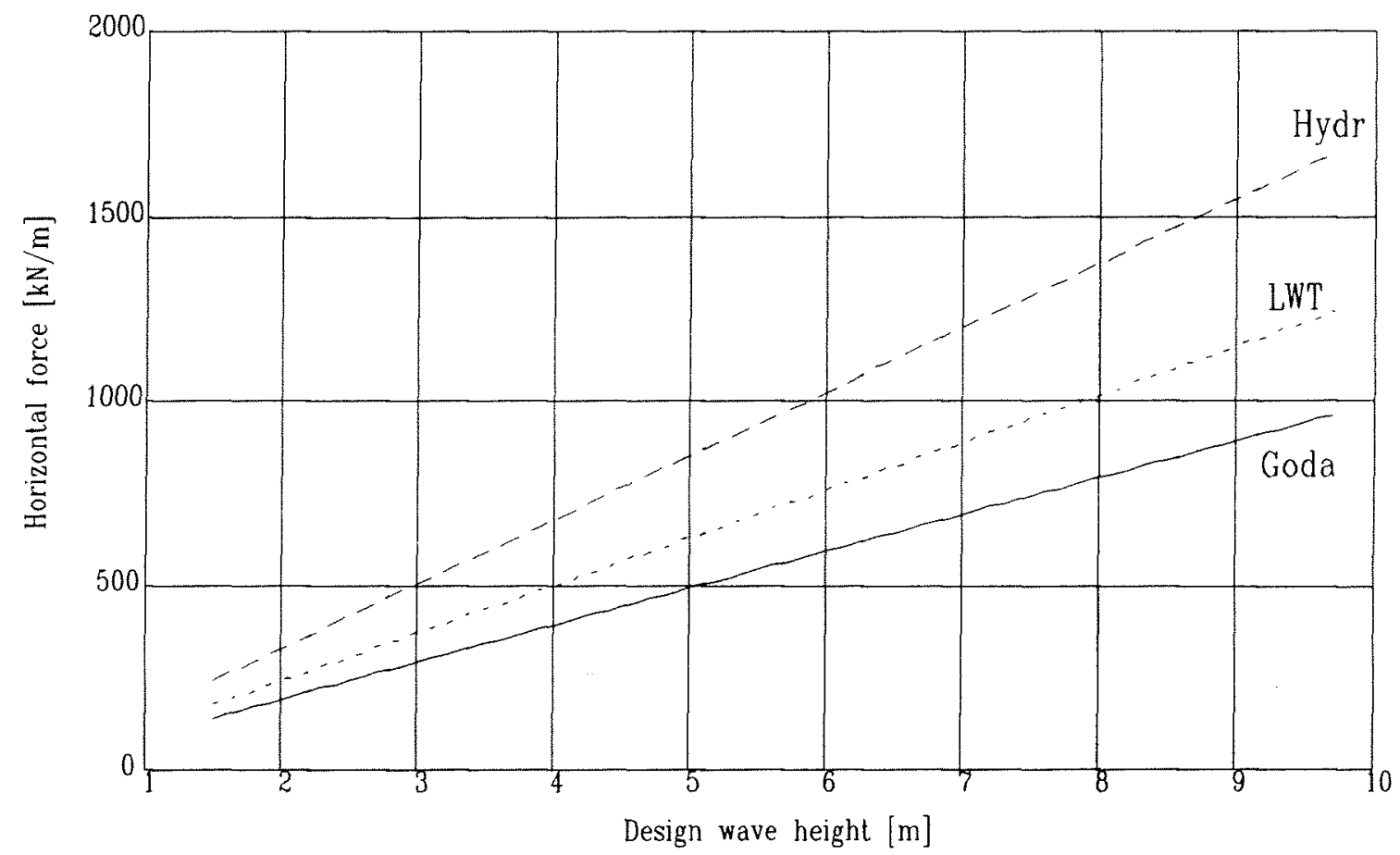

Figure 4.7: Horizontal force on the caisson calculated with three different wave load models (Base case, $\mathrm{T}=8 \mathrm{~s}$ )

Goda's method takes into account dynamic effects which are strongly influenced by the height of the rubble foundation. In the base case the height of the foundation is set to zero. In that case Goda's method predicts lower forces then Linear Wave Theory. The forces calculated by means of the hydrostatic approach are an upper bound of the forces calculated by Linear Wave Theory. For an infinite wave period these two methods result in equal forces. 
Figure 4.8 shows the wave forces calculated for a rubble mound with a height of $10 \mathrm{~m}(\mathrm{~d}=5 \mathrm{~m}$, $h_{s}=15 \mathrm{~m}$ ). Now the dynamic effects gain importance. Since only Goda's method includes these dynamic effects, this method results in higher forces.

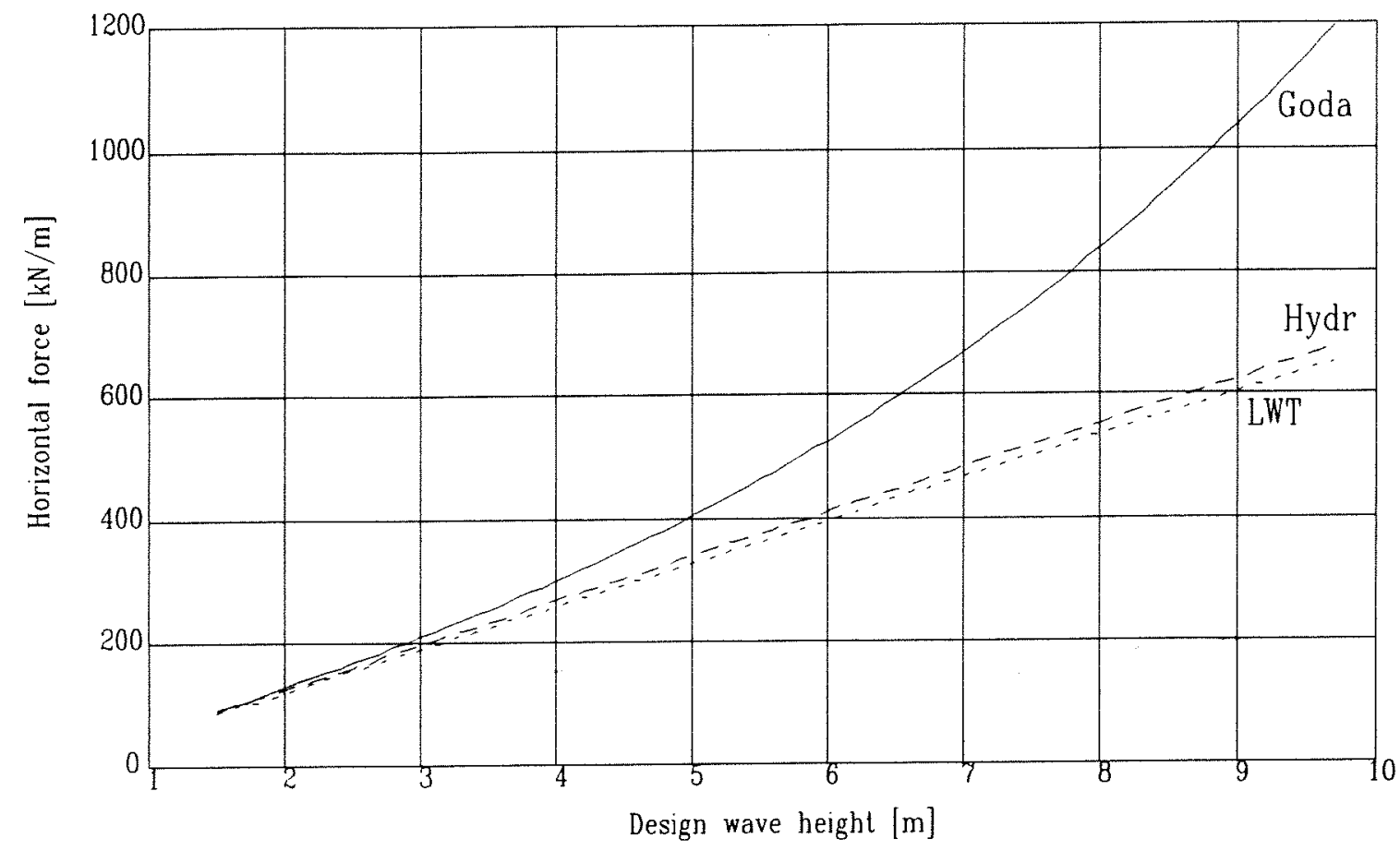

Figure 4.8: Horizontal force on the caisson calculated with three different wave load models (Mound height raised $10 \mathrm{~m}$ with respect to the base case, $\mathrm{T}=8 \mathrm{~s}$ )

\subsection{Width of the caisson as a function of caisson height and wave height}

When the wave forces and the strength of the caisson as a function of width and height are known, the required caisson width can be calculated if the wave height and the caisson height are known. This will be carried out for two mechanisms:

- $\quad$ Sliding of the caisson over the rubble foundation;

- Rotation failure of the caisson. 
For sliding the load is the horizontal wave force; the strength the maximum friction force between the rubble and the base plate of the caisson. The equilibrium is fulfilled if:

$$
\mathrm{F}_{1}+\mathrm{F}_{2} \leq \mathrm{f}\left(\mathrm{W}_{\mathrm{eff}}-\mathrm{F}_{\mathrm{u}}\right)
$$

In which:

$\mathrm{F}_{1}+\mathrm{F}_{2}$ : Total horizontal wave load on the caisson $[\mathrm{kN} / \mathrm{m}]$;

$\mathrm{F}_{\mathrm{u}}$ : Uplift force $[\mathrm{kN} / \mathrm{m}]$;

$W_{\text {eff: }}$ Effective weight of the caisson $[\mathrm{kN} / \mathrm{m}]$,

defined as: $\mathrm{W}_{\text {eff }}=\mathrm{B}_{\mathrm{c}}\left(\mathrm{h}_{\mathrm{c}}\left(\gamma_{\mathrm{c}}-\gamma_{\mathrm{w}}\right)+\mathrm{R}_{\mathrm{c}} \gamma_{\mathrm{w}}\right)$;

f: $\quad$ friction coefficient between the rubble foundation and the base plate of the caisson $[-]$

Substituting in the right hand side of the equation the expressions for the effective weight $\left(\mathrm{W}_{\text {eff }}\right)$ and the uplift force $\left(F_{u}\right)$ results in the following expression for the caisson width required to prevent sliding:

$$
B_{\text {cslid }}=\frac{F_{1}+F_{2}}{f\left(h_{c}\left(\gamma_{c}-\gamma_{w}\right)+\max \left\{\begin{array}{c}
R_{c} \\
0
\end{array}\right\}\right)-\frac{p_{u}}{2}}
$$

Rotation failure is concerned with the moment equilibrium of the caisson. There are several ways in which this kind of failure can occur [Burcharth et al., 1995]. However, in this case a simple formulation is chosen, based on acceptable pressures under the caisson.

The stresses are the result of a superposition of the stresses due to the vertical force and the stresses due to the tilting moment. In principle tensile stresses in soil are not possible. Therefore, two different types of effective soil stress distributions are possible under the caisson floor; a trapezoidal distribution and a triangular distribution (figure 4.9). 

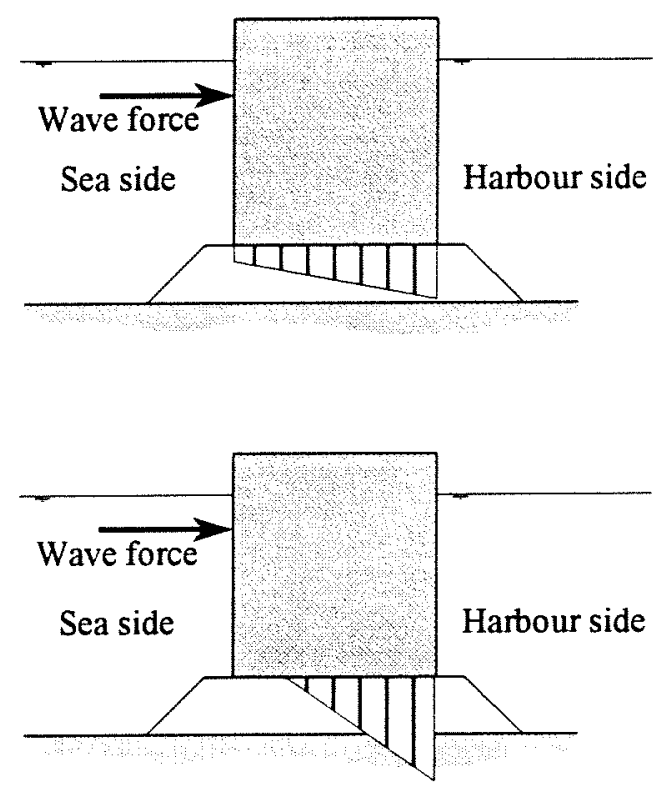

Figure 4.9: Possible distributions of effective soil stress under a caisson

If the effective soil stress on the sea side is limited to positive values, only the trapezoidal type is valid (see annex II). The requirement of positive stresses on the sea side is written as:

$$
\sigma_{\text {sea }} \geq 0
$$

The stress on the harbour side should be limited to a maximum. This can be expressed as:

$$
\sigma_{\text {harb }} \leq \sigma_{\max }
$$

For a trapezoidal pressure distribution the following formula gives the stresses under the corners of the caisson floor:

$$
\sigma=\frac{\sum \mathrm{V}}{\mathrm{B}_{\mathrm{c}}} \pm \frac{\sum \mathrm{M}}{\frac{1}{6} \mathrm{~B}_{\mathrm{c}}^{2}}
$$

In which:

$\Sigma \mathrm{V}: \quad$ sum of vertical loads on the structure;

$\Sigma \mathrm{M}$ : sum of tilting moments due to the wave load with respect to the middle of the base plate.

Substituting the expressions of section 4.4 results in the following formula for the stresses under the caisson:

$$
\sigma=\frac{W_{e f f}-F_{u}}{B_{c}} \pm \frac{M_{H}+\frac{1}{12} p_{u} B_{c}^{2}}{\frac{1}{6} B_{c}^{2}}
$$


The requirement of minimum pressure at the sea side can now be written as:

$$
-\frac{6 \mathrm{M}_{\mathrm{H}}}{\mathrm{B}_{\mathrm{c}}^{2}}+\mathrm{h}_{\mathrm{c}}\left(\gamma_{\mathrm{c}}-\gamma_{\mathrm{w}}\right)+\max \left\{\begin{array}{c}
\mathrm{R}_{\mathrm{c}} \gamma_{\mathrm{w}} \\
0
\end{array}\right\}-\mathrm{p}_{\mathrm{u}} \geq 0
$$

Which results in the following expression for the required width:

$$
B_{c \min }=\sqrt{\frac{6 M_{H}}{h_{c}\left(\gamma_{c}-\gamma_{w}\right)+\max \left\{\begin{array}{c}
R_{c} \gamma_{w} \\
0
\end{array}\right\}-p_{u}}}
$$

The limitation of the maximum pressure on the harbour side can be written as:

$$
\frac{6 M_{H}}{B_{c}^{2}}+h_{c}\left(\gamma_{c}+\gamma_{w}\right)+\max \left\{\begin{array}{c}
R_{c} \gamma_{w} \\
0
\end{array}\right\} \leq \sigma_{\max }
$$

This results in the following expression for the required width:

$$
\mathrm{B}_{\mathrm{cmax}}=\sqrt{\frac{6 \mathrm{M}_{\mathrm{H}}}{\sigma_{\max }-\mathrm{h}_{\mathrm{c}}\left(\gamma_{\mathrm{c}}-\gamma_{\mathrm{w}}\right)-\max \left\{\begin{array}{c}
\mathrm{R}_{\mathrm{c}} \gamma_{\mathrm{w}} \\
0
\end{array}\right\}}}
$$

Figure 4.10 shows an example of the required width per mechanism as a function of the design wave height. The wave loads are calculated by means of the hydrostatic approach. The caisson height is arbitrarily chosen at $h_{c}=17 \mathrm{~m}\left(R_{c}=2 \mathrm{~m}\right)$. In practice this height will have to be chosen based on the functional requirements of the breakwater (chapter 2 ). This will be introduced in section 5.4 . 


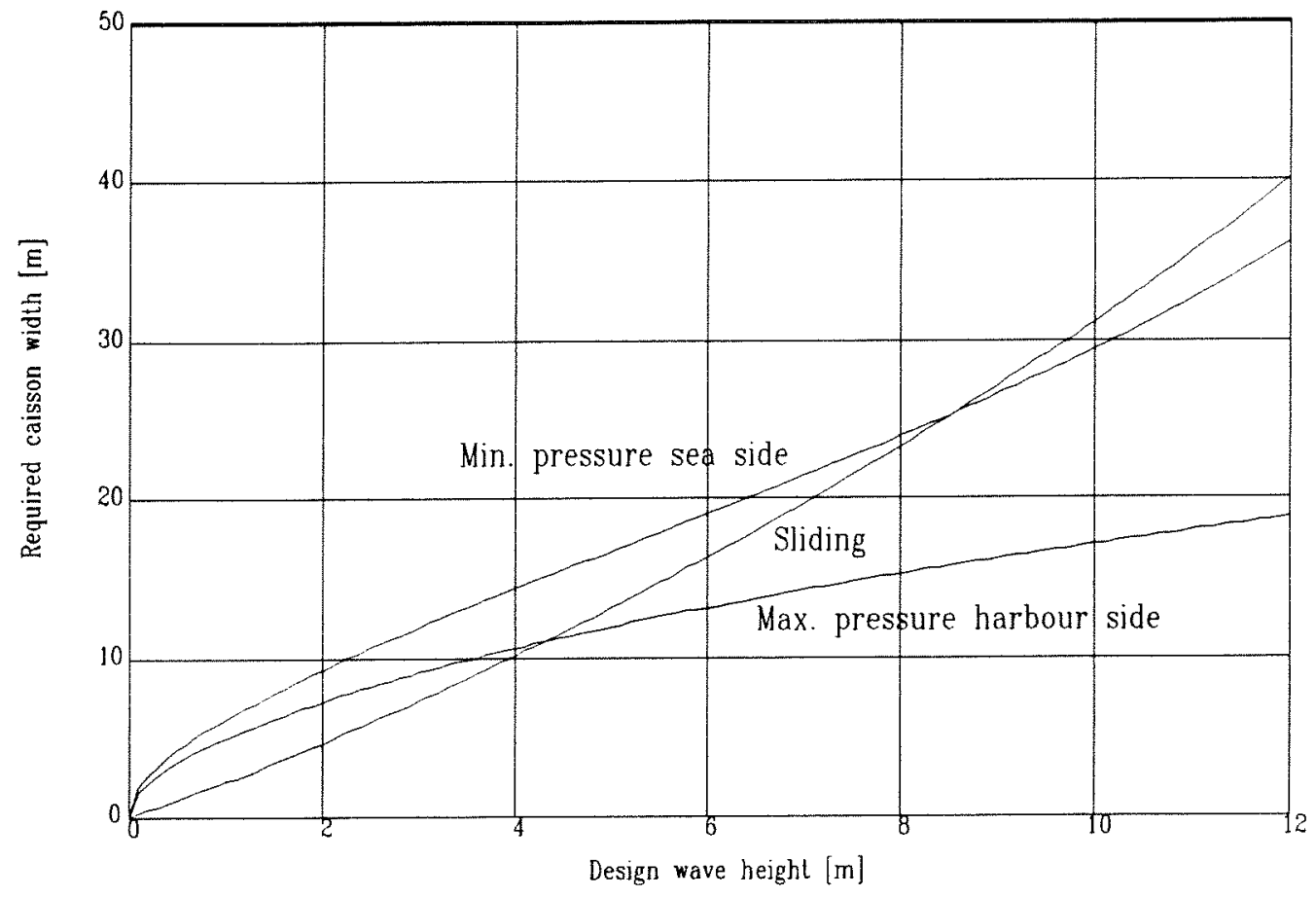

Figure 4.10: Example of required caisson width per mechanism as a function of the design wave height with hydrostatic approach of the wave forces $\left(h_{c}=17 \mathrm{~m}\right)$

From this figure can be concluded that only for very large design wave heights with respect to the crest height of the caisson, sliding determines the required caisson width. Otherwise the caisson width is determined by the limitation of the minimum pressure on the sea side. It seems that the maximum pressure on the harbour side is never decisive. This however depends on the height of the caisson and the value of the maximum effective soil stress. For higher caissons the restriction of the pressure on the harbour side can be decisive (see figure 4.11).

Figure 4.11 shows the required width per mechanism as a function of the crest height for a design wave height $H_{d}=10 \mathrm{~m}$. The wave forces are calculated by means of the hydrostatic approach. 


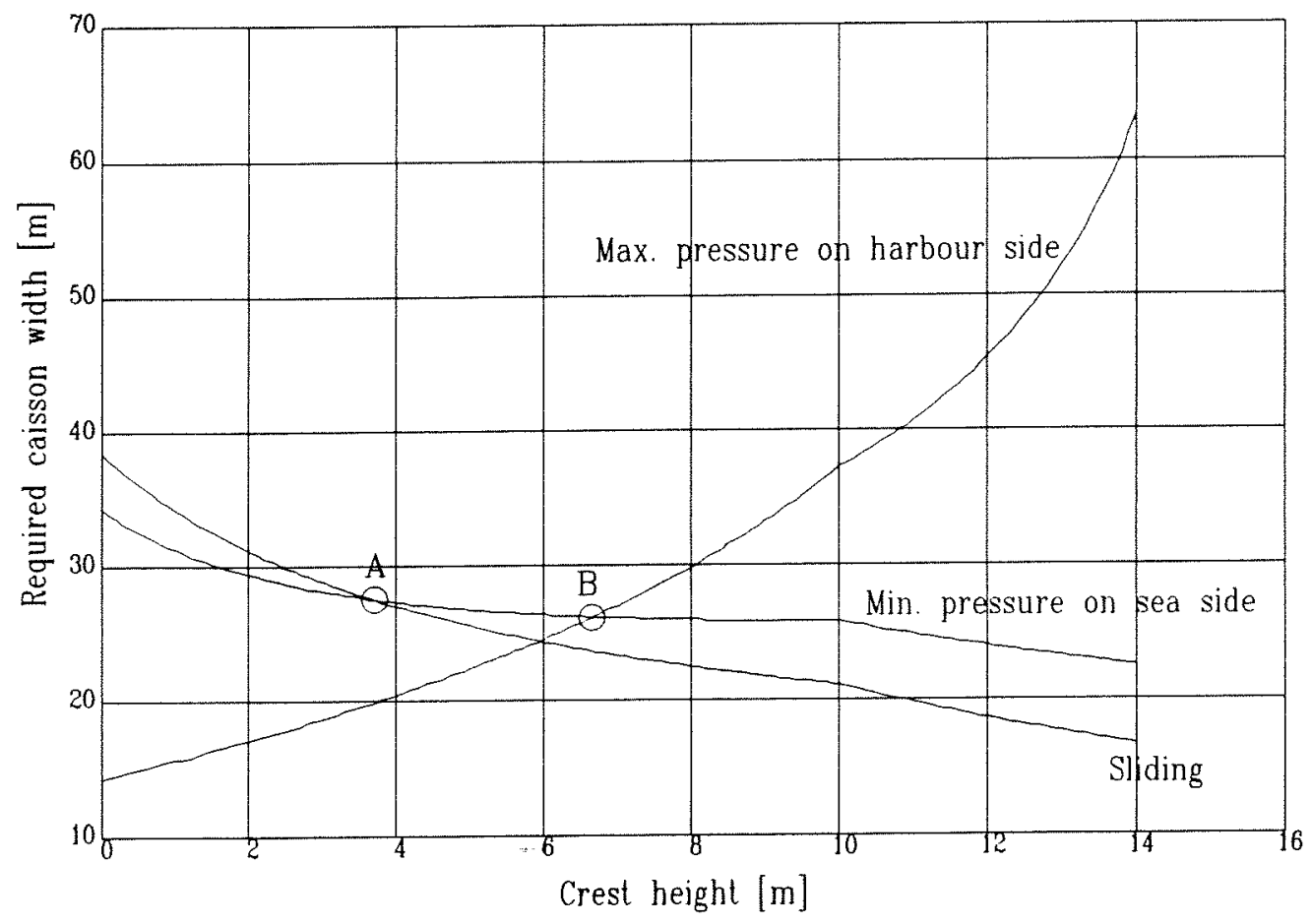

Figure 4.11: Required caisson width as a function of the crest height with hydrostatic approach for the wave forces $\left(\mathrm{H}_{d}=10 \mathrm{~m}\right)$

Again, for low caissons with respect to the design wave height, the caisson width is determined by sliding (on the left side of point $A$ ). Furthermore it can be seen that for crest heights above 6.5 $\mathrm{m}$ (on the right side of point $B$ ) the pressure on the harbour side determines the caisson width.

\subsection{Optimal caisson dimensions}

\subsubsection{Hydrostatic approach of the wave forces}

Figure 4.12 shows the area of the cross section as a function of the crest height for several design wave heights. The breakwater properties are given in section 4.2. The maximum wave height is determined by the breaking limit of section 4.3 (figure 4.2). The hydrostatic approach is used to determine the wave forces. 


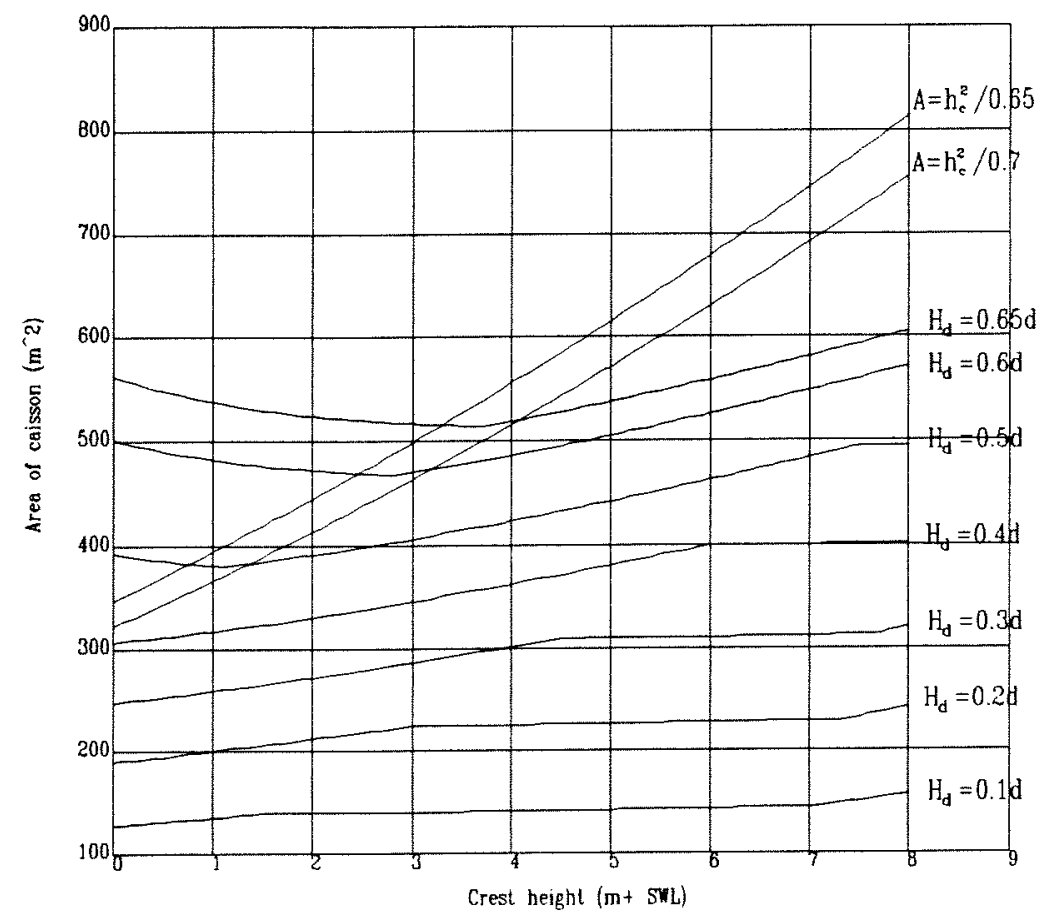

Figure 4.12: Area of the caisson cross section for several wave heights (water depth $15 \mathrm{~m}$, hydrostatic approach)

For lower wave heights no optimum is found with a crest above still water level. For higher waves the optimum is found for the situation where the required width against sliding equals the required width against rotation (minimum pressure). The ratio $\frac{h_{c}}{B_{c}}$ lies between 0.65 and 0.7 . This is a considerable wider caisson then follows from the design rules of PIANC [PIANC, 1976].

\subsubsection{Linear wave theory}

When applying the linear wave theory to determine the wave forces, the pictures change. A very important difference is that the forces are now influenced by the wave period. Figure 4.13 shows the area of the caisson cross section for a wave period of $T=8 \mathrm{~s}$. Figure 4.14 for a wave period of $\mathrm{T}=12 \mathrm{~s}$. 


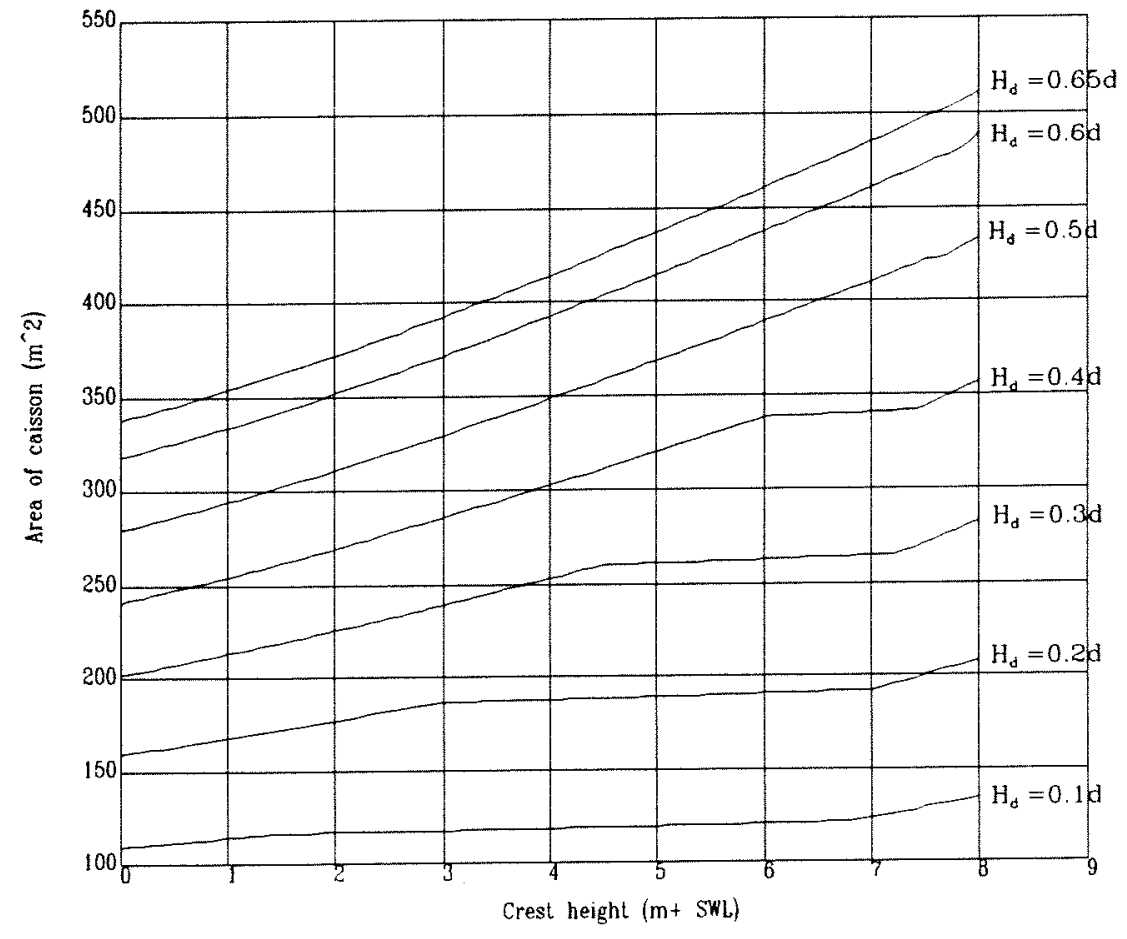

Figure 4.13: Area of the caisson cross section for several wave heights (water depth $15 \mathrm{~m}, \mathrm{~T}=8 \mathrm{~s}$, linear wave theory)

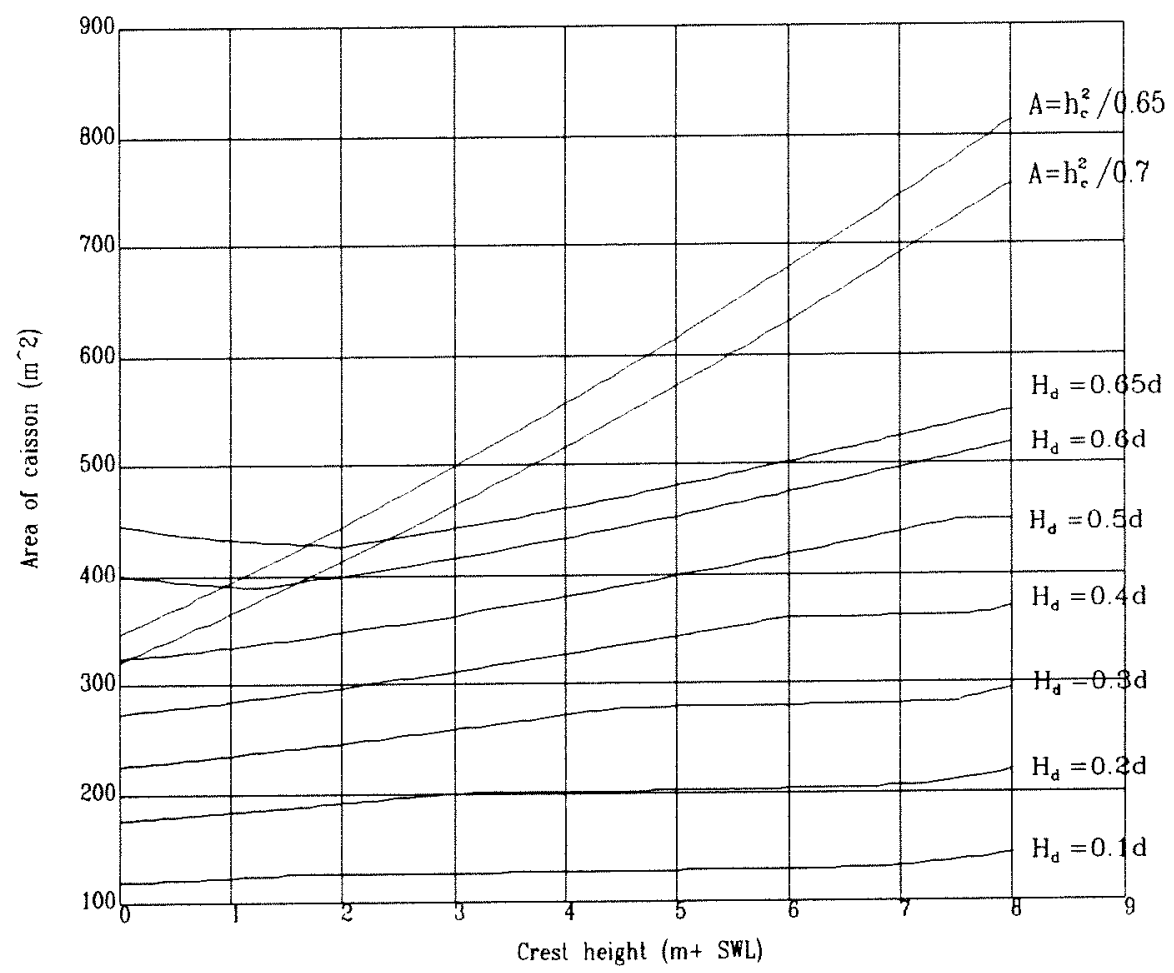

Figure 4.14: Area of the caisson cross section for several wave heights (water depth $15 \mathrm{~m}, \mathrm{~T}=12 \mathrm{~s}$, linear wave theory) 
The wave forces increase with increasing wave period. This explains the higher required caisson dimensions for the longer wave period (figure 4.14). For finite wave periods the wave forces are lower then calculated by means of the hydrostatic approach. Therefore the found caisson dimensions are smaller then those calculated with the hydrostatic approach. For relatively short wave periods no optimum is found with a crest height above still water level $\left(R_{c}>0\right.$, figure 4.1$)$. When applying linear wave theory, the assumed pressure distribution gets a form causing the horizontal forces to decrease and the lever arm of the horizontal forces to increase compared to the hydrostatic approach (figures 4.3 and 4.4). This behaviour results in an increasing importance of the tilting moment compared to the horizontal force. Now rotation failure will be decisive over sliding earlier. In figure 4.13 rotation failure is always decisive over sliding. The caisson width is again relatively high compared to the results of [PIANC, 1976].

\subsubsection{Goda}

The method of Goda also shows the influence of the wave period. Figure 4.15 and figure 4.16 show the required area of the caisson cross section for $\mathrm{T}=8 \mathrm{~s}$ and $\mathrm{T}=12 \mathrm{~s}$ respectively.

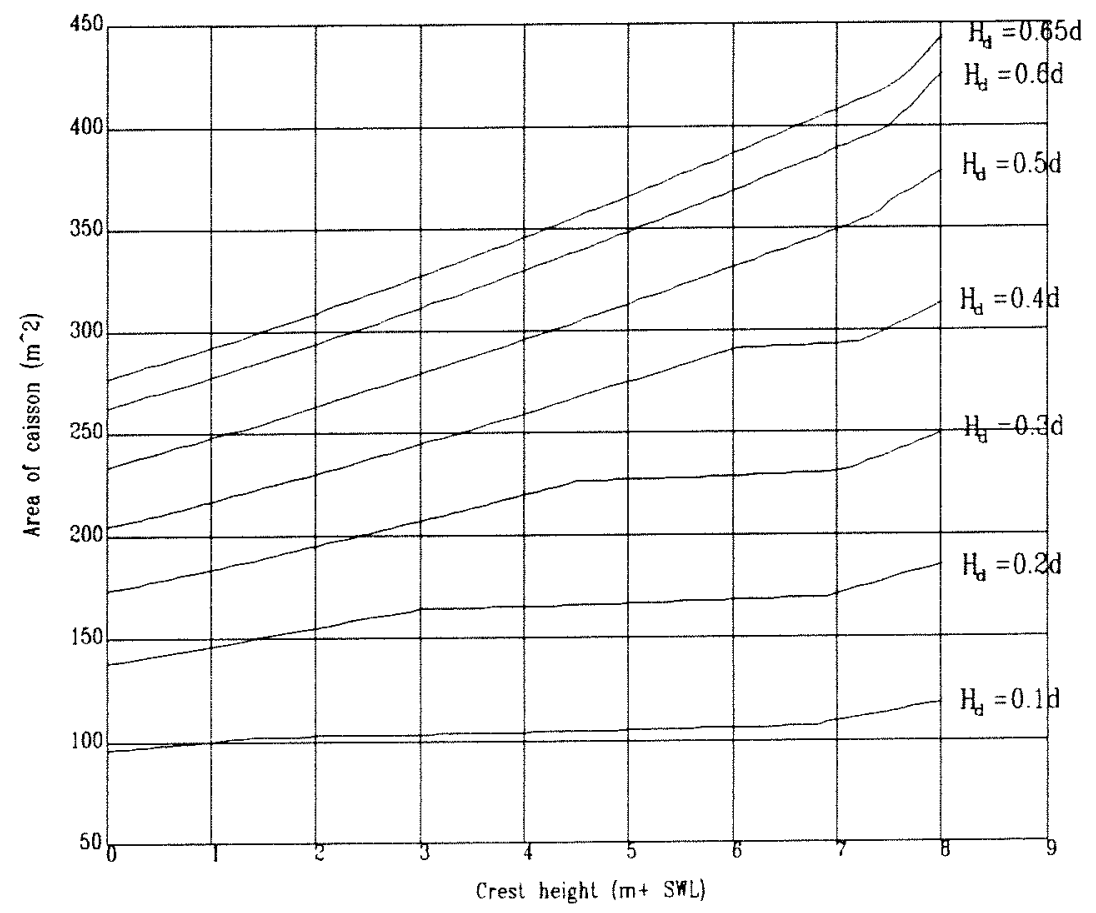

Figure 4.15: Area of the caisson cross section for several wave heights (water depth $15 \mathrm{~m}, \mathrm{~T}=8 \mathrm{~s}$, Goda method for wave forces) 


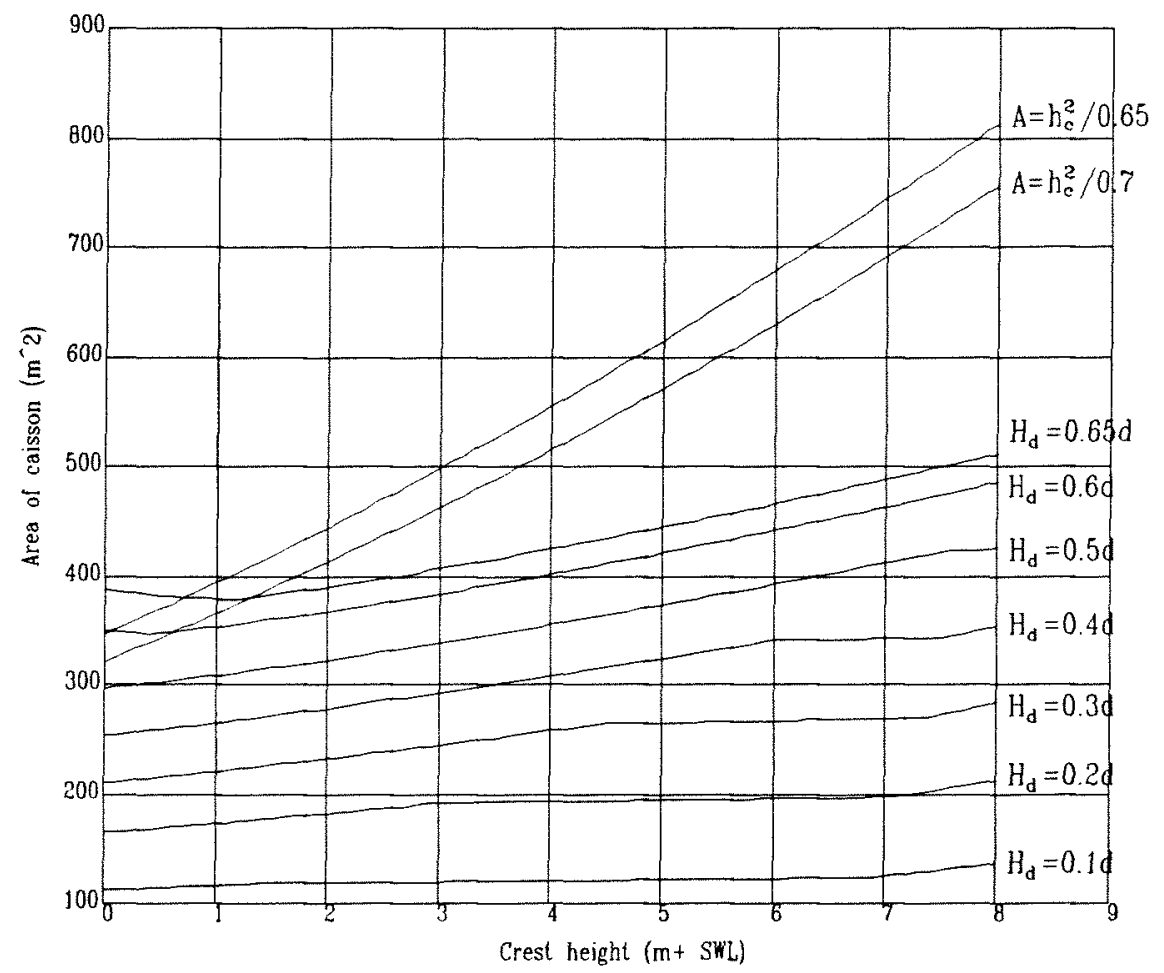

Figure 4.16: Area of the caisson cross section for several wave heights (Water depth $15 \mathrm{~m}, \mathrm{~T}=12 \mathrm{~s}$, Goda method for wave forces)

The results are similar to those found with the linear wave theory. Since Goda's method gives in this case lower forces than those predicted by linear theory (section 4.4.5), the found caisson dimensions are smaller. The caissons are relatively wide compared to [PIANC, 1976].

\subsection{Concluding remarks}

Minimization of the construction costs of a breakwater caisson results in a relatively constant height/width ratio. The found optimal caisson dimensions result in considerable wider caissons then observed in practice or predicted by the design rules of [PIANC, 1976]. Taking into account the capitalized risk influences the caisson dimensions towards more narrow caissons. This is shown in the next chapter. 



\section{$5 \quad$ Minimization of the complete cost function}

\subsection{Introduction}

In the previous chapter only the area of the caisson cross section was minimized, assuming the construction costs proportional to the area of this cross section. In this chapter the complete cost function consisting of construction costs and capitalized risk is minimized in the $h_{c}-B_{c}-s p a c e$ (height and width of the caisson). Two random variables are used in this chapter; the significant wave height and the water level in front of the caisson. The distributions of these random variables are given in section 5.2 .

In section 5.3 and 5.4 the optimization is carried out with the risk due to ULS-failure included in the cost function. The function used in these two sections reads:

$$
\mathrm{C}_{\text {lifetime }}\left(\mathrm{h}_{\mathrm{c}}, \mathrm{B}_{\mathrm{c}}\right)=\mathrm{I}_{\text {constr }}\left(\mathrm{h}_{\mathrm{c}}, \mathrm{B}_{\mathrm{c}}\right)+\sum_{\mathrm{n}=1}^{N} \frac{\mathrm{P}_{\mathrm{f}}\left(\mathrm{h}_{\mathrm{c}}, \mathrm{B}_{\mathrm{c}}\right) \mathrm{C}_{\mathrm{ULS}}\left(\mathrm{h}_{\mathrm{c}}, \mathrm{B}_{\mathrm{c}}\right)}{\left(1+\mathrm{r}^{\prime}-\mathrm{g}\right)^{\mathrm{n}}}
$$

In section 5.3 only the distribution of the significant wave height is used and the water level is set to its modal value. In section 5.4 both the distribution of the significant wave height and the distribution of the water level are used.

In section 5.5 the influence of risk due to SLS-failure is examined. In this section the cost function is extended to:

$$
C_{\text {lifetime }}\left(h_{c}, B_{c}\right)=I_{\text {constr }}\left(h_{c}, B_{c}\right)+\sum_{n=1}^{N} \frac{P_{f}\left(h_{c}, B_{c}\right) C_{U L S}\left(h_{c}, B_{c}\right)+365 P_{f S L S} C_{S L S}\left(h_{c}, B_{c}\right)}{\left(1+r^{\prime}-g\right)^{n}}
$$

Several calculations in this chapter have been made with the numerical model OPT_VBW. This model is described in annex III. An overview of the input and output of all calculations is given in annex IV. The numerical model has been checked against analytical results. Annex $V$ contains graphs which show these tests. Graphs representing the output of the model are given in annex VI through IX. 


\subsection{Extension of the base case}

\subsubsection{Geometry of the breakwater and costs}

The optimization is carried out for the base case of chapter 4 (table 4.1 and figure 4.1 ). The costs are taken from section 3.4. An overview of the geometry and the costs used is given in table 5.1.

\begin{tabular}{|c|c|}
\hline Design variables: & $h_{c}, B_{c}$ \\
\hline Total breakwater length: & $\mathrm{L}_{\mathrm{brwt}}=6000 \mathrm{~m}$ \\
\hline Failure mechanisms: & $\begin{array}{ll}\text { - } & \text { Sliding; } \\
\text { - } & \text { Rotation. }\end{array}$ \\
\hline Wave load model: & $\begin{array}{l}\text { Hydrostatic approach (see section } \\
4.4 .2 \text { ) }\end{array}$ \\
\hline Transmission model: & Goda [Goda, 1969] \\
\hline Acceptable sign. wave height in harbour basin: & $0.50 \mathrm{~m}$ \\
\hline $\mathbf{I}_{\mathbf{0}}$ & $15000[\$ / \mathrm{m}]$ \\
\hline$I_{\text {concr }}$ & $250[\$ / \mathrm{m}]$ \\
\hline $\mathbf{I}_{\text {sand }}$ & $5[\$ / \mathrm{m}]$ \\
\hline $\mathrm{C}_{\text {ULs }}$ & $\$\left(0.2 I_{\text {constr }}\left(h_{c}, B_{c}\right)+564 \cdot 10^{6}\right),-$ \\
\hline $\mathrm{C}_{\mathrm{SLS}}$ & $\$ 750000,-$ \\
\hline Net interest rate: & $r^{\prime}=5 \%$ \\
\hline Growth rate: & $g=3 \%$ \\
\hline Lifetime: & $\mathrm{N}=50$ years \\
\hline Specific density of concrete: & $\gamma_{\text {concr }}=24 \mathrm{kN} / \mathrm{m}^{3}$ \\
\hline Specific density of filling sand: & $\gamma_{\mathrm{sand}}=18 \mathrm{kN} / \mathrm{m}^{3}$ \\
\hline Percentage of concrete: & $p=10 \%($ section 3.2 .1$)$ \\
\hline Thickness of concrete cap: & $\mathrm{d}_{\mathrm{cap}}=3 \mathrm{~m}$ \\
\hline Thickness of concrete floor: & $\mathrm{d}_{\text {floor }}=1 \mathrm{~m}$ \\
\hline All other properties: & See table 4.1 \\
\hline
\end{tabular}

Table 5.1: Geometry and cost data used in the optimization 


\subsubsection{Random variables}

An overview of the random variables used is given in table 5.2.

\begin{tabular}{|c|c|c|c|}
\hline Variable & Description & Distribution & Formula \\
\hline $\mathrm{H}_{s ; \text { daily }}$ & $\begin{array}{l}\text { Daily maximum } \\
\text { significant wave } \\
\text { height }\end{array}$ & Gumbel & $\mathrm{F}_{\mathrm{H}_{\mathrm{s}, \mathrm{daj} y}}(\eta)=\mathrm{e}^{-\mathrm{e}^{-\frac{\eta-0.91}{0.21}}}$ \\
\hline $\mathrm{H}_{\mathrm{s} ; \text { yearty }}$ & $\begin{array}{l}\text { Yearly maximum } \\
\text { significant wave } \\
\text { height }\end{array}$ & Gumbel & $F_{H_{s, y e a r l y}}(\eta)=e^{-e^{-\frac{\eta-2.15}{0.21}}}$ \\
\hline$H_{d}$ & Design wave height & Gumbel & $F_{H_{d}}(\eta)=e^{-e^{-\frac{\eta-4.30}{0.42}}}$ \\
\hline $\mathrm{d}_{\text {daily }}$ & $\begin{array}{l}\text { Daily maximum } \\
\text { water depth in front } \\
\text { of the caisson }\end{array}$ & Normal & $F_{d ; \text { daily }}(\delta)=\int_{-\infty}^{\delta} \frac{1}{\sqrt{2 \pi}} e^{-\frac{(x-12.1)^{2}}{2}} d x$ \\
\hline$d_{\text {yearly }}$ & $\begin{array}{l}\text { Yearly maximum } \\
\text { water depth in front } \\
\text { of the caisson }\end{array}$ & $\begin{array}{l}\text { Extreme value } \\
\text { distribution of } \\
d_{\text {daily }}\end{array}$ & $F_{d ; \text { yearly }}(\delta)=\left[\int_{-\infty}^{\delta} \frac{1}{\sqrt{2 \pi}} e^{-\frac{(x-12.1)^{2}}{2}} d x\right]^{365}$ \\
\hline
\end{tabular}

Table 5.2: Overview of random variables and distribution functions

The distribution of the yearly maximum significant wave height is the extreme value distribution of the daily maximum significant wave height. The significant wave height is a statistical property of a sea state. To calculate the wave force, the individual wave height is needed. In this study it is assumed that the design wave height equals:

$$
\mathrm{H}_{\mathrm{d}}=2 \mathrm{H}_{s ; \text { yearly }}
$$


Substitution of (5.9) in the distribution function of the yearly maximum significant wave height results in the distribution of the design wave height given in table 5.2. The probability density function of the significant wave height and the probability density function of the design wave height are plotted in figure 5.1.

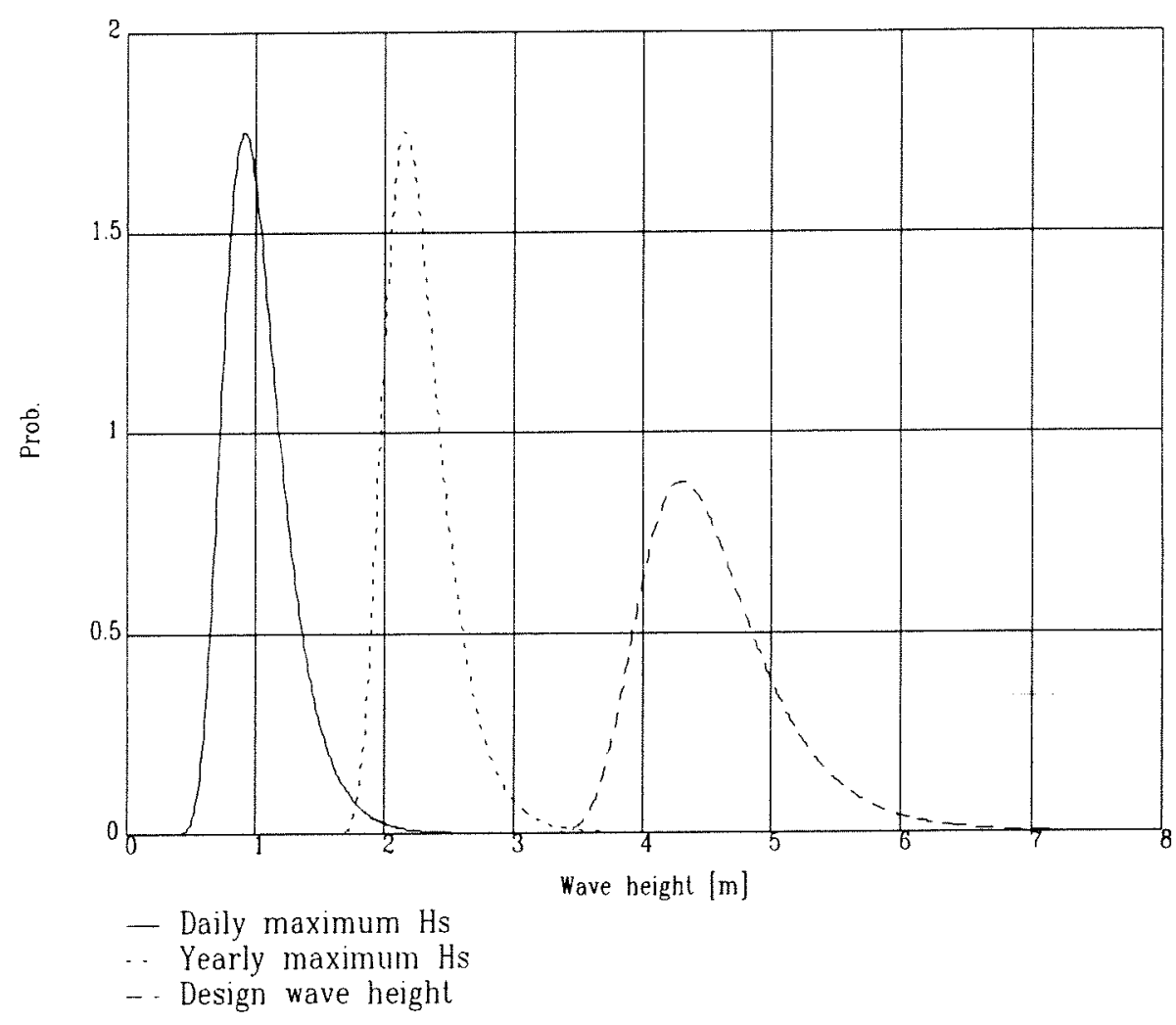

Figure 5.1: Probability densities of significant wave height and design wave height

The daily maximum water depth in front of the caisson is assumed to be Gaussian distributed. The yearly maximum water depth is assumed to be distributed according to the extreme value distribution of the daily maximum water depth. The distributions of the daily and yearly maximum water depth are plotted in figure 5.2. 


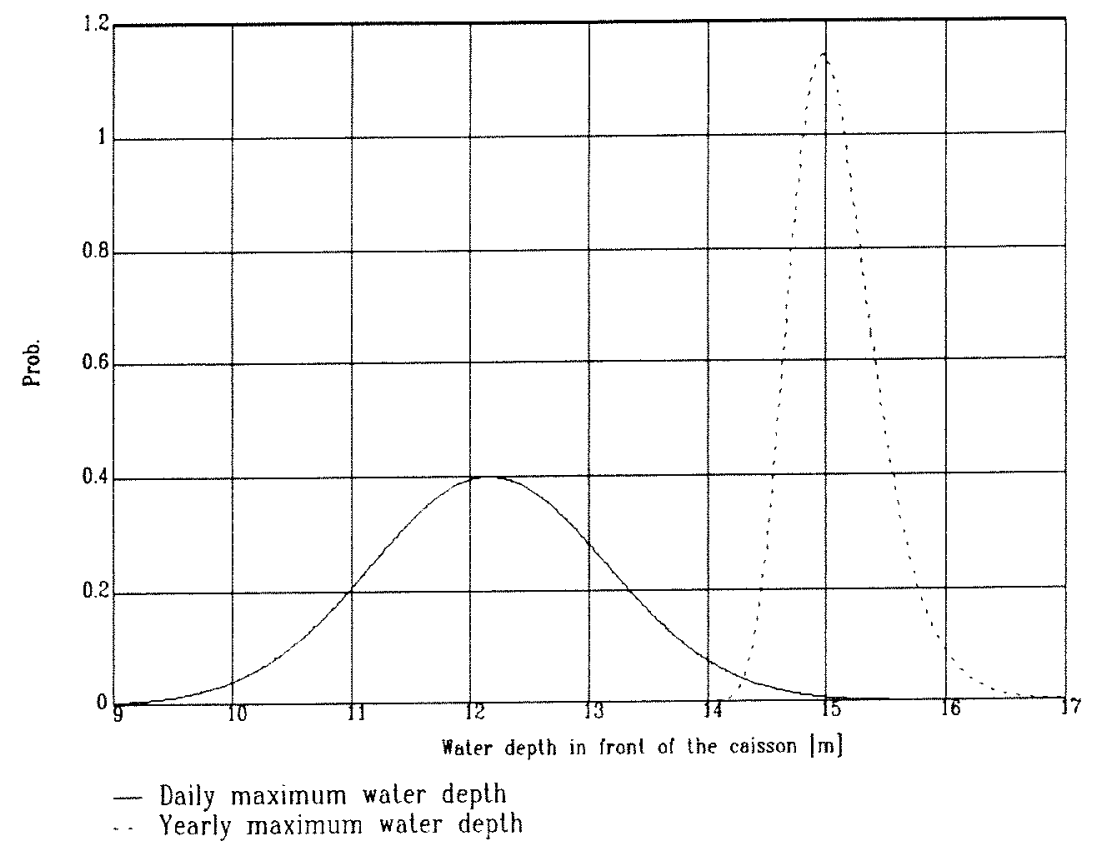

Figure 5.2: Probability densities of the water depth in front of the caisson

\subsection{Reliability functions}

\subsubsection{Introduction}

To calculate the probability of failure, reliability functions have to be defined. A reliability function in general is defined as:

$$
\mathrm{Z}=\mathrm{R}-\mathrm{S}
$$

In which:

$\mathrm{R}$ : $\quad$ strength of the structure (Resistance);

S: load on the structure Solicitation).

Values of $\mathrm{Z}$ below zero indicate failure. Three mechanisms will be considered in this study (chapter 2):

- $\quad$ Sliding of the caisson over the rubble foundation (ultimate limit state, section 5.3.2);

- Rotation failure of the caisson (ultimate limit state, section 5.3.2);

- Excessive wave transmission (serviceability limit state, section 5.3.3). 


\subsubsection{Reliability functions for ultimate limit states}

For the mechanism sliding the strength is given by the maximum friction force (see section 4.5):

$$
F_{R}=f\left(W_{\text {eff }}-F_{u}\right)
$$

And the load by the maximum horizontal wave load:

$$
\mathrm{F}_{\mathrm{S}}=\mathrm{F}_{1}+\mathrm{F}_{2}
$$

Therefore the reliability function for sliding is given by:

$$
Z_{\text {slid }}=f\left(W_{\text {eff }}-F_{u}\right)-F_{1}-F_{2}
$$

The reliability function for rotation failure is related to acceptable pressures under the caisson. In order to define the boundary condition for this failure mechanism, limiting stresses on the sea side and harbour side of the caisson are given. Though exceedance of either one of these stresses is part of one failure mode, separate reliability functions for both are defined in order to discriminate in the causes of rotation failure.

The first requirement for non-failure is:

$$
\sigma_{\text {sea }} \geq 0
$$

The second requirement for non-failure (limitation of the stress on the harbour side) is:

$$
\sigma_{\text {harb }} \leq \sigma_{\max }
$$

For a trapezoidal pressure distribution the pressures under the sides of the caisson are given by (section 4.5):

$$
\sigma=\frac{\Sigma \mathrm{V}}{\mathrm{B}_{\mathrm{c}}} \pm \frac{\Sigma \mathrm{M}}{\frac{1}{6} \mathrm{~B}_{\mathrm{c}}^{2}}
$$

Using this formula, the reliability function for the failure mode "too low pressure on sea side" is given by:

$$
Z_{\text {min }}=\sigma_{\text {sea }}=\frac{W_{\text {eff }}-F_{u}}{B_{c}}-\frac{M_{H}+M_{V}}{\frac{1}{6} B_{c}^{2}}
$$


In general the reliability function for the failure mode "exceedance of maximum effective stress on harbour side" can be written as:

$$
Z_{\max }=\sigma_{\max }-\sigma_{\text {harb }}
$$

In order to calculate the effective stress on the harbour side, two distributions of the effective stress have to be evaluated (see section 4.5 ). Therefore the reliability function is given as:

$$
Z_{\max }=\left\{\begin{array}{cc}
\text { for }\left(W_{\text {eff }}-F_{u}\right)<0 & \text { for }\left(W_{\text {eff }}-F_{u}\right) \geq 0 \text { and } \sigma_{\text {sea }} \geq 0 \\
\sigma_{\max }-\left(\frac{W_{e f f}-F_{u}}{B_{c}}+\frac{M_{H}+M_{V}}{\frac{1}{6} B_{c}^{2}}\right) & \text { for }\left(W_{\text {eff }}-F_{u}\right) \geq 0 \text { and } \sigma_{\text {sea }}<0 \\
\sigma_{\max }-\left(\frac{-2\left(W_{\text {eff }}-F_{u}\right)^{2}}{3\left(M_{H}+M_{V}\right)+\frac{1}{2}\left(3 B_{c}\left(F_{u}-W_{\text {eff }}\right)\right)}\right. &
\end{array}\right.
$$

It should be noted that when the effective weight is lower then the uplift force $\left(\mathrm{W}_{\mathrm{eff}}-\mathrm{F}_{\mathrm{u}}<0\right)$, the caisson will certainly fail. The friction force will be negligible and the requirement of minimum stress on the sea side is not fulfilled.

The complete reliability function for stability of the caisson can now be written as:

$$
Z_{\mathrm{ULS}}=\min \left\{\begin{array}{l}
Z_{\text {slid }} \\
Z_{\min } \\
Z_{\max }
\end{array}\right\}
$$


5.3.3 Reliability function for serviceability limit state (wave transmission)

In general the significant wave height in the harbour basin is related to the significant wave height outside by means of a transmission coefficient which is defined as:

$$
\mathrm{K}_{\mathrm{t}}=\frac{\mathrm{H}_{\mathrm{s} ; \text { basin }}}{\mathrm{H}_{\mathrm{s} ; \text { out }}}
$$

For vertical breakwaters the study by Goda [Goda, 1969] provides an expression for $\mathrm{K}_{\mathrm{t}}$. This expression is written as:

$$
\begin{array}{ll}
\mathrm{K}_{\mathrm{t}}=1 & \text { for } \frac{\mathrm{R}_{\mathrm{c}}}{\mathrm{H}_{\mathrm{s}}}<-2.6 \\
\mathrm{~K}_{\mathrm{t}}=\frac{1}{2}\left[1-\sin \left[\frac{\pi}{2 \alpha}\left(\frac{\mathrm{R}_{\mathrm{c}}}{\mathrm{H}_{\mathrm{s}}}+\beta\right)\right]\right] & \text { for }-2.6 \leq \frac{\mathrm{R}_{\mathrm{c}}}{\mathrm{H}_{\mathrm{s}}} \leq 1.8 \\
\mathrm{~K}_{\mathrm{t}}=0 & \text { for } \frac{\mathrm{R}_{\mathrm{c}}}{\mathrm{H}_{\mathrm{s}}}>1.8
\end{array}
$$

In which:

$\mathrm{R}_{\mathrm{c}}$ : $\quad$ Crest height of the breakwater with respect to the still water level [m];

$\mathrm{H}_{s}$ : Significant wave height outside the harbour basin [m];

$\alpha$ : Empirical factor, taken at 2.2;

$\beta$ : $\quad$ Empirical factor, taken at 0.4 . 
Figure 5.3 shows the significant wave height in the harbour basin as a function of the significant wave height in front of the breakwater.

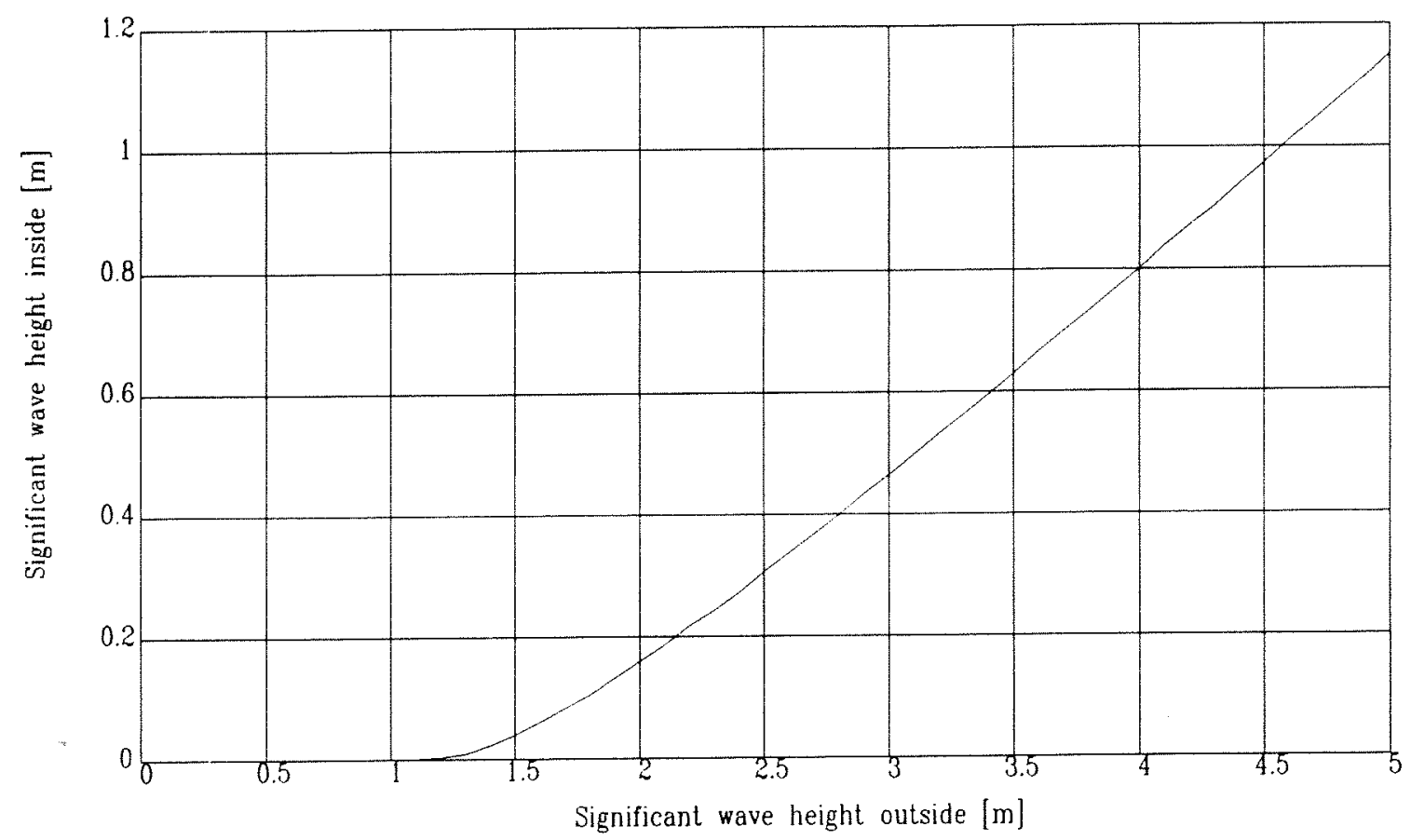

Figure 5.3: Significant wave height in the harbour as a function of the wave height outside (crest height of the breakwater: $2 \mathrm{~m}$ )

Failure occurs if the transmitted significant wave height exceeds the acceptable significant wave height in the harbour basin. Therefore, the reliability function is written as:

$$
\mathrm{Z}_{\text {transm }}=\mathrm{H}_{\mathrm{s} ; \mathrm{acc}}-\mathrm{K}_{\mathrm{t}} \mathrm{H}_{\mathrm{s} ; \text { out }}
$$

In the calculations made with the numerical model the acceptable wave height is set to $0.50 \mathrm{~m}$. 


\subsection{Optimization with one random variable for ultimate limit states}

\subsubsection{Introduction}

In this section the optimization of the caisson design is carried out using only the distribution of the design wave height. The water level is set to its yearly modal value. Only ultimate limit states are considered.

\subsubsection{Analytical solution}

Considering all variables deterministic, the strength of the breakwater can be expressed as the design wave height at which instability of the breakwater caisson occurs. This wave height is called the ultimate wave height. The ultimate wave height can be calculated by finding the root of $(5.20)$ for the design wave height. Figure 5.4 shows a contour plot of the strength of the breakwater.

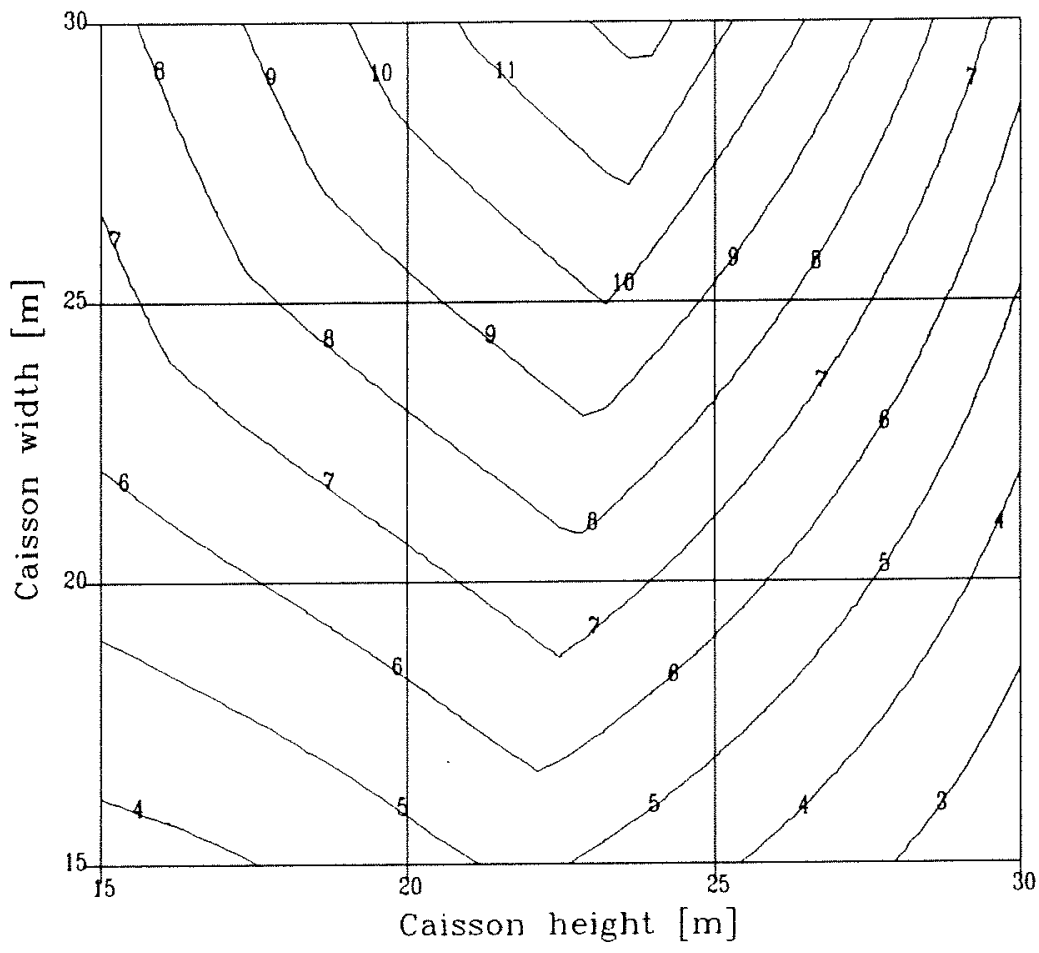

Figure 5.4: Design wave height at which collapse of the caisson occurs (ultimate wave height)

If the wave height is the only random variable, the probability of failure equals the probability that the ultimate wave height is exceeded. This probability can be calculated by substituting the ultimate wave height in the distribution of the design wave height. This procedure results in the contour plot of figure 5.5 . 


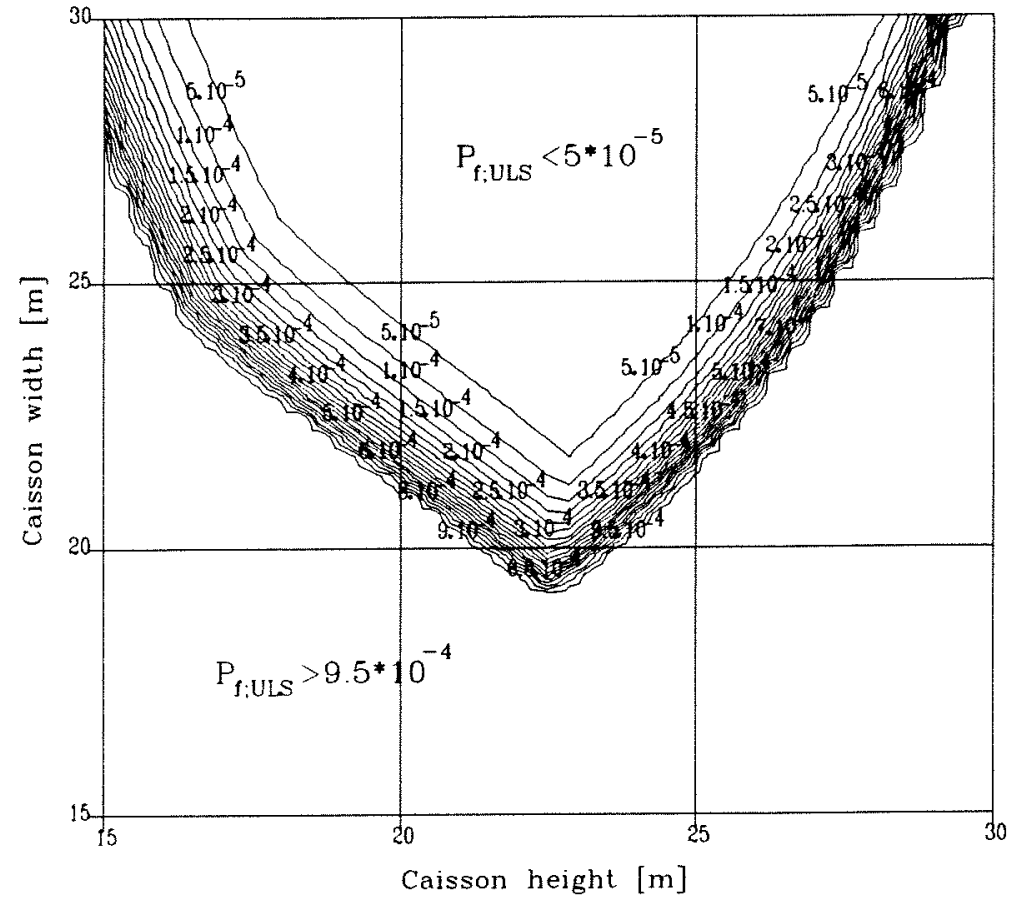

Figure 5.5: Probability of caisson failure as a function of width and height of the caisson

Substituting the probability of failure (figure 5.2) and the cost data (table 5.1) in the cost function (5.1) results in a contour plot of the total lifetime costs as a function of width and height of the caisson (figure 5.6).

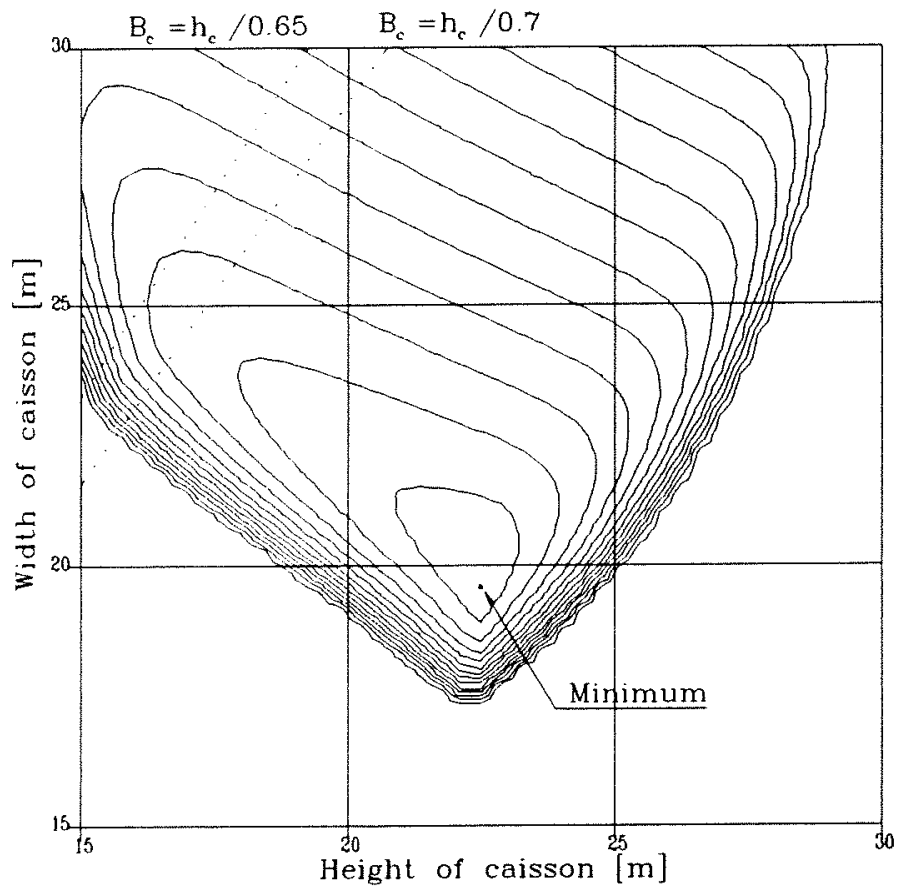

Figure 5.6: Total lifetime costs as a function of height and width of the caisson (base case) 
The optimum is found at a caisson height of approximately $22.5 \mathrm{~m}$ and a width of approximately $20.0 \mathrm{~m}$. This results in an optimal probability of failure of appr. $4.0 \cdot 10^{-4}$ per year. In chapter 4 was found that the optimal height/width ratio was in general between 0.65 and 0.7 . These height/width ratios are indicated by dotted lines in figure 5.3. Comparison to the results of optimization of the complete cost function shows that minimizing the area of the caisson cross section does not necessarily result in an optimal design. It seems that the risk component has a large influence on the optimal caisson dimensions.

\subsubsection{Influence of interest rate and lifetime of the structure}

The influence of the interest rate and the life time of the structure is examined by means of the program OPT_VBW, described in annex III. A short overview of the input and the results of the calculations is given in table 5.3. A more extensive overview is given in annexes IV, VI and VII.

\begin{tabular}{|l|l|l|l|l|l|l|}
\hline \multirow{2}{*}{ Run number } & \multicolumn{2}{|l|}{ Input } & \multicolumn{3}{|l|}{ Results (optimal design) } \\
\cline { 2 - 8 } & $\begin{array}{l}\text { Net } \\
\text { interest }\end{array}$ & $\begin{array}{l}\text { Growth } \\
\text { rate }\end{array}$ & Lifetime & $\begin{array}{l}\text { Caisson } \\
\text { height }\end{array}$ & $\begin{array}{l}\text { Caisson } \\
\text { width }\end{array}$ & $\begin{array}{l}\text { Probability } \\
\text { of failure } \\
\text { (ULS) }\end{array}$ \\
\cline { 2 - 8 } & {$[\%]$} & {$[\%]$} & [years] & {$[\mathrm{m}]$} & {$[\mathrm{m}]$} & {$\left[10^{-1 / y e a r]}\right.$} \\
\hline 1 & 0 & 0 & 50 & 22.62 & 20.16 & 2.98 \\
\hline 2 (base case) & 5 & 3 & 50 & 22.50 & 19.98 & 3.97 \\
\hline 3 & 5 & 0 & 50 & 22.33 & 19.35 & 9.32 \\
\hline 4 & 10 & 0 & 50 & 22.32 & 18.67 & 17.8 \\
\hline 5 & 5 & 3 & 25 & 22.48 & 18.73 & 14.4 \\
\hline 6 & 5 & 3 & 100 & 22.72 & 20.14 & 3.25 \\
\hline
\end{tabular}

Table 5.3: Input and results for four interest rates and three lifetimes

Figure 5.7 shows the optimal height and width of the caisson for four different interest rates. Figure 5.8 shows the failure probabilities per failure mode as well as the upper and lower boundary of the system probability of failure. Similar graphs for three lifetimes are shown in annex VII. 


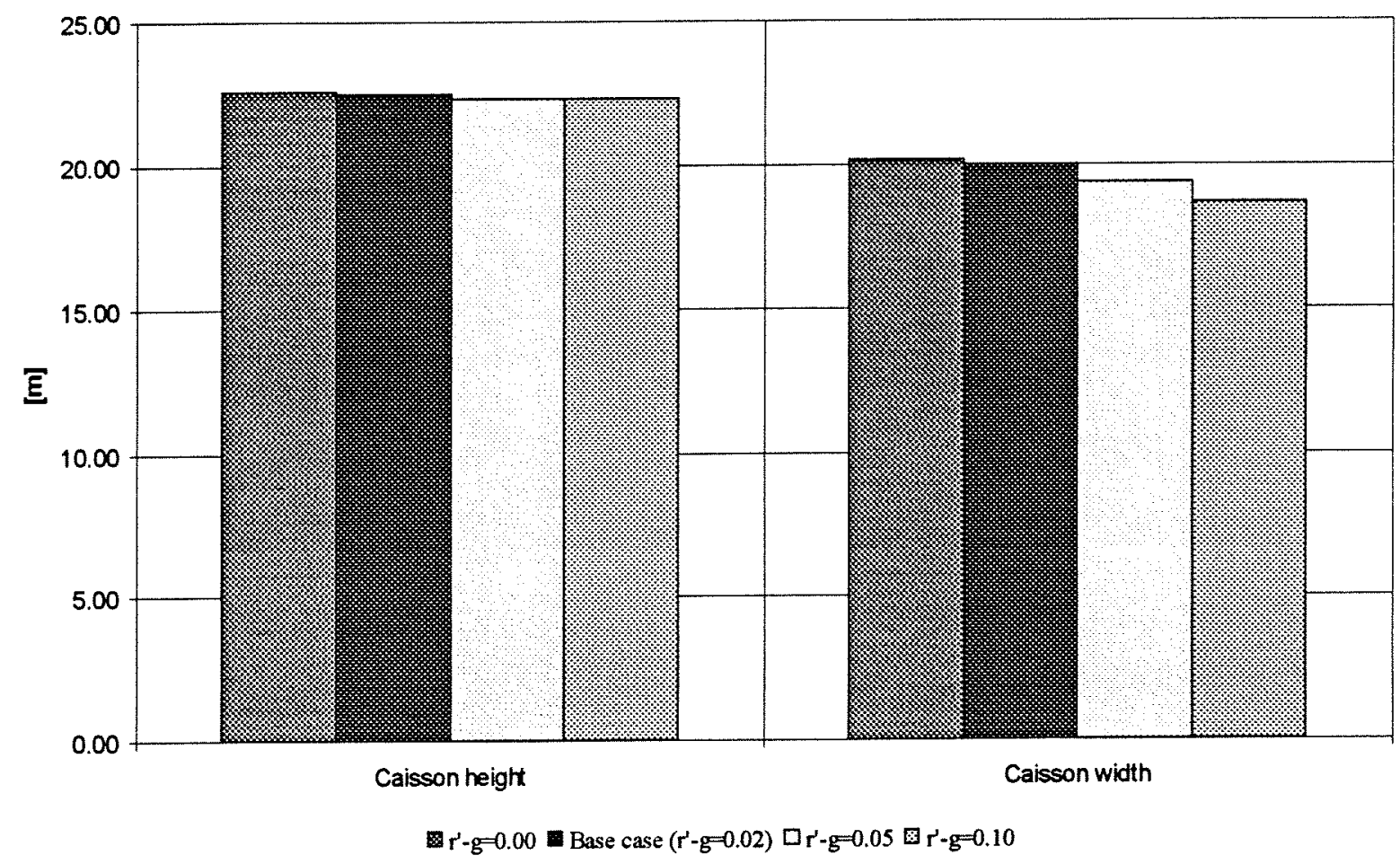

Figure 5.7: Optimal height and width of the caisson (run 1 through 4)

An increase of the rate of interest or a decrease of the lifetime of the structure tends to lower the risk component in the cost function. As is to be expected this lowering of the risk results in a higher acceptable probability of failure of the structure and therefore to smaller caissons. The height/width ratio is in the range 1.10 to 1.20 . These are considerably narrower caissons then found in chapter 4. However, the caisson width is still larger than expected from the design rules of PIANC [PIANC, 1976].

The caisson width is most influenced by a change in the risk. Figure 5.8 shows the costs per metre width as a function of the caisson height and the cost per metre height as a function of the caisson width for a concrete percentage of $10 \%$ (see also section 3.3.1, figure 3.2). 


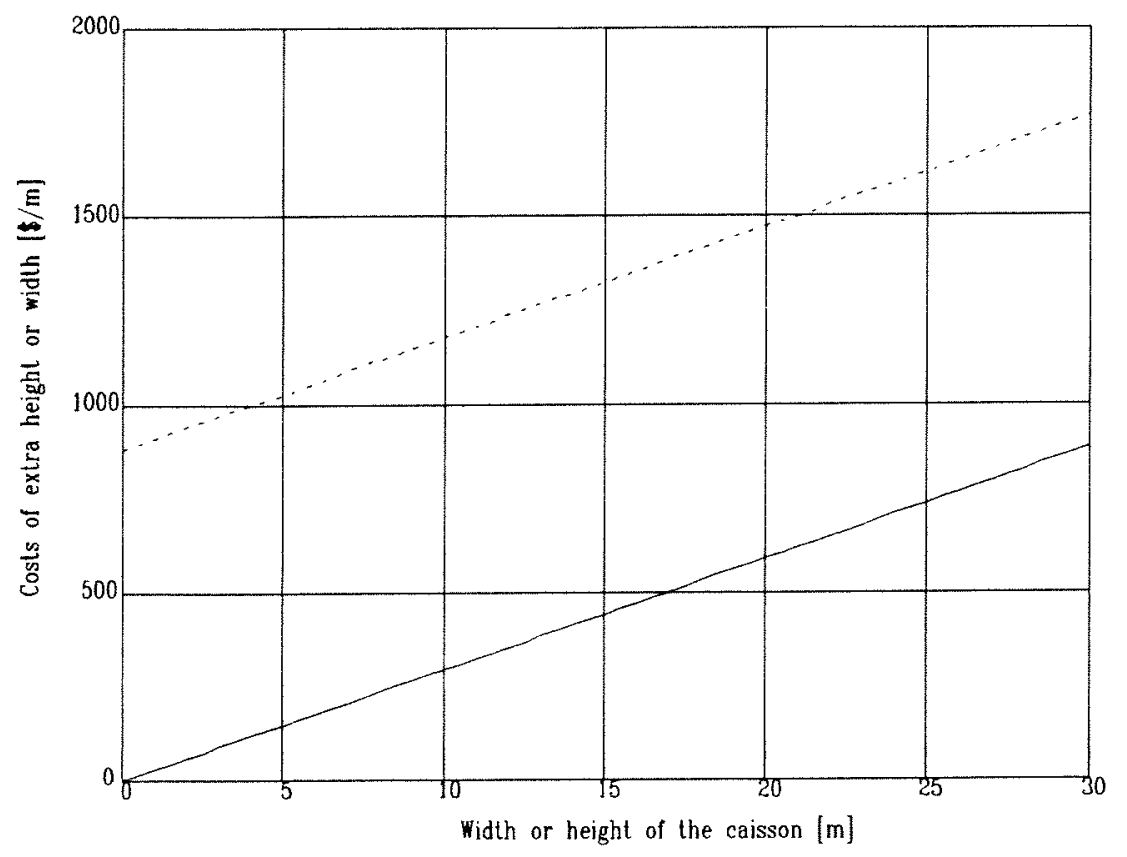

Figure 5.8: Cost per metre width or height of the caisson

The height of the caisson's cap and floor are assumed to be constant in height and to consist fully of concrete. Increasing the width of the caisson increases the area of these parts of the caisson cross section. Increasing the height of the caisson only enlarges the area A (figure 3.2). Since this part of the cross section is considerably cheaper than the cap and floor of the caisson, a metre extra height is cheaper than a metre extra width.

This observation coincides with the fact that the probability of failure of the structure is virtually completely determined by rotation failure only. The reliability function for rotation failure is linear in the caisson height and quadratic in the caisson width. Therefore the probability of rotation failure is mostly influenced by the caisson width, which is the "most expensive" design variable. For sliding of the caisson the caisson height is the most effective design variable, since extra height above the still water level increases the effective weight more than the caisson width does (extra caisson width increases the buoyancy). A too high caisson will cause exceedance of the maximum effective soil stress.

This leads to the following observations:

- Safety against rotation failure demands a certain minimum width and a limited height of the caisson;

- Safety against sliding failure demands a caisson as high as possible and a caisson width as small as possible;

- Due to the fact that rotation failure is mostly influenced by the caisson width, strengthening the caisson against this failure mode will be more expensive than strengthening against sliding failure. 
Apparently an economic design can be found by allowing the largest failure probability for the "most expensive failure mode". This behaviour of the cost function is reflected in the individual failure probabilities of figure 5.9 .

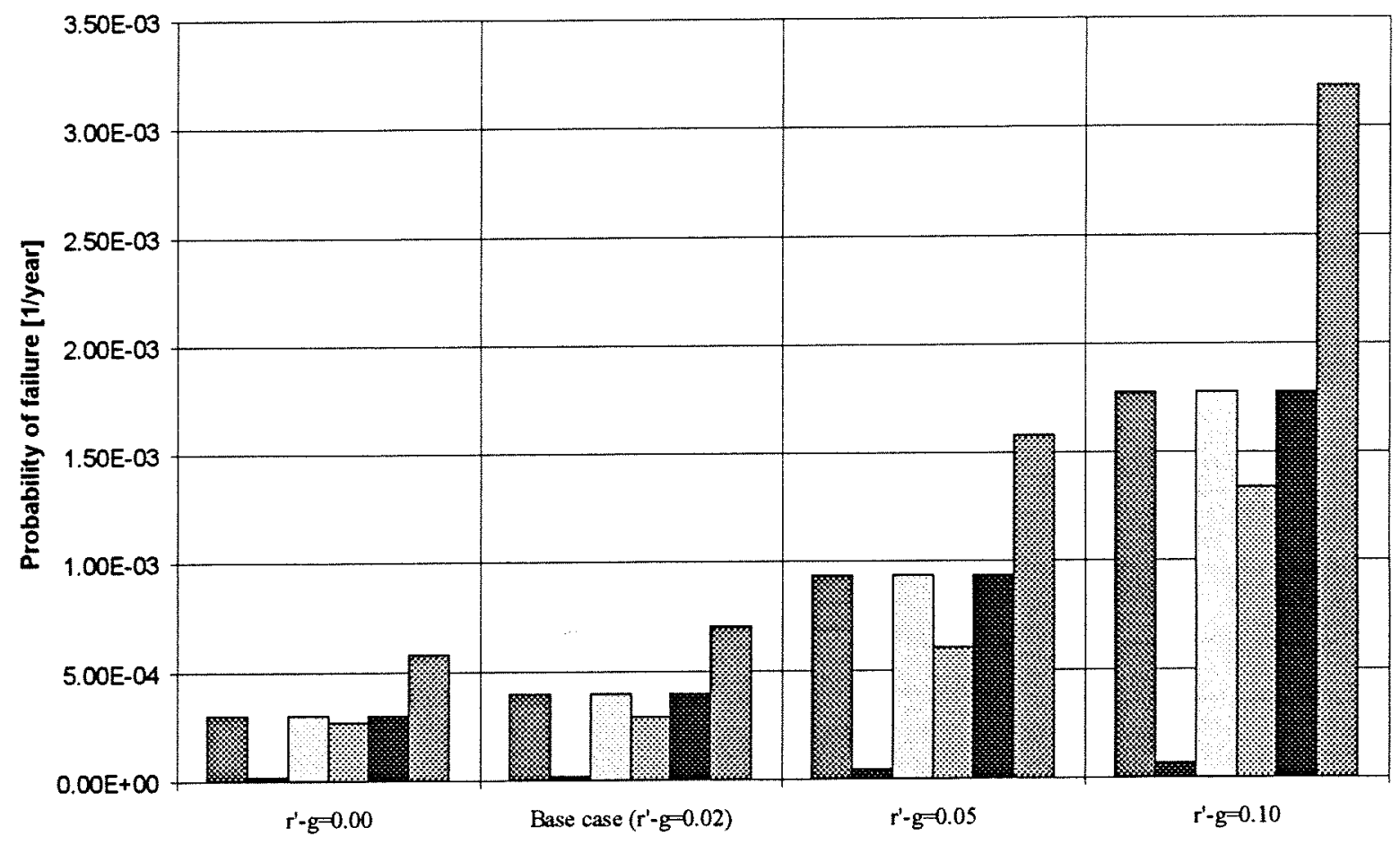

System probability of failure Sliding $\square$ Min. pressure Max. pressure Lower boundary 0 Lpper boundary

Figure 5.9: Individual probabilities of failure (run 1 through 4) 


\subsection{Optimization with two random variables for ultimate limit states}

\subsubsection{Introduction}

In this section the optimization of the caisson design is carried out using the distribution of the design wave height and the yearly maximum water level. Only ultimate limit states are considered. The probability of failure is estimated using a Monte Carlo procedure (see annex III).

\subsubsection{Model input and results}

A short overview of the model input and the results is given in table 5.4. A more extensive overview is given in annexes IV and VIII.

\begin{tabular}{|l|l|l|l|l|l|}
\hline \multirow{2}{*}{ Run number } & \multicolumn{2}{|l|}{ Input } & \multicolumn{2}{l|}{ Results (optimal design) } \\
\cline { 2 - 7 } & $\begin{array}{l}\text { Water depth in } \\
\text { front of the } \\
\text { caisson }\end{array}$ & $\begin{array}{l}\text { Design } \\
\text { wave height }\end{array}$ & $\begin{array}{l}\text { Caisson } \\
\text { height }\end{array}$ & $\begin{array}{l}\text { Caisson } \\
\text { width }\end{array}$ & $\begin{array}{l}\text { Probability of } \\
\text { failure (ULS) }\end{array}$ \\
\cline { 2 - 7 } & {$[\mathrm{m}]$} & $\mathrm{Gm}$ & {$[\mathrm{m}]$} & {$[\mathrm{m}]$} & {$\left[10^{-4} /\right.$ year] } \\
\hline 2 (base case) & 15 & $\mathrm{G}(4.30 ; 0.42)$ & 22.50 & 19.98 & 3.97 \\
\hline 7 & $\mathrm{~N}(12.15,1)^{365}$ & 22.58 & 20.18 & 4.34 \\
\hline
\end{tabular}

Table 5.4: Input and results for optimization with two random variables

Figure 5.10 shows the optimal height and width of the caisson. Figure 5.11 shows the individual probabilities of failure.

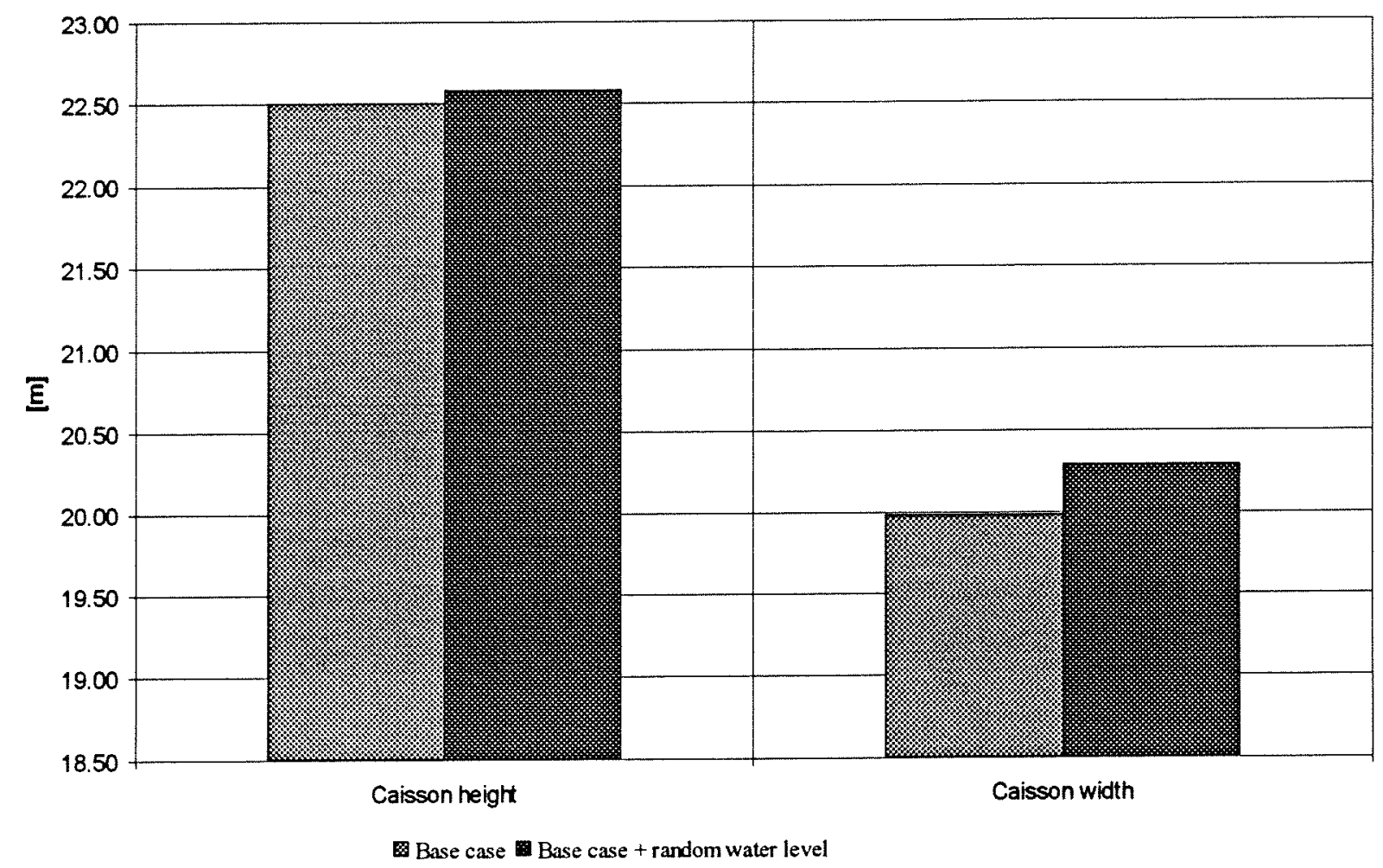

Figure 5.10: Optimal height and width of the caisson (run 2 and 7) 


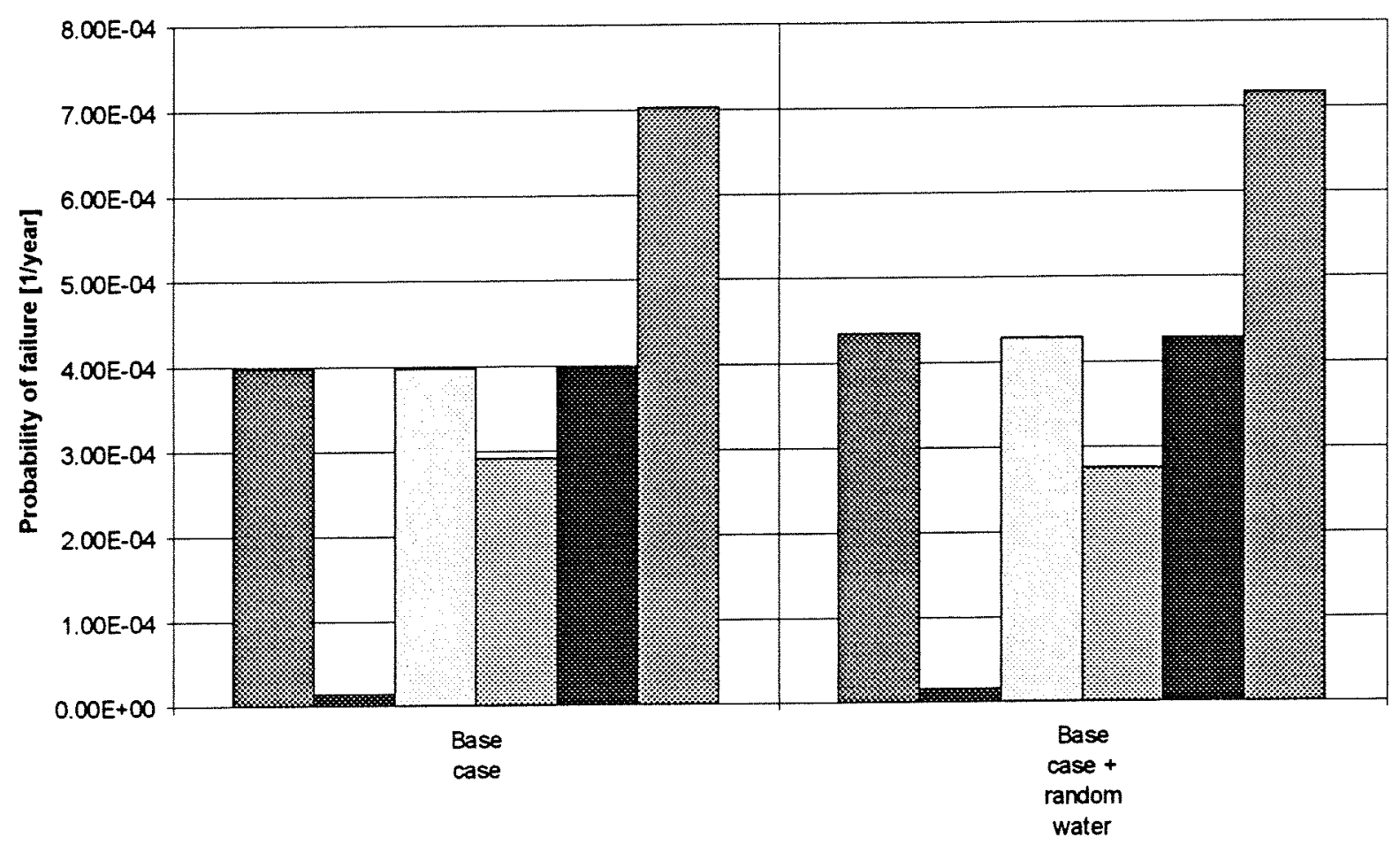

System probability of failure

Figure 5.11: Individual failure probabilities (run 2 and 7)

Due to the use of a distribution for the water level, extra uncertainty is introduced which increases the probability of failure. Comparison of the results of run 2 and run 7 shows that apparantly in that case the new optimum design is the result of a balancing process between a larger caisson and an increased probability of failure. Sliding failure seems to be of no importance for the total probability of failure of the caisson (see section 5.4.3).

The height/width ratios are in the range of 1.10 to 1.15 . The use of two random variables results in a slightly wider caisson compared to the case with one random variable (see annex VIII). 


\subsection{Influence of wave transmission on the optimal design}

\subsubsection{Introduction}

The main function of the breakwater is in this report defined as protection against wave action (section 2.2). The breakwater fails to fulfill this function if it collapses (ultimate limit state) or if it fails to prevent wave penetration in the harbour basin sufficiently (serviceability limit state). Wave penetration can be caused by refraction and/or diffraction through the entrance channel or by wave transmission.

In the previous sections the optimization was concerned with the stability of the breakwater only. Its functionality was not included. In this section the influence of wave transmission will be examined. The reliability function for excessive wave transmission is given in section 5.3.3.

\subsubsection{Model input and results}

A short overview of the used input and the results of the optimization is given in table 5.5. A more extensive overview is given in annexes IV and IX.

\begin{tabular}{|c|c|c|c|c|c|c|}
\hline \multirow{3}{*}{$\begin{array}{l}\text { Run } \\
\text { number }\end{array}$} & \multicolumn{2}{|l|}{ Input } & \multicolumn{4}{|c|}{ Results (optimal design) } \\
\hline & $\begin{array}{l}\text { Daily max. } \\
\text { water depth } \\
\text { in front of } \\
\text { the caisson }\end{array}$ & $\begin{array}{l}\text { Daily max. } \\
\text { sign. wave } \\
\text { height }\end{array}$ & $\begin{array}{l}\text { Caisson } \\
\text { height }\end{array}$ & $\begin{array}{l}\text { Caisson } \\
\text { width }\end{array}$ & $\begin{array}{l}\text { Probability } \\
\text { of failure } \\
\text { (SLS) }\end{array}$ & $\begin{array}{l}\text { Probability } \\
\text { of failure } \\
\text { (ULS) }\end{array}$ \\
\hline & [m] & [m] & [m] & [m] & [1/day] & [10-4/year] \\
\hline 2 (base) & - & - & 22.50 & 19.98 & - & 3.97 \\
\hline 8 & 15 & $G(0.91 ; 0.21)$ & 22.56 & 19.45 & 0.00 & 6.16 \\
\hline 9 & $N(12.15,1)$ & $G(0.91 ; 0.21)$ & 22.67 & 19.85 & 0.00 & 6.09 \\
\hline
\end{tabular}

Table 5.5: Input and results for optimization including wave transmission

The optimal height and width of the caisson are given in figure 5.12. The individual failure probabilities are shown in figure 5.13 . 


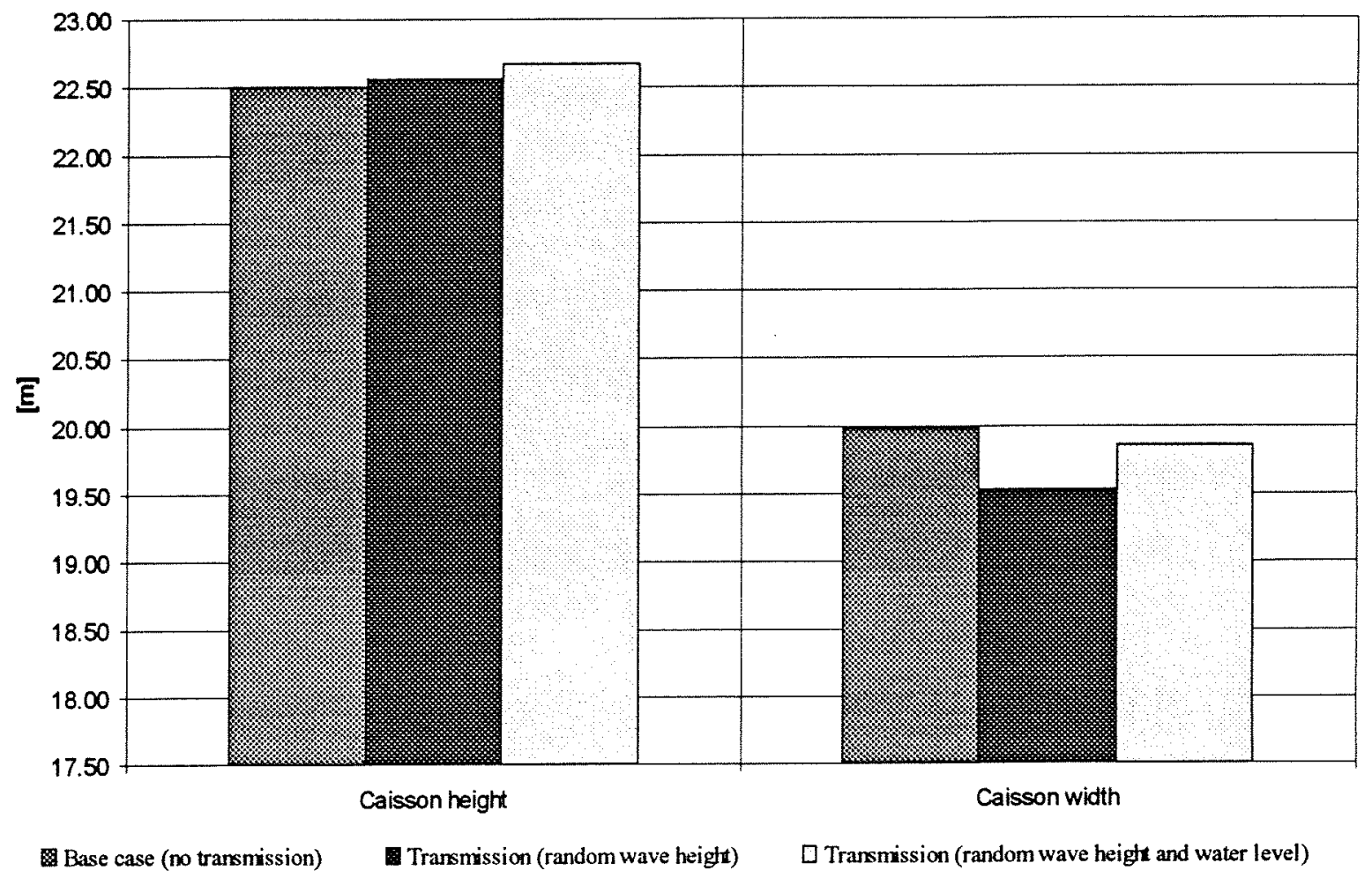

Figure 5.12: Optimal height and width of the caisson (run 2, 8 and 9)

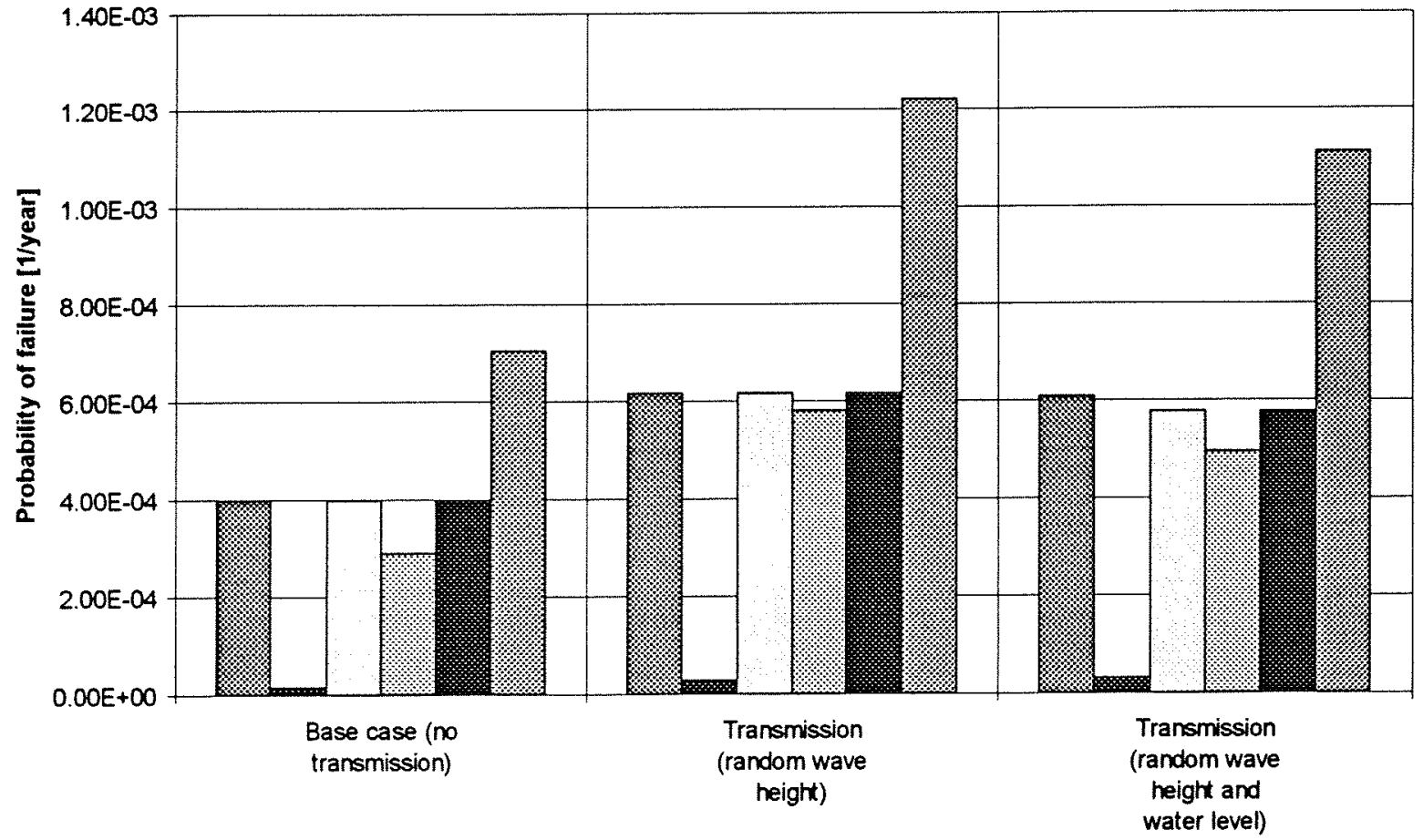

System probability of failure $\mathrm{x}$ Sliding $\square$ Min pressure

Figure 5.13: Individual failure probabilities (run 2, 8 and 9) 
Apparently it is economical in this situation to heighten the caisson further to a height at which SLS failure does not occur. Increasing the height of the caisson causes the effective weight of the caisson to increase as well. Since the failure mode "minimum pressure on the sea side" is decisive for ULS failure, an increase of the effective weight due to extra height causes a decrease of the required width of the caisson. Including uncertainty in the water level further increases the required caisson height, while in this case also the optimal width increases. This last effect can probably be declared from the fact that introduction of a random water level leads already to wider caissons for ULS only (see section 5.5).

In this case sliding failure seems to be of no importance to the stability of the caisson, as observed in other calculations as well. In general the found caisson dimensions are wider than expected with the design rules of PIANC [PIANC, 1976].

\subsection{Concluding remarks}

Including the risk component in the cost function tends to shift the optimum design to narrower caissons than in the case where only the construction costs were included (chapter 4). Possibly this is caused by the fact that by including the risk, one mechanism can be "favoured" for consuming the most part of the accepted probability of failure. In general this will be the mechanism which is most expensive to strengthen the caisson against. With the reliability functions chosen in this study, the most economic choice is the failure mode "rotation of the caisson". This failure mode is strongly influenced by the width of the caisson which is the most expensive design variable (see section 5.4.3).

In general, the optimal caisson designs found in this study consist of caissons which are considerably wider than predicted by PIANC [PIANC, 1976] (annex I). However, it should be noted that the design rules of PIANC are given as minimum requirements and that the dimensions found by optimization in principle fit into the design rules. The wider caissons could also be caused by the requirement of positive effective soil stress on the sea side. In general this requirement is quite strict. In this study the failure mode "too low pressure on sea side" is in general decisive which means that this mechanism influences the caisson dimensions strongly. 


\section{$6 \quad$ Conclusions and outline of future work}

\subsection{Results of this study}

In this study a preliminary optimization model has been developed for vertical breakwaters. This model is able to calculate the optimal height and width of a caisson, given the geometry of the rest of the structure and given the hydraulic and geotechnical boundary conditions. It promises to be a good starting point for the development of a more advanced model.

Optimization of the construction costs in general leads to an almost constant height/width ratio. However, the results of a complete optimization (taking into account the capitalized risk) shows that an optimization of the construction costs alone is in general not sufficient to find an optimal design.

Calculations made with the numerical model show that in this study in general one failure mode (rotation failure) almost completely determines the system probability of failure. This can be declared from the fact that this failure mode is mostly influenced by the caisson width. It can be shown that in the chosen caisson cross section it is considerably more expensive to increase the width than it is to increase the height of the caisson. It seems that an optimum is found by balancing a decrease of the most expensive design variable against an increased risk and an increase of the "cheapest" design variable.

Optimization with inclusion of wave transmission shows that this failure mode tends to increase the height of the caisson. Consequently the effective weight of the caisson is increased, causing a smaller required width of the caisson.

In general the results of the optimizations show wider caissons than predicted by the design rules of PIANC [PIANC, 1976]. Two reasons are found which could declare this:

- $\quad$ PIANC gives minimum requirements for the caisson dimensions. Dependent on the situation wider caissons might be necessary;

- Rotation failure is in this study defined as the situation in which the caisson loses contact with the subsoil on the sea side of the caisson. This definition is very strict and could result in optimal caisson dimensions with a larger width.

The biggest problem when optimizing a breakwater design seems to be obtaining reliable input for the cost variables. Contact with experienced practitioners could probably solve this problem.

The current model needs further extension and testing. An outline of this work is given in the next section. 


\subsection{Outline of future work}

The model described in this study should be viewed as a first step towards a more complete optimization procedure for vertical breakwaters. Several extensions and improvements are possible or even necessary. Some ideas are outlined below.

In this study the models which describe load and strength have been thoroughly simplified. Including more advanced models for load and strength is needed to improve the model.

A rectangular caisson without a crown wall has been used in this study. In general, a crown wall will be included in the design. Furthermore the costs of the caisson should be weighed against the costs of the rubble foundation. These considerations lead to at least two new design variables:

- The depth in front of the caisson (d);

- The height of the crown wall with respect to the rest of the caisson.

The calculations made with the numerical model show that inclusion of more random variables tends to increase the dimensions of the breakwater as well as the optimal probability of failure. Taking into account more random variables is possible with the current model. Calculations should be carried out to examine the influence of several random variables.

The ratio between significant wave height and individual wave height (design wave height) is in this study chosen as a fixed value. In fact, the calculations should be based on two distributions for the wave height:

- A long term distribution of the significant wave height;

- A short term distribution of the individual wave height conditional to the significant wave height.

Ongoing research considering the influence of statistical and model uncertainty shows that these uncertainties influence the optimal design [van Gelder, 1996; van Gelder et al., 1997]. Furthermore the influence of uncertainties in the cost estimates has been examined for the case of dikes by [Slijkhuis et al., 1997]. In both cases research shows that the influence of these uncertainties should not be underestimated. The optimization model for vertical breakwaters could be improved by including these uncertainties. 


\section{References}

1. Benjamin, J.R; C.A. Cornell

Probability, Statistics and Decision for Civil Engineers

McGraw-Hill Book Company

New York, 1970

2. Bijker, E.W; J.F. Agema, J.F; J.J. van Dijk; H. Ligteringen; H.F. Burcharth; J. Ploeg

Tripoli Breakwater Damage, report technical investigation team

Delft University of Technology

Delft, 1981

3. CUR research committee E10 "Risk analysis"

Risk analysis in civil engineering, Vol. 1: probabilistic design in theory

(in Dutch, contains summary in English)

CUR (Centre for Civil Engineering Research and Codes)

Gouda, 1997

4. Dalsgaard Sørensen, J; H.F. Burcharth

Implementation of safety in the design

Draft report of sub-group $D$

PIANC WG 28

Aalborg, 1996

5. Dantzig, D. van; J. Kriens

The economic decision problem concerning the security of the Netherlands against storm surges (in Dutch)

In: Report of the Delta commitee, part 3

The Hague, 1960

6. Dean, R.G; R.A. Dalrymple

Water wave mechanics for engineers and scientists

Advanced Series on Ocean Engineering - Volume 2

World Scientific

Singapore, 1991

7. Delft University of Technology

Ennore coal project, India. Risk analysis and probabilistic modelling

Delft, 1995

8. Ditlevsen, O; H.O. Madsen

Structural reliability methods

John Wiley \& Sons

Chichester, 1996 
9. Edge, B.L; W.F. Baird; J.M. Caldwell; V. Fainweather (ed.); O.T. Magoon; D.D.Treadwell Failure of the breakwater at Port Sines, Portugal

American Society of Civil Engineers

New york, 1982

10. Gelder, P.H.A.J.M. van

How to deal with wave statistical and model uncertainties in the design of vertical breakwaters

Report for PROVERBS task 2-3 workshop September 1996, Grenoble

Delft, 1996

11. Gelder, P.H.A.J.M. van; J.K. Vrijling; H.G. Voortman

Probabilistic analysis of wave transmission due to overtopping of vertical breakwaters

In: Proceedings $1^{\text {st }}$ overall workshop PROVERBS, Papers task 2,3 and 4

Mast III - PROVERBS

Las Palmas, 1997

12. Goda, $Y$.

Re-analysis of Laboratory Data on Wave Transmission over Breakwaters

Report of the Port and Harbour Research Institute, vol. 8 No. 3

1969

13. Goda, $Y$.

Random Seas and Design of Maritime Structures

University of Tokyo Press

Tokyo, 1985

14. Groot, M.B. de, H.J. Luger, H.G. Voortman

Description of failure modes

Delft Geotechnics, Delft University of Technology

prepared for: MAST-III/PROVERBS

Delft, 1996

15. HR Wallingford, Leichtweiss Institute, University of Plymouth, Delft Hydraulics

Notations

prepared for: MAST-III/PROVERBS

Wallingford, 1996

16. Johnson, N.L; S. Kotz, N. Balakrishnan

Continuous univariate distributions, volume 1 (second edition)

Wiley series in probability and mathematical statistics

New York, 1994 
17. Madsen, H.O; S. Krenk; N.C. Lind

Methods of structural safety

Prentice Hall inc.

London, 1986

18. Oumeraci, $\mathrm{H}$.

Review and analysis of vertical breakwaters - lessons learned

Coastal Engineering Vol. 22, page 3-30

Elsevier Science

Amsterdam, 1994

19. Permanent International Association of Navigation Congresses (PIANC)

Final report of the international commission for the study of waves

Brussels, 1976

20. Press, W.H; B.P. Flannery, S.A. Teukolsky, W.T. Vetterling

Numerical Recipes in Pascal, The art of Scientific Computing

Cambridge University Press

Cambridge, 1990

21. Slijkhuis, K.A.H; P.H.A.J.M. van Gelder; J.K. Vrijling

Optimal dike height under statistical, construction and damage uncertainty In: Proceedings $1^{\text {st }}$ overall workshop PROVERBS, Papers task 2, 3 and 4 Mast III - PROVERBS

Las Palmas, 1997

22. Takahashi, S

Design of Vertical Breakwaters

Reference Document No. 34

Port and Harbour Research Institute

Tokyo, 1996

23. Vrijling, J.K.

Definition of an acceptable probability of failure of a caisson breakwater In: Proceedings $1^{\text {st }}$ overall workshop PROVERBS, Papers task 2, 3 and 4 Mast III - PROVERBS

Las Palmas, 1997

24. Vrijling, J.K, W. van Hengel, R.J. Houben

A framework for risk evaluation

Elsevier, Journal of hazardous materials, 245-261

Amsterdam, 1995 
25. Wiegel, R.L

Oceanographical Engineering

Prentice Hall inc.

London, 1964

26. Zandvoort, C.

Turbo Pascal in practice, version 7.0 (in dutch)

Uitgeverij Pim Oets

Amsterdam, 1996 
Annex I: Design rules for vertical breakwaters derived by PIANC 

The international commission for the study of waves gives in its final report [PIANC, 1976] some rules of thumb for the preliminary design of vertical breakwaters. An overview of these rules for a fixed water level is given in figure I.1.

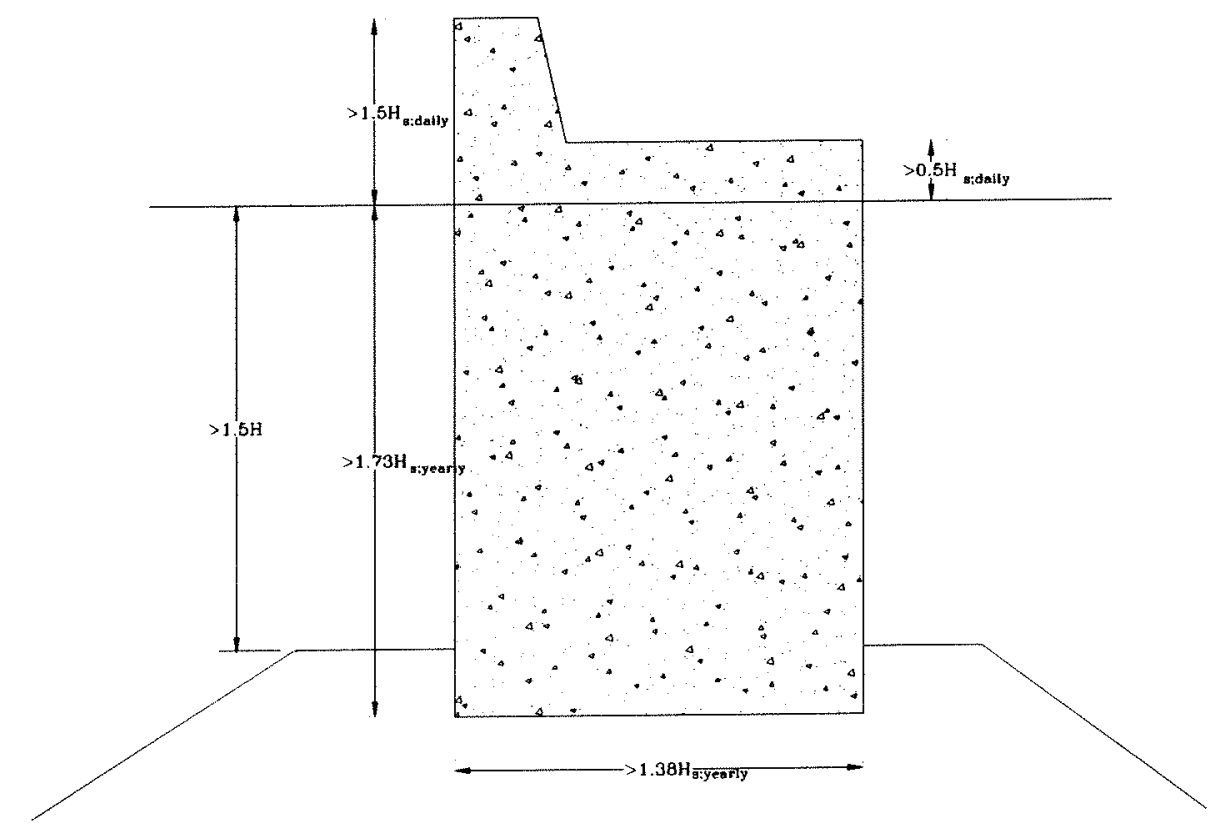

Figure I.1: Overview of PIANC design rules (no tidal variation of water level)

Considering the distributions of the daily and yearly maximum significant wave height (chapter 5), the daily wave height can be expressed as:

$$
\mathrm{H}_{\mathrm{s} ; \mathrm{daily}}=\frac{\mathrm{H}_{\mathrm{s} ; \mathrm{yearly}}}{2.4}
$$

Using (I.1) the height/width ratio according to PIANC equals:

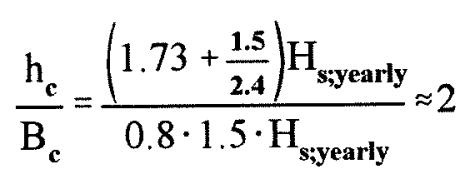


Annex II: Determination of the relevant pressure distributions under the caisson 


\section{Selection of decisive failure modes}

$$
\begin{array}{ll}
\text { Input } & \gamma_{\mathrm{w}}:=10.25 \cdot 10^{3} \cdot \frac{\text { newton }}{\mathrm{m}^{3}} \\
\mathrm{~h}_{\mathrm{c}}:=17 \cdot \mathrm{m} & \\
\mathrm{d}_{\mathrm{c}}:=0 \cdot \mathrm{m} & \gamma_{\mathrm{c}}=21 \cdot 10^{3} \cdot \frac{\text { newton }}{\mathrm{m}^{3}} \\
\mathrm{~B}_{\mathrm{c}}:=25 \cdot \mathrm{m} & \mathrm{H}_{\mathrm{d}}:=10 \cdot \mathrm{m} \\
\phi:=30 \cdot \mathrm{deg} & \mathrm{r}=1 \\
\mathrm{f}:=\tan \left(\frac{2}{3} \cdot \phi\right) & \sigma_{\max }:=500 \cdot 10^{3} \cdot \frac{\text { newton }}{\mathrm{m}^{2}}
\end{array}
$$

Breakwater freeboard: $\quad R_{c}\left(h_{c}, d_{,} d_{c}\right):=h_{c}-d-d_{c}$

Effective weight: $\quad W_{\text {eff }}\left(h_{c}, B_{c}, d_{,} d_{c}\right)=B_{c} \cdot\left[h_{c} \cdot\left(\gamma_{c}-\gamma_{w}\right)+\max \left(\left(\begin{array}{c}R_{c}\left(h_{c}, d_{,} d_{c}\right) \cdot \gamma_{w} \\ 0\end{array}\right)\right)\right]$

\section{Wave forces (hydrostatic approach)}

Crest elevation: $\eta\left(\mathrm{H}_{\mathrm{d}}\right):=\frac{1+\mathrm{r}}{2} \cdot \mathrm{H}_{\mathrm{d}}$

Pressures: $\quad \mathrm{p}_{1}\left(\mathrm{H}_{\mathrm{d}}\right):=\gamma_{\mathrm{w}} \cdot \eta\left(\mathrm{H}_{\mathrm{d}}\right)$

$$
\begin{aligned}
& \mathrm{p}_{3}\left(\mathrm{H}_{\mathrm{d}}\right)=\mathrm{p}_{1}\left(\mathrm{H}_{\mathrm{d}}\right) \\
& \mathrm{p}_{4}\left(\mathrm{H}_{\mathrm{d}}\right)=\mathrm{if}\left[\mathrm{R}_{\mathrm{c}}\left(\mathrm{h}_{\mathrm{c}}, \mathrm{d}_{,} \mathrm{d}_{\mathrm{c}}\right) \leq 0, \mathrm{p}_{1}\left(\mathrm{H}_{\mathrm{d}}\right), \text { if }\left[\mathrm{R}_{\mathrm{c}}\left(\mathrm{h}_{\mathrm{c}}, \mathrm{d}_{,} \mathrm{d}_{\mathrm{c}}\right)>\eta\left(\mathrm{H}_{\mathrm{d}}\right), 0,\left(1-\frac{\mathrm{R}_{\mathrm{c}}\left(\mathrm{h}_{\mathrm{c}}, \mathrm{d}_{,} \mathrm{d}_{\mathrm{c}}\right)}{\eta\left(\mathrm{H}_{\mathrm{d}}\right)}\right) \cdot \mathrm{p}_{1}\left(\mathrm{H}_{\mathrm{d}}\right)\right]\right]
\end{aligned}
$$

Wave forces: $\quad F_{1}\left(h_{c}, d_{,} d_{c}, H_{d}\right):=\max \left[\left(\left[\frac{1}{2} \cdot\left(p_{1}\left(H_{d}\right)+p_{4}\left(H_{d}\right)\right) \cdot \min \left(\begin{array}{c}R_{c}\left(h_{c}, d, d_{c}\right) \\ \eta\left(H_{d}\right)\end{array}\right)\right)\right]\right.$

$$
\begin{aligned}
& F_{2}\left(h_{c}, d_{,} d_{c}, H_{d}\right)=p_{1}\left(H_{d}\right) \cdot \min \left(\left(\begin{array}{c}
h_{c} \\
d+d_{c}
\end{array}\right)\right) \\
& F_{u}\left(h_{c}, B_{c}, d_{,} d_{c}, H_{d}\right):=\frac{1}{2} \cdot p_{3}\left(H_{d}\right) \cdot B_{c}
\end{aligned}
$$


Lever arms: $\quad 1_{1}\left(d_{,} d_{c}, h_{c}, H_{d}\right):=d+d_{c}+\frac{\left(p_{1}\left(H_{d}\right)+2 \cdot p_{4}\left(H_{d}\right)\right) \cdot \min \left(\left(\begin{array}{c}R_{c}\left(h_{c}, d, d_{c}\right) \\ \eta\left(H_{d}\right)\end{array}\right)\right)}{3 \cdot\left(p_{1}\left(H_{d}\right)+p_{4}\left(H_{d}\right)\right)}$

$$
\begin{aligned}
& 1_{2}\left(d_{,} d_{c}, h_{c}\right):=\frac{1}{2} \cdot \min \left(\left(\begin{array}{l}
h_{c} \\
d+d_{c}
\end{array}\right)\right) \\
& 1_{u}\left(B_{c}\right):=\frac{B_{c}}{6}
\end{aligned}
$$

Moment of horizontal forces:

$$
M_{H}\left(h_{c}, d_{,} d_{c}, H_{d}\right):=1_{1}\left(d_{,} d_{c}, h_{c}, H_{d}\right) \cdot F_{1}\left(h_{c}, d_{,} d_{c}, H_{d}\right)+1_{2}\left(d_{,} d_{c}, h_{c}\right) \cdot F_{2}\left(h_{c}, d_{,}, d_{c}, H_{d}\right)
$$

Width required against sliding

$$
B_{c s l i d}\left(h_{c}, d_{,} d_{c}, H_{d}\right):=\frac{F_{1}\left(h_{c}, d_{,} d_{c}, H_{d}\right)+F_{2}\left(h_{c}, d_{,} d_{c}, H_{d}\right)}{f \cdot\left[h_{c} \cdot\left(\gamma_{c}-\gamma_{w}\right)+\max \left(\left(\begin{array}{c}
R_{c}\left(h_{c}, d, d_{c}\right) \cdot \gamma_{w} \\
0
\end{array}\right)-\frac{p_{3}\left(H_{d}\right)}{2}\right]\right.}
$$

Width required to keep whole bottom under pressure:

$$
B_{c m i n}\left(h_{c}, d_{,} d_{c}, H_{d}\right)=\sqrt{\frac{6 \cdot M_{H}\left(h_{c}, d_{,} d_{c}, H_{d}\right)}{\left[h_{c} \cdot\left(\gamma_{c}-\gamma_{w}\right)+\max \left(\left(\begin{array}{c}
R_{c}\left(h_{c}, d_{,} d_{c}\right) \cdot \gamma_{w} \\
0
\end{array}\right)\right]-p_{3}\left(H_{d}\right)\right.}}
$$

Width required to prevent exceedance of the maximum pressure under the assumption of a trapezoidal pressure distribution:

$$
B_{c \operatorname{maxl}}\left(h_{c}, d_{,} d_{c}, H_{d}\right)=\sqrt{\frac{6 \cdot M_{H}\left(h_{c}, d, d_{c}, H_{d}\right)}{\sigma_{\max }-\left[h_{c} \cdot\left(\gamma_{c}-\gamma_{w}\right)+\max \left(\left(\begin{array}{c}
R_{c}\left(h_{c}, d_{,} d_{c}\right) \cdot \gamma_{w} \\
0
\end{array}\right)\right]\right.}}
$$

Width required to prevent exceedance of the maximum pressure under the assumption of a triangular pressure distribution:

$$
\begin{aligned}
& \alpha\left(h_{c}, d, d_{c}, H_{d}\right):=\frac{2 \cdot h_{c} \cdot \gamma_{c}-2 \cdot\left(d+d_{c}\right) \cdot \gamma_{w}-p_{3}\left(H_{d}\right)}{\sigma_{\max }} \\
& B_{c \max 2}\left(h_{c}, d_{,} d_{c}, H_{d}\right)=\sqrt{\frac{M_{H}\left(h_{c}, d, d_{c}, H_{d}\right)}{\left[\frac{1}{2} \cdot \sigma_{\max } \cdot \alpha\left(h_{c}, d, d_{c}, H_{d}\right) \cdot\left(\frac{1}{2}-\frac{1}{3} \cdot \alpha\left(h_{c}, d_{,} d_{c}, H_{d}\right)\right]-\frac{p_{3}\left(H_{d}\right)}{12}\right]}}
\end{aligned}
$$


Required width as a function of the design wave height:

$\mathrm{h}_{\mathrm{c}}:=15 \cdot \mathrm{m}, 15.1 \cdot \mathrm{m} . .25 \cdot \mathrm{m}$

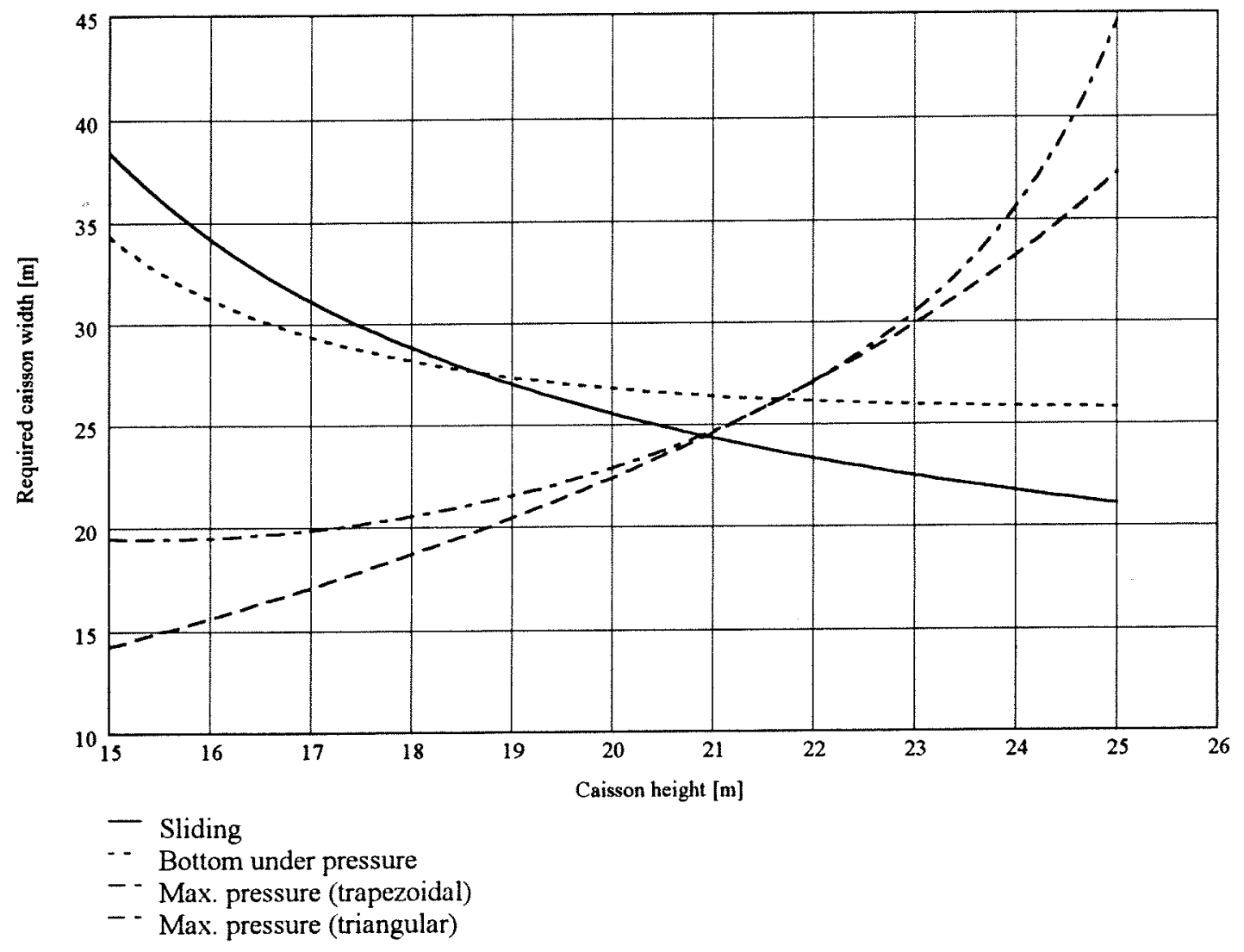

Check if trapezoidal pressure distribution is valid:

Calculate stress on the sea side with the widths in the previous graph as input, assuming a trapezoidal pressure distribution.

Stress on the sea side calculated with required width against sliding:

$\sigma_{\text {seaslid }}\left(h_{c}, d, d_{c}, H_{d}\right):=h_{c} \cdot \gamma_{c}-\left(d+d_{c}\right) \cdot \gamma_{w}-\frac{6 \cdot M_{H}\left(h_{c}, d, d_{c}, H_{d}\right)}{B_{c s l i d}\left(h_{c}, d, d_{c}, H_{d}\right)^{2}}-p_{3}\left(H_{d}\right)$

Stress on the sea side calculated with required width such that $\sigma$. sea $>=0$ (should be exactly 0 !):

$\sigma_{\text {seamin }}\left(h_{c}, d, d_{c}, H_{d}\right):=h_{c} \cdot \gamma_{c}-\left(d+d_{c}\right) \cdot \gamma_{w}-\frac{6 \cdot M_{H}\left(h_{c}, d, d_{c}, H_{d}\right)}{B_{c m i n}\left(h_{c}, d_{,} d_{c}, H_{d}\right)^{2}}-p_{3}\left(H_{d}\right)$ 
Stress on the sea side calculated with required width such that max. pressure is not exceeded (assumption: trapezoidal press. distr.):

$\sigma_{\text {seamaxl }}\left(h_{c}, d, d_{c}, H_{d}\right):=h_{c} \cdot \gamma_{c}-\left(d+d_{c}\right) \cdot \gamma_{w}-\frac{6 \cdot M_{H}\left(h_{c}, d, d_{c}, H_{d}\right)}{B_{c m a x l}\left(h_{c}, d_{,} d_{c}, H_{d}\right)^{2}}-p_{3}\left(H_{d}\right)$

Stress on the sea side calculated with required width such that max. pressure is not exceeded (assumption: triangular pressure distribution) If this is valid, then $\sigma$. sea $<0$.

$\sigma_{\operatorname{seamax} 2}\left(h_{c}, d_{,} d_{c}, H_{d}\right):=h_{c} \cdot \gamma_{c}-\left(d+d_{c}\right) \cdot \gamma_{w}-\frac{6 \cdot M_{H}\left(h_{c}, d, d_{c}, H_{d}\right)}{B_{c \max 2}\left(h_{c}, d_{,} d_{c}, H_{d}\right)^{2}}-p_{3}\left(H_{d}\right)$

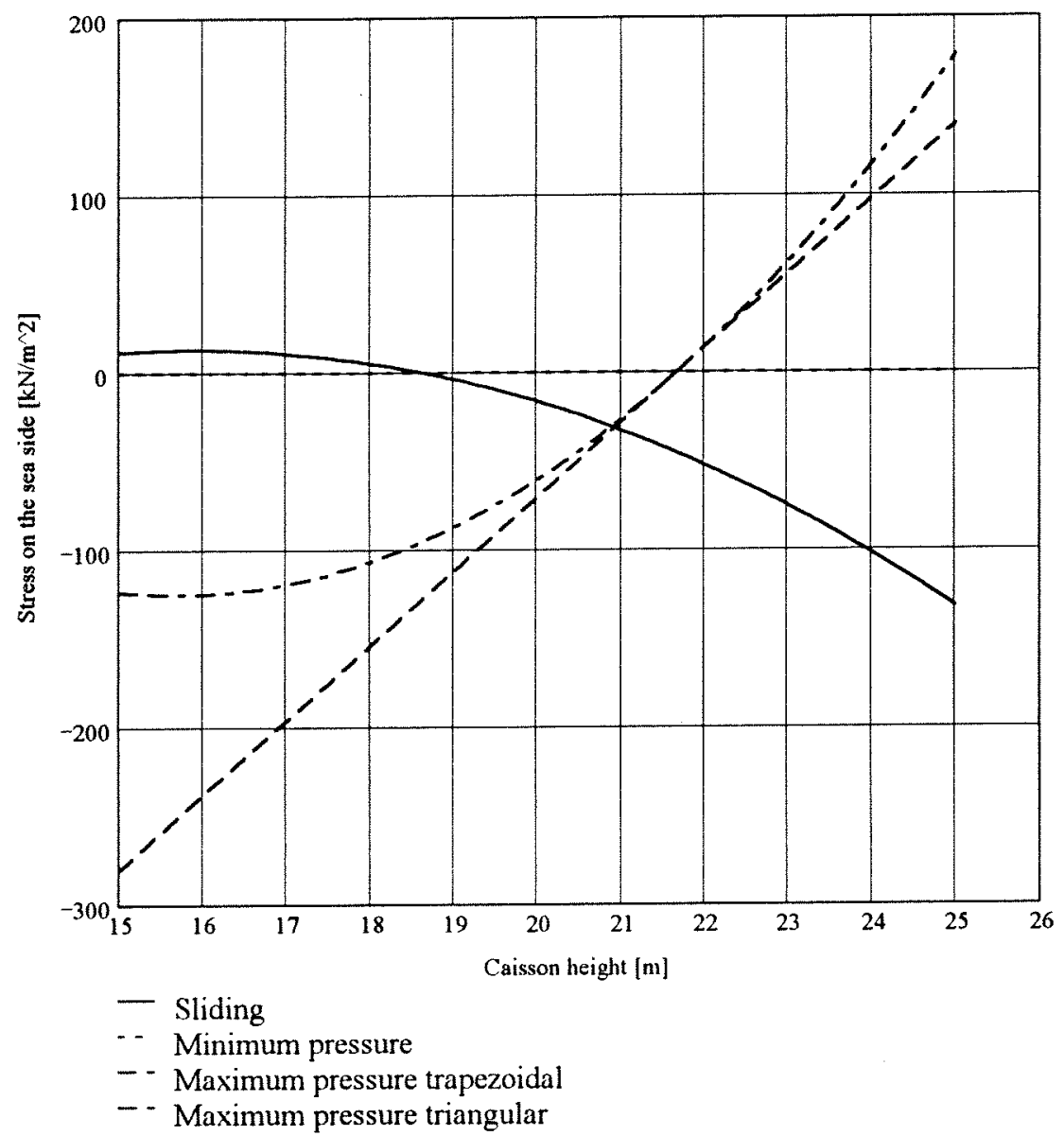

Observing the first graph shows that for caisson heights above $21.5 \mathrm{~m}$ the caisson width is supposed to be determined by max. pressure under a triangular pressure distribution. The second graph shows that in that case the pressure on the sea side is positive. Thus, the assumption of the triangular pressure distribution is not valid in this area.

The part where the assumption is correct, the required width is never determined by the triangular pressure distribution, as long as positive stress on the sea side is required. 
Annex III: Description of the program OPT_VBW 



\section{The model OPT_VBW}

\section{III.1 Introduction}

In general more then one random variables are involved in the design. Special procedures to calculate the probability of failure are needed in that case. For that reason the optimization procedure has been programmed in Turbo Pascal ${ }^{\$}$. The program is called OPT_VBW. This is an abbreviation of OPTimization of Vertical BreakWaters.

In section III.2 the overall scheme of the optimization procedure is given. Section III. 3 describes some technical details conceming the programming of the model. The input required for the model is shortly described in III.4. An overview of the generated output is given in section III.5. The calculation of wave forces is described in III.6. The used reliability functions are given in section III.7. Section III.8 introduces the method used for the calculation of the probability of failure. The minimization procedure is introduced in III.9. For the boundary conditions and the breakwater geometry, several distribution types are available in the model. An overview is given in III.10.

\section{III.2 Scheme of the optimization procedure}

The optimization procedure controls the whole program. It determines whether a new evaluation of the cost function is required. Once an evaluation of the cost function is made, first the probability of failure is calculated after which this value is used to determine the value of the cost function. An overview of the optimization procedure is given in figure III.1. 


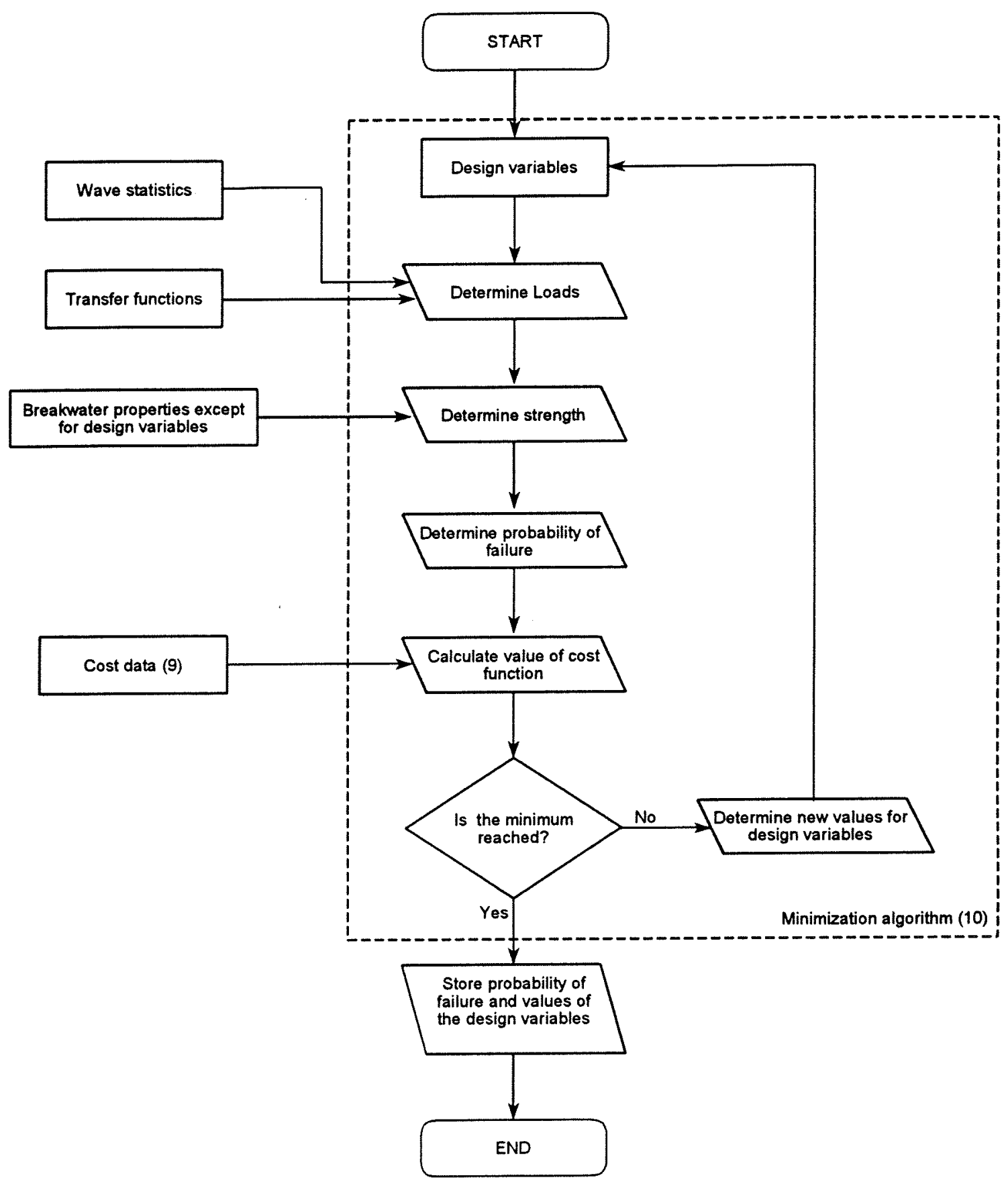

Figure III.1: Scheme of the optimization procedure 


\section{III.3 Program structure}

A very important requirement of the model is that future extensions and adjustments must be possible. To facilitate this the source code is split up in units. This is a method provided by Turbo Pascal to split up a program in separate files which can be linked together. Doing this in a proper way keeps the program structure clear and makes "recycling" of source code possible. A short description of the units in which OPT_VBW is split up is given in table III.1.

\begin{tabular}{|l|l|}
\hline Unit name & Description \\
\hline OPT_VBW & Main program \\
\hline INTERF & Controls the input and output processes \\
\hline CALC & Contains all the calculations which are written specifically for this model \\
\hline Z_FUNC & Contains reliability functions for all mechanisms \\
\hline STAT & $\begin{array}{l}\text { Contains three types of statistical functions: } \\
\text { Cumulative Distribution Functions; } \\
\text { Inverse Cumulative Distribution Functions; } \\
\text { Random generators. }\end{array}$ \\
\hline MATH & Contains mathematical operations not supported by standard Turbo Pascal \\
\hline SCREENS & Contains the layout of the input screens \\
\hline UTILS & Contains several utilities and predefined types \\
\hline CRT & $\begin{array}{l}\text { Standard unit of Turbo Pascal }{ }^{\otimes} \text {. Controls keyboard, screen and sound } \\
\text { operations }\end{array}$ \\
\hline DOS & Standard unit of Turbo Pascal ${ }^{\otimes}$. Controls disk and file handling operations \\
\hline
\end{tabular}

Table III.1: Description of program units

A scheme of the unit structure is given in figure III.3. An arrow from block $A$ to block $B$ means that $B$ uses one or more procedures from $A$. 


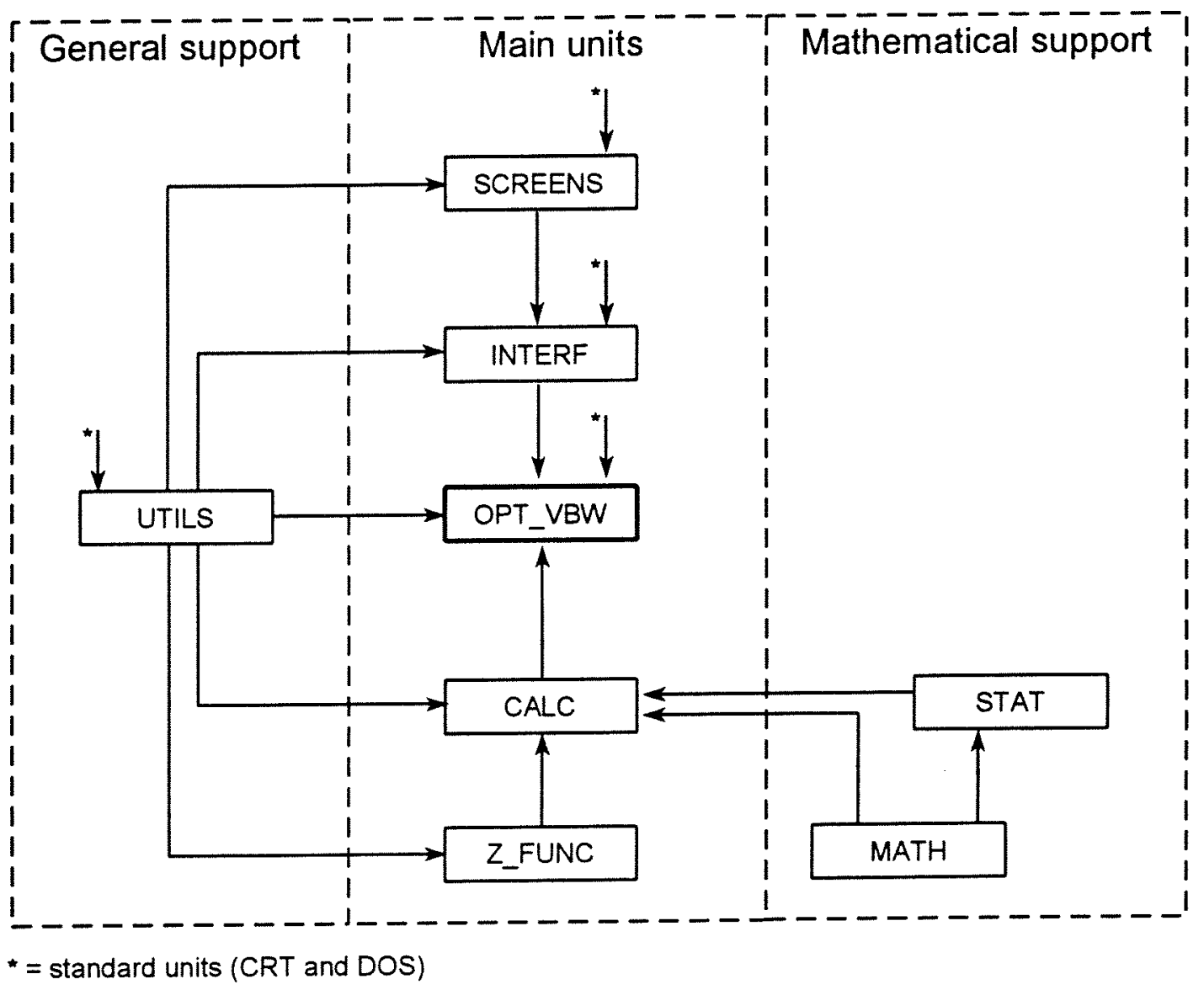

Figure III.2: Unit structure of the program OPT_VBW

In order to create batch-runs of the model, a separate program called OPT_INP is written. This program uses several units written for OPT_VBW. The unit structure of this program is given in figure III.4. 


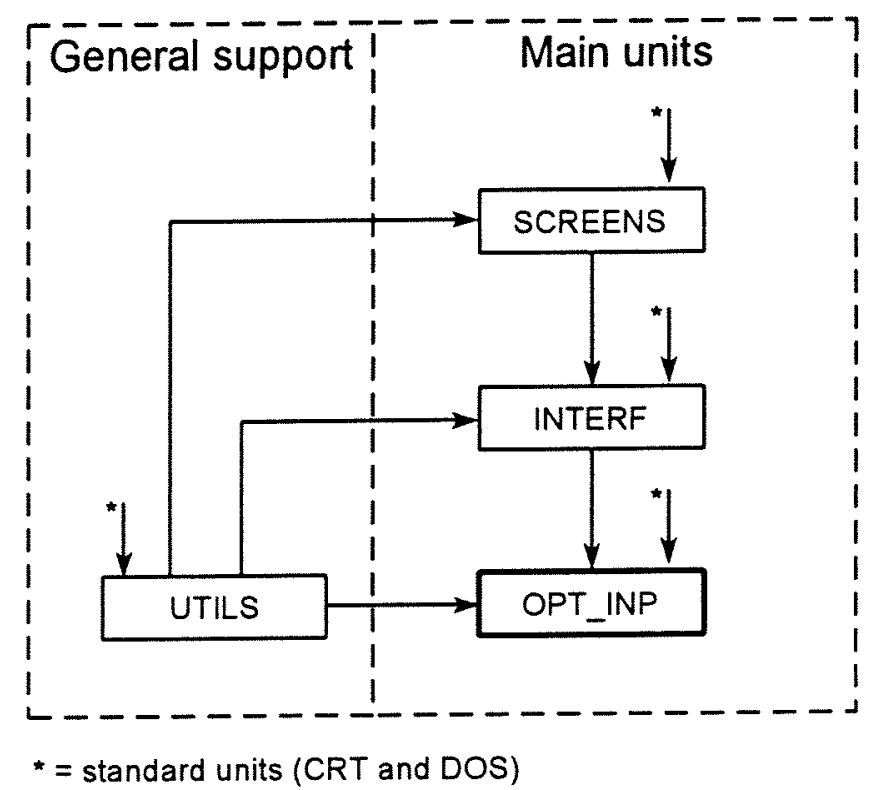

Figure III.3: Unit structure of the program OPT_INP

\section{III.4 Input for the program}

In the model, the user has to provide the breakwater geometry, the environmental conditions and the cost variables. The geometry and the environmental conditions can be considered random variables. Several distribution types are possible. An overview is given in section III.10. Reliability functions are included in the program and can not be altered by the user. The user has the possibility to switch mechanisms on or off. An overview of the available reliability functions is given in section III.7.

\section{III.5 Output generated by the program}

The model generates output files which contain the following:

- An echo of the used input;

- The starting point of the optimization;

- The end point of the optimization (optimal breakwater dimensions);

- Individual failure probabilities per used mechanism;

- Upper and lower boundaries for ULS failure (series system of mechanisms);

- System probability of ULS failure using MC-simulation;

- Probability of SLS failure (downtime percentage) using MC-simulation;

- Number of iterations needed to arrive at the minimum;

- Number of cost function evaluations needed to arrive at the minimum.

In case of batch runs this output is repeated for every single run. 


\section{III.6 Wave forces}

The wave forces are calculated by means of the hydrostatic approach (section 4.4). The formulae are repeated below.

An overview of the assumed pressure distribution is given in figure III.4.

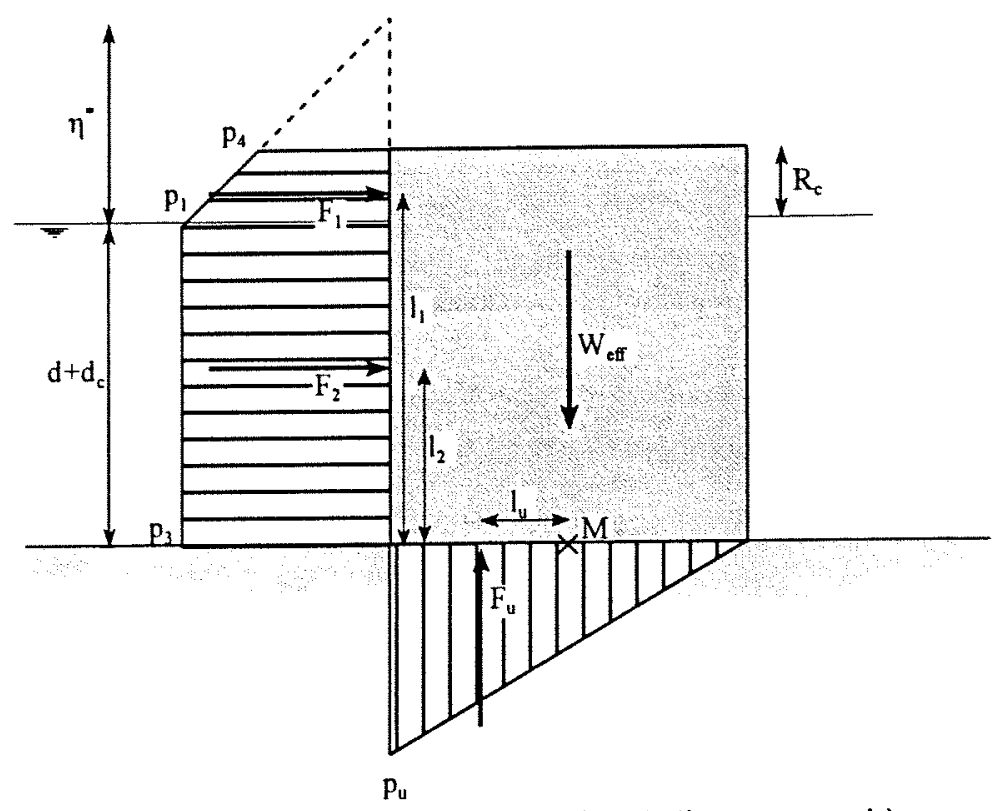

Figure III.4: Horizontal force on the caisson (hydrostatic approach)

The crest elevation of the reflected wave depends on the reflection coefficient and the incident wave height by:

$$
\eta^{*}=\frac{1+r}{2} \cdot H_{d}
$$


The wave pressures are given by:

$$
\begin{aligned}
& p_{1}=\gamma_{w} \eta^{*}=\gamma_{w} \frac{1+r}{2} H_{d} \\
& p_{3}=\gamma_{w} \eta^{*}=\gamma_{w} \frac{1+r}{2} H_{d} \\
& p_{4}= \begin{cases}{\left[1-\frac{R_{c}}{\eta^{*}}\right] p_{1}} & \text { for } 0 \leq R_{c} \leq \eta^{*} \\
0 & \text { for } R_{c}>\eta^{*}\end{cases} \\
& p_{u}=p_{3}
\end{aligned}
$$

In which:

$\gamma_{w}: \quad$ specific weight of the water $\left[\mathrm{kN} / \mathrm{m}^{3}\right]$;

$\eta^{*}: \quad$ crest elevation [m];

$\mathrm{H}_{\mathrm{d}}$ : design wave height [m];

$\mathrm{r}$ : reflection coefficient [-];

$\mathrm{R}_{\mathrm{c}}$ : crest height of the caisson [m].

Using these pressures, the wave forces can be calculated:

$$
\begin{aligned}
& F_{1}=\frac{1}{2}\left(p_{1}+p_{4}\right) \cdot \min \left\{\begin{array}{l}
R_{c} \\
\eta^{*}
\end{array}\right\} \\
& F_{2}=p_{1} \cdot\left(d+d_{c}\right) \\
& F_{u}=\frac{1}{2} p_{u} B_{c}
\end{aligned}
$$

The lever arms of the individual forces are given by:

$$
\begin{aligned}
& \mathrm{l}_{1}=d+d_{c}+\left(p_{1}+2 p_{4}\right) \cdot \min \left\{\begin{array}{c}
R_{c} \\
\eta^{*}
\end{array}\right\} \\
& l_{2}=\frac{1}{2} \cdot\left(d+d_{c}\right) \\
& l_{u}=\frac{B_{c}}{6}
\end{aligned}
$$


Combining (III.5) and (III.6) gives the tilting moments on the caisson. The tilting moment due to the horizontal forces is given by:

$$
\mathrm{M}_{\mathrm{H}}=1_{1} \mathrm{~F}_{1}+1_{2} \mathrm{~F}_{2}
$$

And the moment of the vertical forces by:

$$
\mathrm{M}_{\mathrm{v}}=1_{\mathrm{u}} \mathrm{F}_{\mathrm{u}}=\frac{1}{12} \mathrm{p}_{\mathbf{u}} \mathrm{B}_{\mathbf{c}}^{2}
$$

\section{III.7 Reliability functions}

Three mechanisms are included in the model. These mechanisms are:

- Wave transmission;

- $\quad$ Sliding of the caisson over the rubble foundation;

- Rotation failure of the caisson.

The reliability functions are derived in section 5.3. Only the end results are repeated below:

For transmission:

$$
\mathrm{Z}_{\text {transm }}=\mathrm{H}_{\text {s;acc }}-\mathrm{K}_{\mathrm{t}} \mathrm{H}_{\mathrm{s} ; \text { out }}
$$

In which $\mathrm{K}_{\mathrm{t}}$ is calculated according to [Goda, 1969].

For sliding:

$$
Z_{\text {slid }}=f\left(W_{e f f}-F_{u}\right)-F_{1}-F_{2}
$$

For rotation:

$$
Z_{\text {min }}=\sigma_{\text {sea }}=\frac{W_{\text {eff }}-F_{u}}{B_{c}}-\frac{M_{1 I}+M_{v}}{\frac{1}{6} B_{c}^{2}}
$$




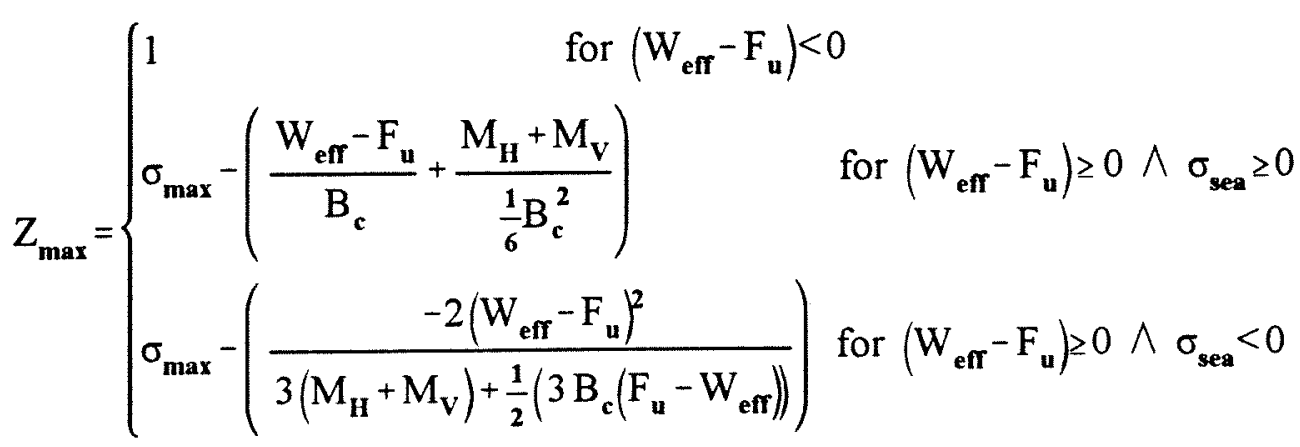

The complete reliability function for stability of the caisson:

$$
Z_{\mathrm{ULS}}=\min \left\{\begin{array}{l}
Z_{\text {slid }} \\
Z_{\min } \\
Z_{\max }
\end{array}\right\}
$$

\section{III.8 Calculation method for the probability of failure}

To calculate the value of the cost function for a certain breakwater geometry, the probability of failure for that geometry is needed. The failure probability is calculated by means of a Monte Carlo procedure (MC-simulation). This procedure automatically accounts for dependancy between mechanisms and/or variables. The long calculation times which are in general needed for MCsimulation are decreased by applying importance sampling.

\section{III.9 Minimization procedure}

The minimization procedure used is Powell's method [Press et al., 1990, page 331]. This method does not make use of derivatives of the cost function. In general methods which do make use of derivatives are more efficient. However, the results of the minimization of the construction costs (chapter 4) showed that the derivatives of the cost function are not always continuous. Therefore Powell's method was favoured above more advanced (and possibly faster) methods. Some faster methods will be tested in the future. 


\section{III.11 Overview of available distributions in OPT_VBW}

\section{III.11.1 Introduction}

Below an overview is given of all available distribution types in the program, including the corresponding formula. References are: [Benjamin and Cornell, 1970], [CUR, 1997], [Johnson et al, 1994].

III.11.2

Cumulative distribution functions

Gumbel:

$$
F_{\delta}(\xi)=\left(e^{-e^{-\frac{\xi-A}{B}}}\right)^{N}
$$

Rayleigh:

$$
F_{x}(\xi)=\left(e^{-2\left(\frac{\xi}{A}\right)^{2}}\right)^{N}
$$

Weibull:

$$
F_{x}(\xi)=\left(1-e^{\left(-\frac{\xi-A}{B}\right)^{C}}\right)^{N}
$$

Normal:

$$
F_{x}(\xi)=\left\{\begin{array}{l}
\left(1-\frac{1}{2}\left(1+a_{1}\left(\frac{x-A}{B}\right)+a_{2}\left(\frac{x-A}{B}\right)^{2}+a_{3}\left(\frac{x-A}{B}\right)^{3}+a_{4}\left(\frac{x-A}{B}\right)^{4}\right)^{-4}\right)^{N} \text { for } \frac{x-A}{B} \geq 0 \\
\left(\frac{1}{2}\left(1+a_{1}\left(-\frac{x-A}{B}\right)+a_{2}\left(-\frac{x-A}{B}\right)^{2}+a_{3}\left(-\frac{x-A}{B}\right)^{3}+a_{4}\left(-\frac{x-A}{B}\right)^{4}\right)^{-4}\right)^{N} \text { for } \frac{x-A}{B}<0
\end{array}\right.
$$

In which:

$a_{1}=0.196854$

$a_{2}=0.115194$

$a_{3}=0.000344$

$a_{4}=0.019527$ 
Lognormal:

$F_{x}(\xi)=\left\{\begin{array}{l}\left(1-\frac{1}{2}\left(1+a_{1}\left(\frac{\ln (x-C)-A}{B}\right)+a_{2}\left(\frac{\ln (x-C)-A}{B}\right)^{2}+a_{3}\left(\frac{\ln (x-C)-A}{B}\right)^{3}+a_{4}\left(\frac{\ln (x-C)-A}{B}\right)^{4}\right)^{-4}\right)^{N} \text { for } x \geq C \\ 0 \text { for } x<C\end{array}\right.$

In which:

$a_{1}=0.196854$

$a_{2}=0.115194$

$a_{3}=0.000344$

$a_{4}=0.019527$

III.11.3 Inverse cumulative distribution functions

Inverse Gumbel:

$$
\xi\left(\mathrm{F}_{\underline{x}}(\xi)\right)=\mathrm{A}-\mathrm{B} \ln \left(-\ln \sqrt[N]{\mathrm{F}_{\underline{x}}(\xi)}\right)
$$

Inverse Normal:

$$
\xi\left(F_{x}(\xi)\right)=\left\{\begin{array}{l}
A-B \cdot 5.531\left[\left(\frac{1-F_{x}(\xi)}{F_{x}(\xi)}\right)^{0.1193}-1\right] \text { for } F_{x}(\xi) \geq \frac{1}{2} \\
\left.A+B \cdot 5.531]\left(\frac{F_{x}(\xi)}{1-F_{x}(\xi)}\right)^{0.1193}-1\right] \text { for } F_{x}(\xi)<\frac{1}{2}
\end{array}\right.
$$

Inverse LogNormal:

$$
\begin{aligned}
& \mathrm{y}=\left\{\begin{array}{l}
\mathrm{A}-\mathrm{B} \cdot 5.531\left[\left(\frac{1-\mathrm{F}_{\underline{x}}(\xi)}{\mathrm{F}_{\underline{x}}(\xi)}\right)^{0.1193}-1\right] \text { for } \mathrm{F}_{\underline{x}}(\xi) \geq \frac{1}{2} \\
\mathrm{~A}+\mathrm{B} \cdot 5.531\left[\left(\frac{\mathrm{F}_{\underline{x}}(\xi)}{1-\mathrm{F}_{\underline{x}}(\xi)}\right)^{0.1193}-1\right] \text { for } \mathrm{F}_{\underline{\underline{x}}}(\xi)<\frac{1}{2}
\end{array}\right. \\
& \xi\left(F_{\underline{x}}\right)=C+e^{y}
\end{aligned}
$$


Inverse Weibull:

$$
\xi\left(\mathrm{F}_{\underline{x}}(\xi)\right)=\mathrm{A}-\mathrm{B} \sqrt[\mathrm{C}]{\ln \left(1-\sqrt[\mathbf{N}]{\mathrm{F}_{\underline{\underline{x}}}(\xi)}\right)}
$$

Inverse Rayleigh:

$$
\xi\left(F_{x}(\xi)\right)=A \sqrt{\frac{-\ln \left(1-\sqrt[N]{F_{\mathbf{x}}(\xi)}\right)}{2}}
$$

III.11.4 Oveniew of available probability density functions

Gumbel:

$$
f_{\underline{x}}(\xi)=\frac{N \cdot F_{\underline{x}}(\xi)^{N-1}}{B} \cdot e^{-\left(\frac{x-A}{B}+e^{-\frac{x-A}{B}}\right)}
$$

Rayleigh:

$$
f_{\underline{\underline{x}}}(\xi)=4 N \cdot F_{\underline{x}}(\xi)^{N-1}\left(\frac{x}{A^{2}}\right) \cdot e^{-2\left(\frac{x}{A}\right)^{2}}
$$

Weibull:

$$
f_{\underline{x}}(\xi)=\left\{\begin{array}{l}
\frac{C \cdot N \cdot F_{\underline{x}}(\xi)^{N-1}}{A} \cdot\left(\frac{\xi-A}{B}\right)^{C-1} \cdot e^{-\frac{x-A}{B}} \text { for } \xi \geq A \\
0 \text { for } \xi<A
\end{array}\right.
$$

Normal:

$$
\mathrm{f}_{\underline{x}}(\xi)=\frac{1}{\sqrt{2 \pi} \mathrm{B}} \mathrm{e}^{\frac{-(\xi-A)^{2}}{2 \mathrm{~B}^{2}}}
$$


Lognormal:

$$
f_{x}(\xi)=\frac{1}{\sqrt{2 \pi} B \xi} e^{-\frac{(\ln \xi-A)^{2}}{2 B^{2}}}
$$



Annex IV: Overview of input and output for all calculations 



\begin{tabular}{|c|c|c|c|c|c|c|c|c|c|}
\hline \multirow{5}{*}{$\begin{array}{l}\text { Run } \\
\text { number }\end{array}$} & \multicolumn{9}{|l|}{ Input } \\
\hline & \multicolumn{5}{|c|}{ Hydraulic boundary conditions } & \multirow{2}{*}{\multicolumn{3}{|c|}{ Cost variables }} & \multirow{4}{*}{$\begin{array}{l}\text { Transmission } \\
\text { used (yes/no) }\end{array}$} \\
\hline & \multicolumn{3}{|l|}{ Yearly } & \multicolumn{2}{|l|}{ Daily } & & & & \\
\hline & d & $\mathbf{H}_{\mathbf{s}}$ & $\mathbf{H}_{\mathrm{d}}$ & d & $\mathbf{H}_{\mathrm{s}}$ & $\mathbf{r}^{\prime}$ & g & $\mathbf{N}$ & \\
\hline & [m] & [m] & [m] & [m] & [m] & [\%] & [\%] & [years] & \\
\hline 1 & 15 & $G(2.15,0.21)$ & $G(4.30,0.42)$ & - & - & 0 & 0 & 50 & No \\
\hline 2 (base) & 15 & $G(2.15,0.21)$ & $G(4.30,0.42)$ & - & - & 5 & 3 & 50 & No \\
\hline 3 & 15 & $G(2.15,0.21)$ & $G(4.30,0.42)$ & - & - & 5 & 0 & 50 & No \\
\hline 4 & 15 & $\mathrm{G}(2.15,0.21)$ & $G(4.30,0.42)$ & - & - & 10 & 0 & 50 & No \\
\hline 5 & 15 & $\mathrm{G}(2.15,0.21)$ & $G(4.30,0.42)$ & - & - & 5 & 3 & 25 & No \\
\hline 6 & 15 & $\mathrm{G}(2.15,0.21)$ & $G(4.30,0.42)$ & - & - & 5 & 3 & 100 & No \\
\hline 7 & $N(12.15,1)^{365}$ & $G(2.15,0.21)$ & $G(4.30,0.42)$ & - & - & 5 & 3 & 50 & No \\
\hline 8 & 15 & $G(2.15,0.21)$ & $G(4.30,0.42)$ & 15 & $G(0.91,0.21)$ & 5 & 3 & 50 & Yes \\
\hline 9 & $N(12.15,1)^{365}$ & $\mathrm{G}(2.15,0.21)$ & $\mathrm{G}(4.30,0.42)$ & $N(12.15,1)$ & $G(0.91,0.21)$ & 5 & 3 & 50 & Yes \\
\hline
\end{tabular}




\begin{tabular}{|c|c|c|c|c|c|c|c|c|c|c|c|}
\hline \multirow{3}{*}{$\begin{array}{l}\text { Run } \\
\text { nr. }\end{array}$} & \multicolumn{11}{|c|}{ Results (optimal design) } \\
\hline & $h_{c}$ & $\mathrm{~B}_{\mathrm{c}}$ & $\mathbf{A}_{\mathrm{c}}$ & $\mathbf{h}_{\mathfrak{c}} / \mathbf{B}_{\mathfrak{c}}$ & $\mathbf{P}_{\mathrm{r} ; \mathrm{SIS}}$ & $\mathbf{P}_{r, \text { ULS }}$ & $\mathbf{P}_{\text {slid }}$ & $\mathbf{P}_{\text {min }}$ & $P_{\max }$ & $\mathbf{P}_{\text {low }}$ & $P_{\mathrm{up}}$ \\
\hline & {$[\mathrm{m}]$} & [m] & {$\left[\mathrm{m}^{2}\right]$} & {$[-]$} & [1/day] & {$\left[10^{-4} /\right.$ year $]$} & {$\left[10^{-4} /\right.$ year $]$} & {$\left[10^{-4} /\right.$ year $]$} & {$\left[10^{-4} /\right.$ year $]$} & {$\left[10^{-4} /\right.$ year] } & {$\left[10^{-4} /\right.$ year $]$} \\
\hline 1 & 22.62 & 20.16 & 456.0 & 1.12 & - & 2.98 & 0.17 & 2.98 & 2.64 & 2.98 & 5.79 \\
\hline 2 & 22.50 & 19.98 & 449.6 & 1.13 & - & 3.97 & 0.15 & 3.97 & 2.91 & 3.97 & 7.03 \\
\hline 3 & 22.33 & 19.35 & 432.1 & 1.15 & - & 9.32 & 0.47 & 9.32 & 6.01 & 9.32 & 15.8 \\
\hline 4 & 22.32 & 18.67 & 416.7 & 1.20 & - & 17.8 & 0.68 & 17.8 & 13.4 & 17.8 & 31.9 \\
\hline 5 & 22.48 & 18.73 & 421.1 & 1.20 & - & 14.4 & 0.52 & 14.4 & 14.2 & 14.4 & 29.0 \\
\hline 6 & 22.72 & 20.14 & 457.6 & 1.13 & - & 3.25 & 0.10 & 2.91 & 3.25 & 3.25 & 6.26 \\
\hline 7 & 22.58 & 20.18 & 458.4 & 1.11 & - & 4.34 & 0.15 & 4.28 & 2.75 & 4.28 & 7.18 \\
\hline 8 & 22.56 & 19.52 & 440.4 & 1.16 & 0.00 & 6.16 & 0.28 & 6.16 & 5.81 & 6.16 & 12.2 \\
\hline 9 & 22.67 & 19.85 & 450.0 & 1.14 & 0.00 & 6.09 & 0.31 & 5.79 & 4.97 & 5.79 & 11.1 \\
\hline
\end{tabular}


Annex V: Comparison of numerical and analytical results 



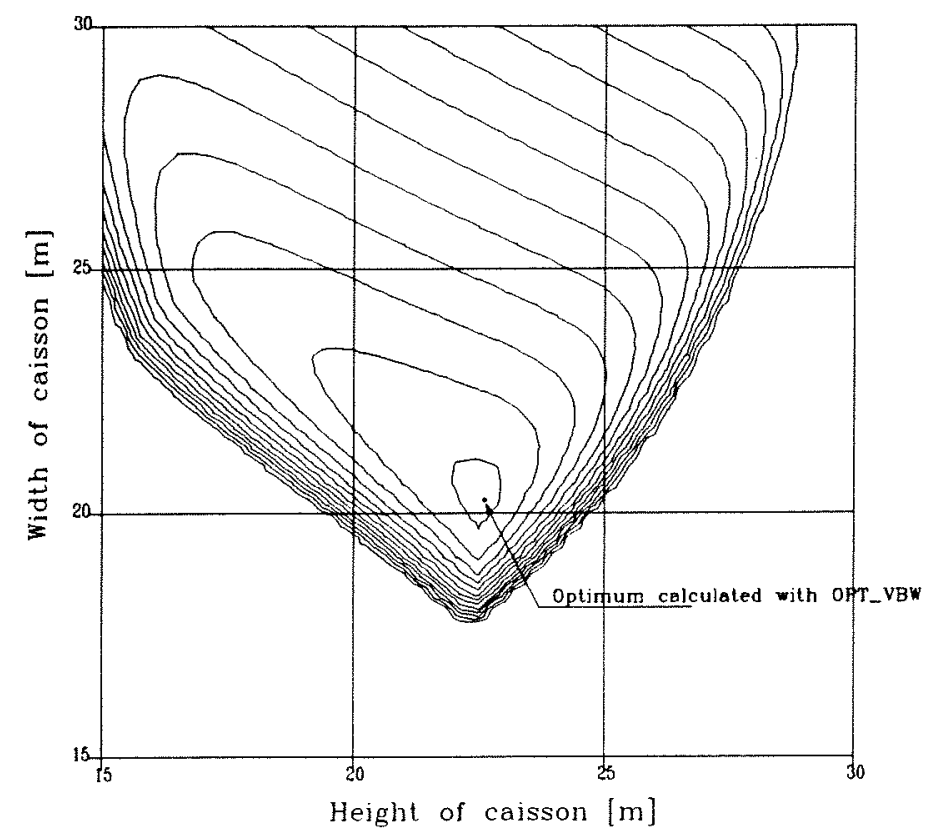

Figure V.1: Comparison of numerical and analytical results: Run number $1\left(\mathrm{r}^{\prime}-\mathrm{g}=0.00\right.$, no transmission)

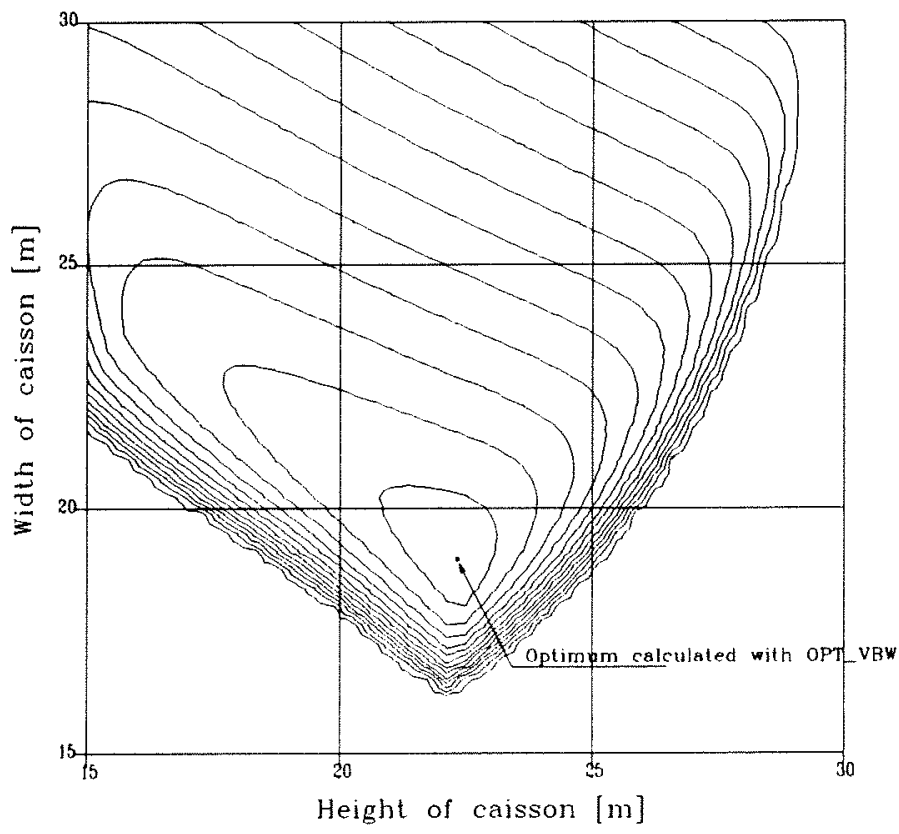

Figure V.2: Comparison of numerical and analytical results: Run number 2 ( $\mathrm{r}^{\prime}-\mathrm{g}=0.10$, no tranmission) 


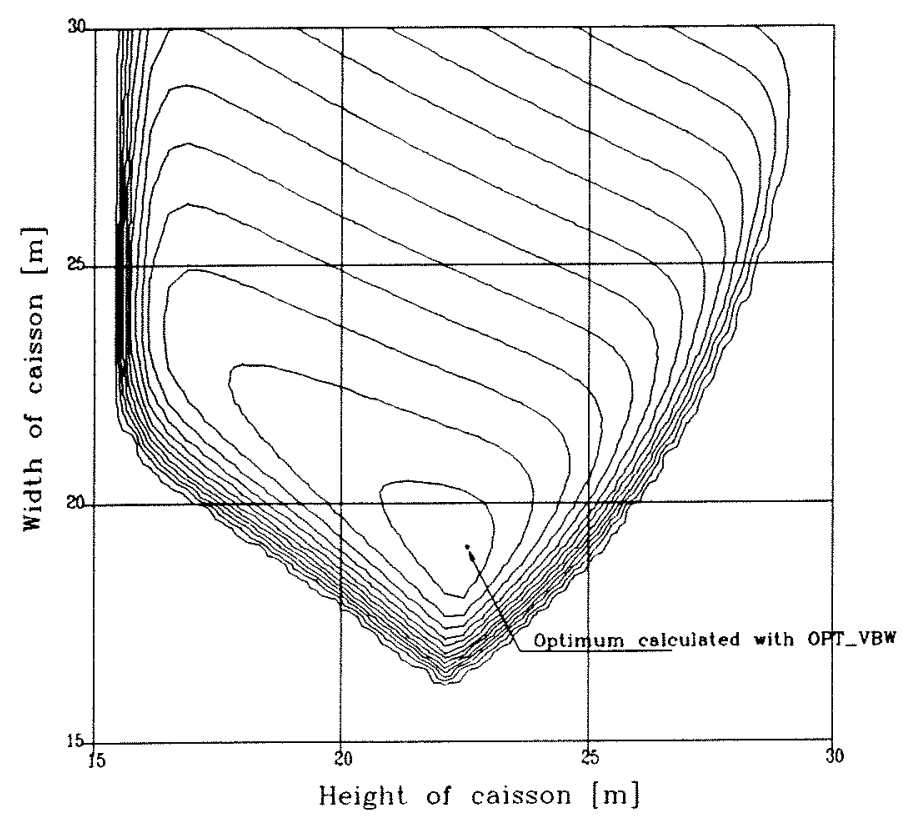

Figure V.3: Comparison of numerical and analytical results:

Run number 8 ( $r^{\prime}-\mathrm{g}=0.02$, transmission included) 
Annex VI: Numerical results for four interest rates 



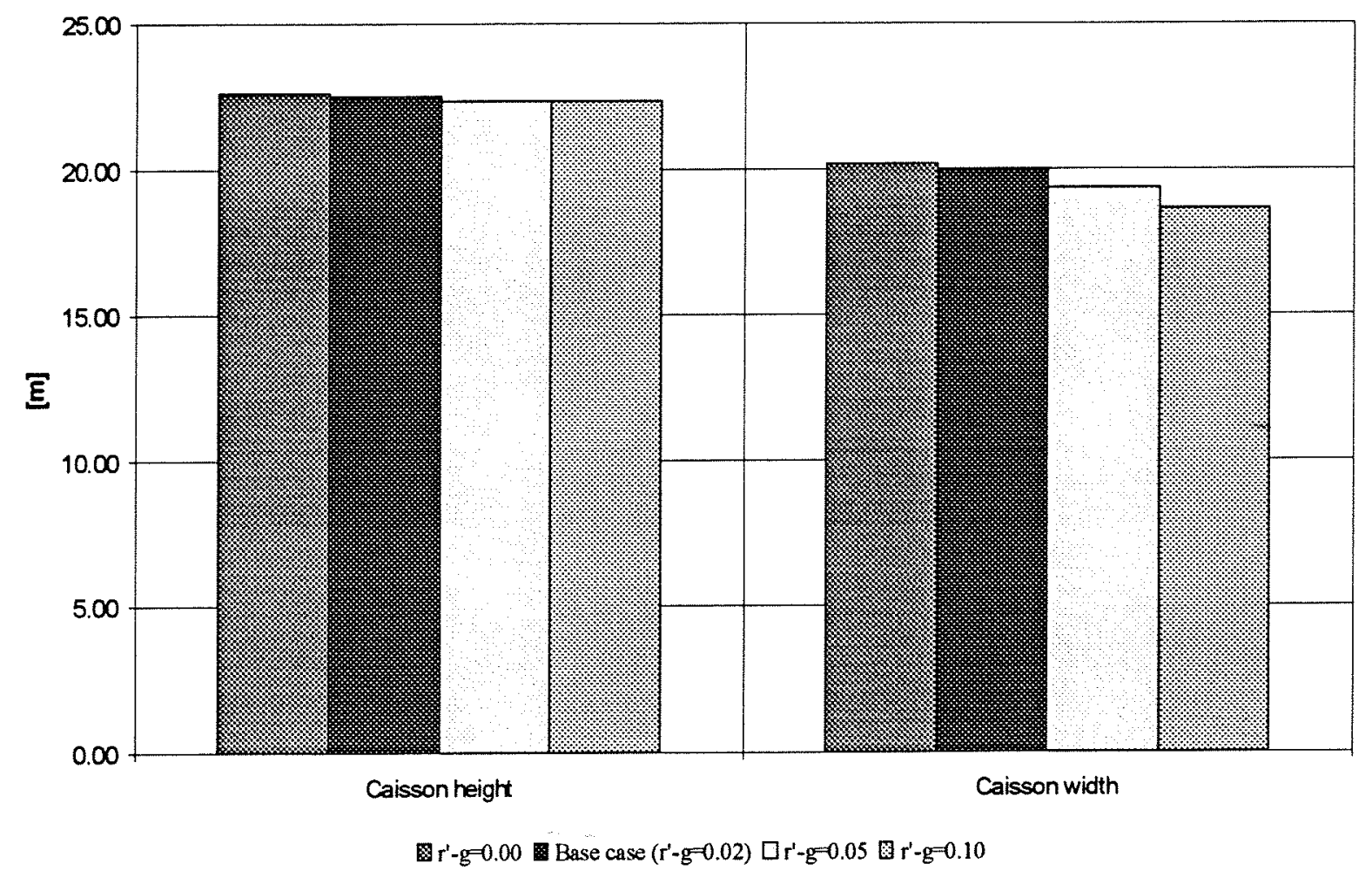

Figure VI.1: Optimal height and width of the caisson

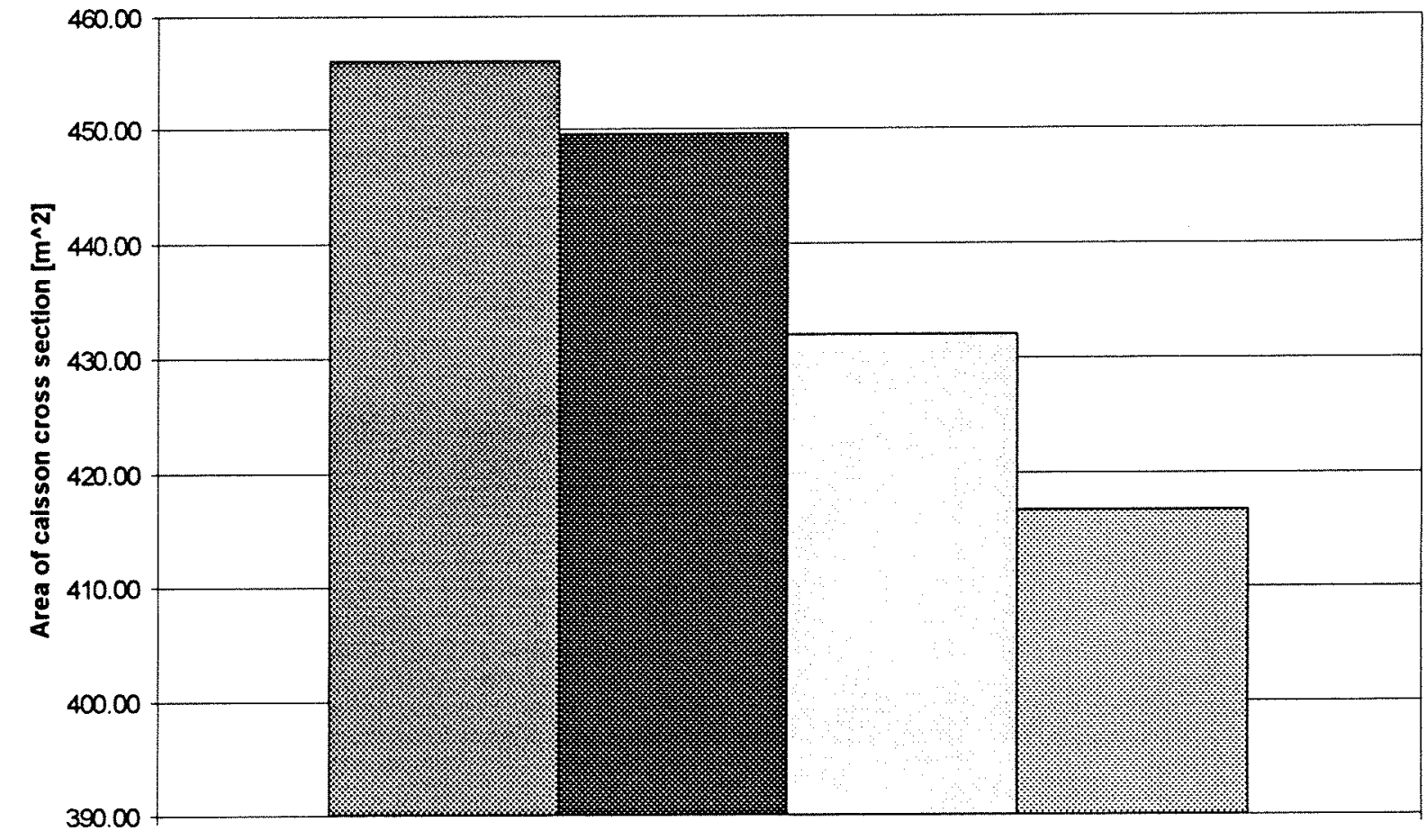

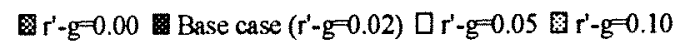

Figure VI.2: Optimal area of the caisson cross section 


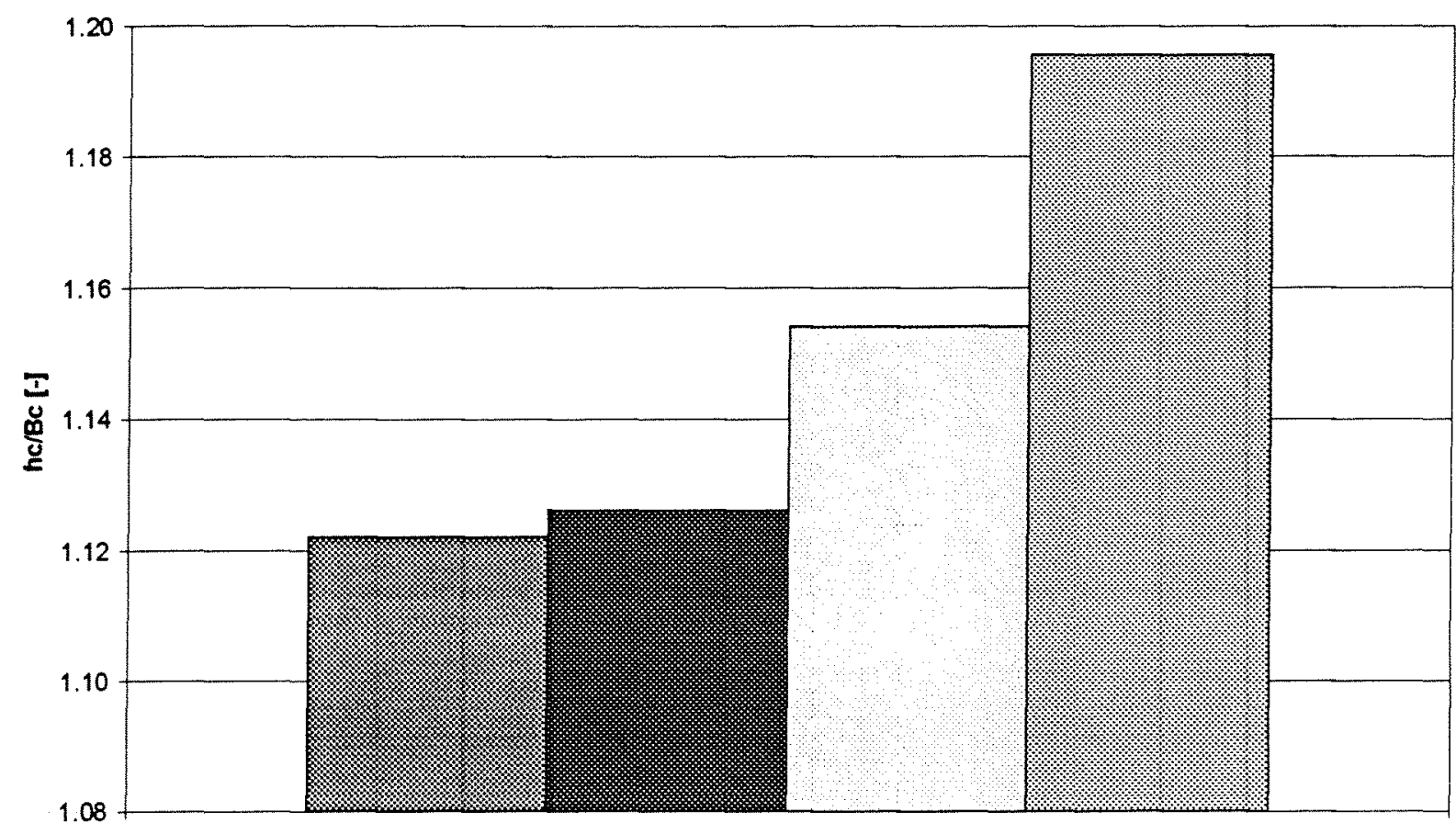

$\mathrm{r}^{\prime}-\mathrm{g}=0.00$ Base case $\left(\mathrm{r}^{\prime}-\mathrm{g}=0.02\right) \square \mathrm{r}^{\prime}-\mathrm{g}=0.05$ : $\mathrm{O} \mathrm{r}^{\prime}-\mathrm{g}=0.10$

Figure VI.3: Optimal heightwidth ratios

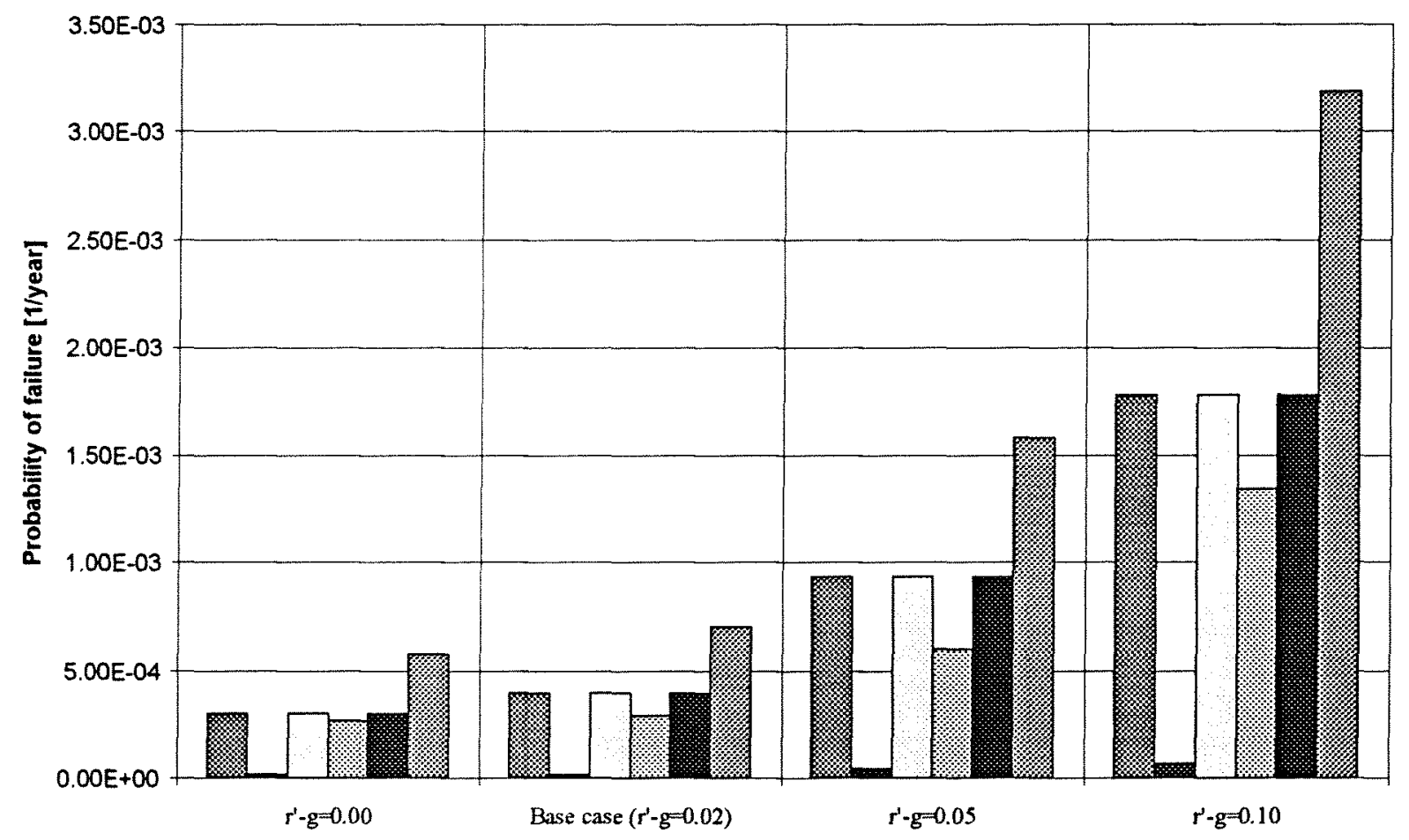

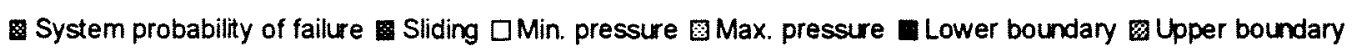

Figure VI.4: Individual failure probabilities for optimal designs 
Annex VII: Numerical results for three life times 


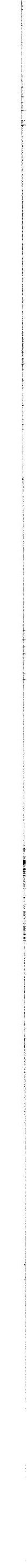




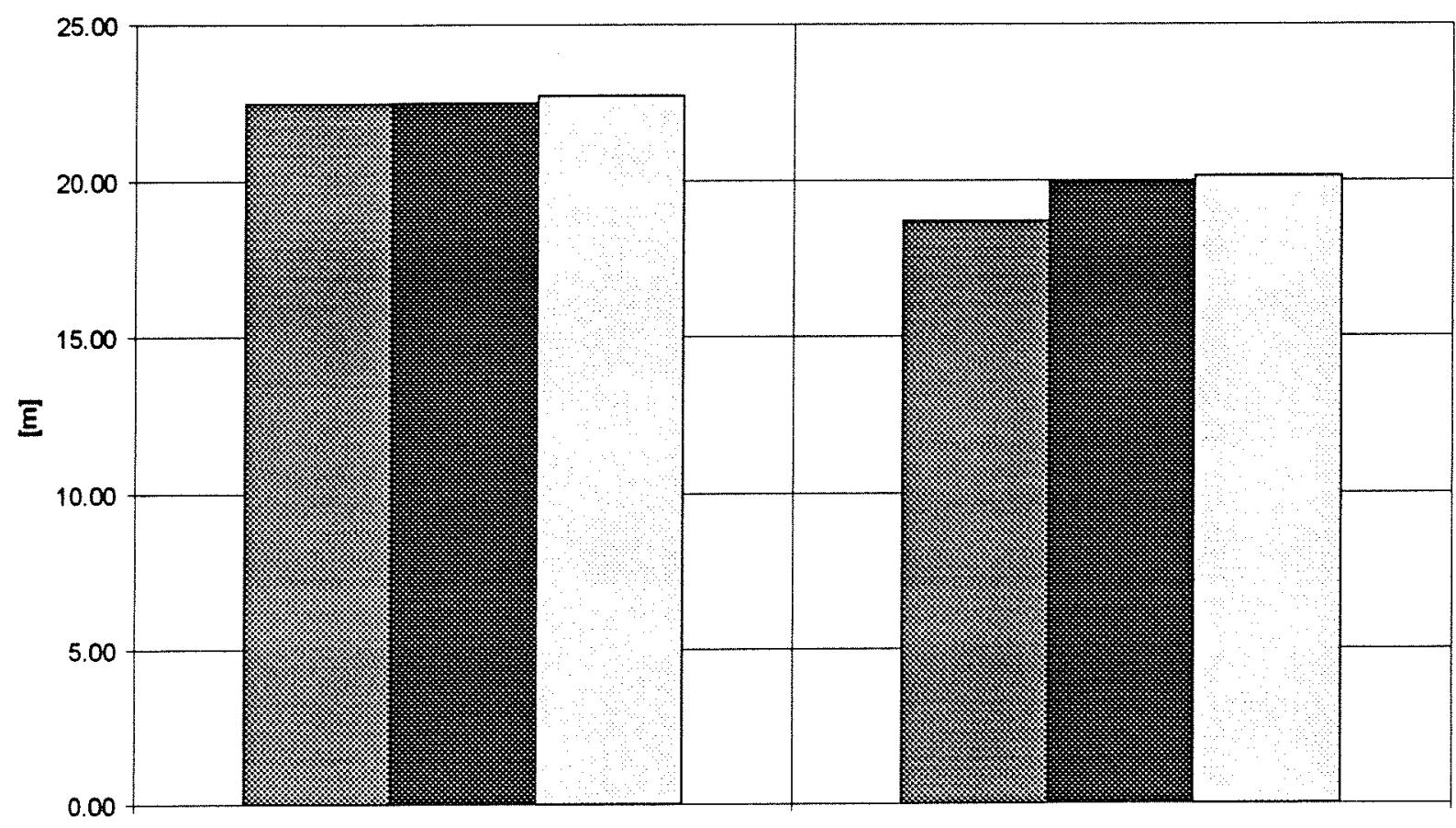

L Lifetime 25 years Base case ( 50 years) $\square$ Lifetime 100 years

Figure VII.1: Optimal height and width of the caisson

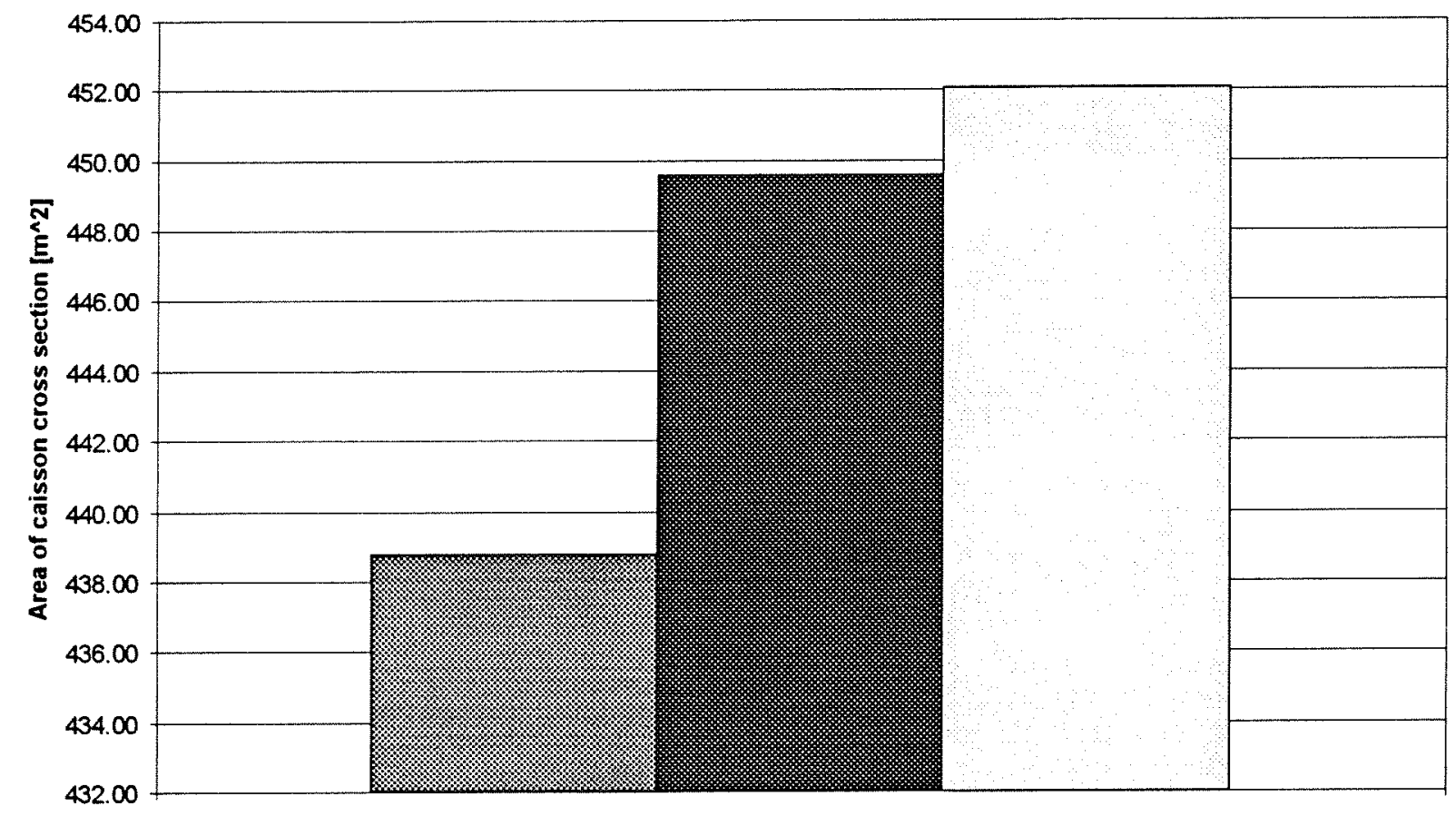

Lifetime 25 years Base case ( 50 years) $\square$ Lifetime 100 years

Figure VII.2: Optimal area of caisson cross section 


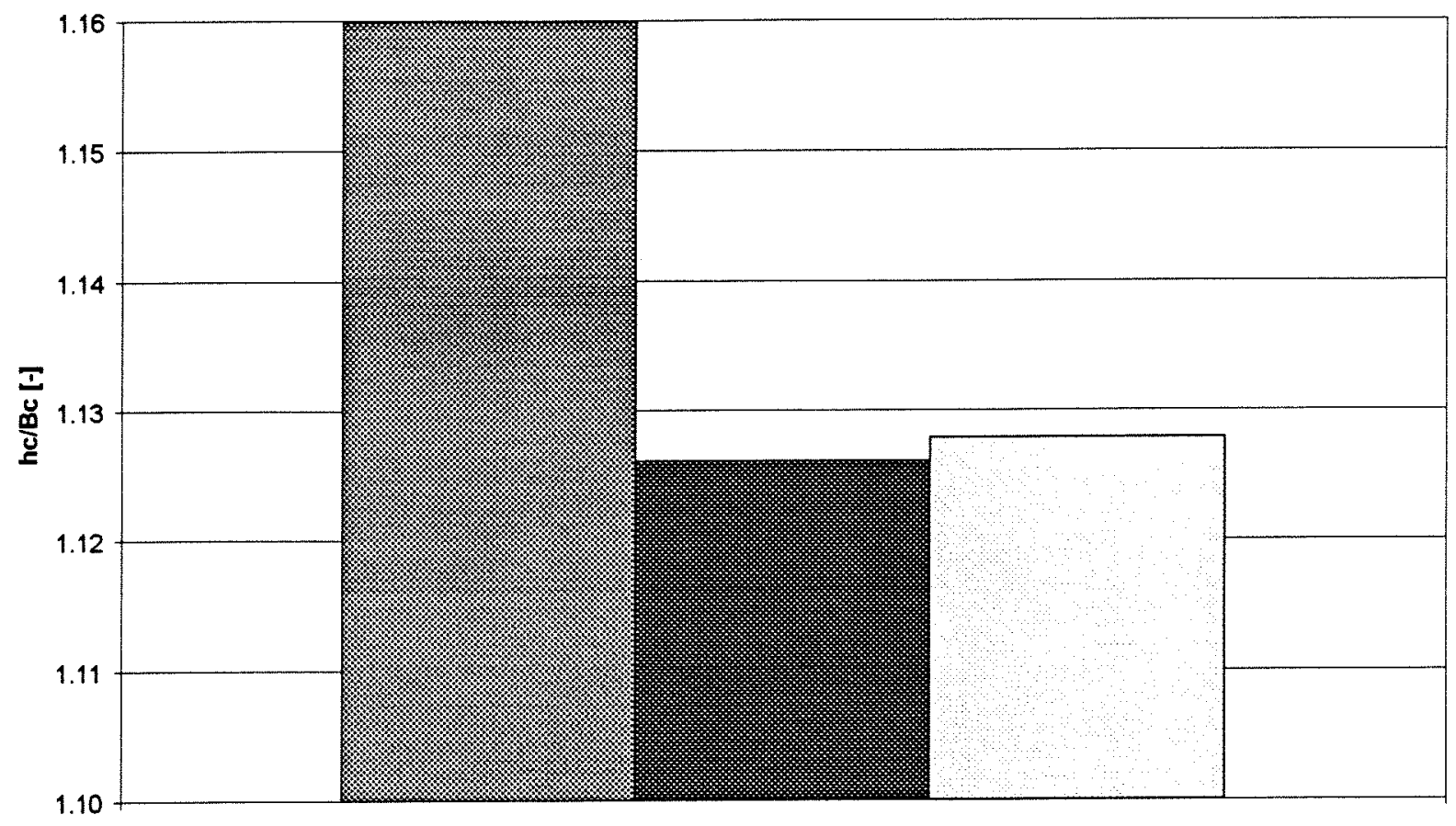

Lifetime 25 years Base case ( 50 years) $\square$ Lifetime 100 years

Figure VII.3: Optimal height/width ratios

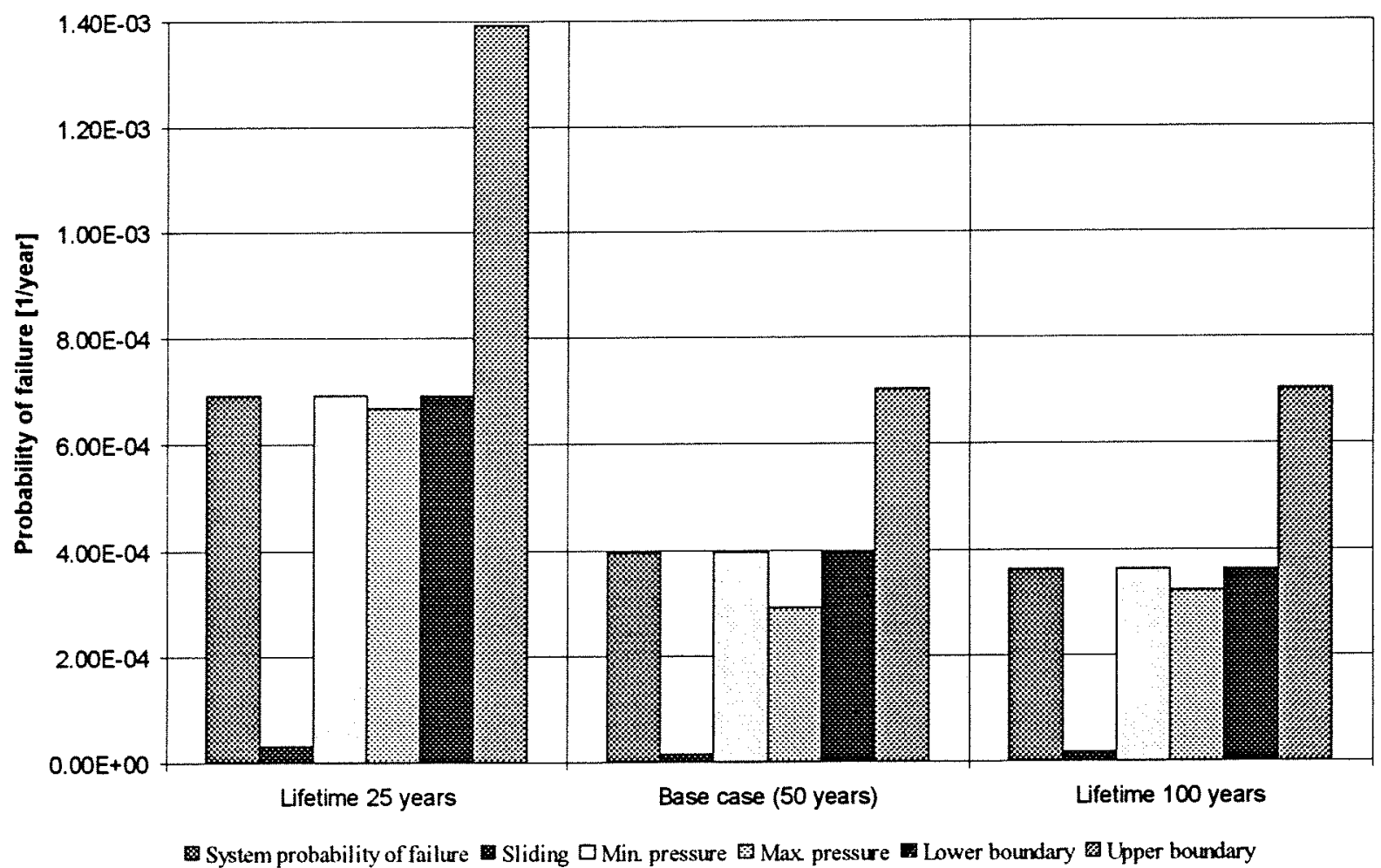

Figure VII.4: Individual failure probabilities 
Annex VIII: Numerical results for two random variables 



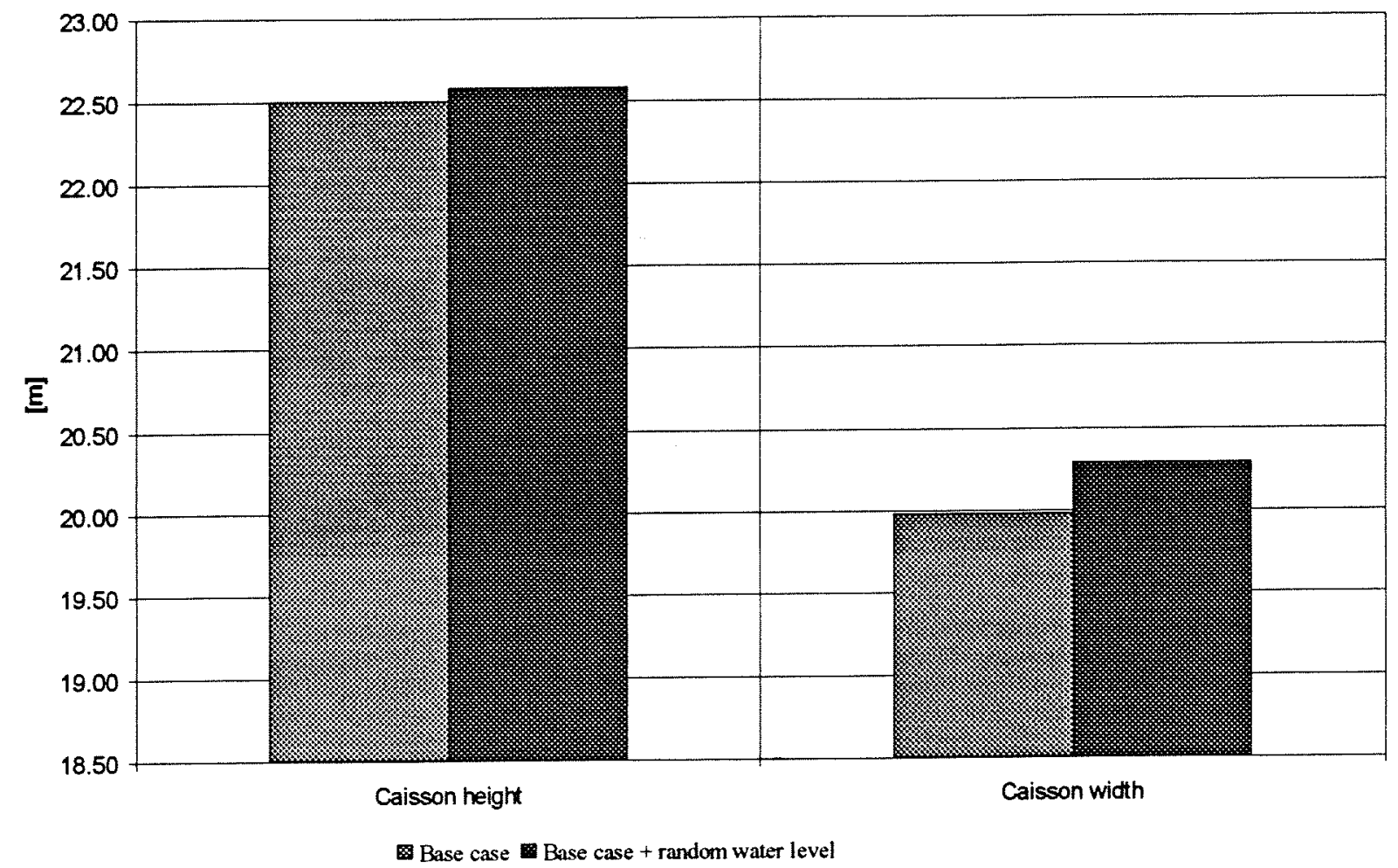

Figure VIII.1: Optimal height and width of the caisson

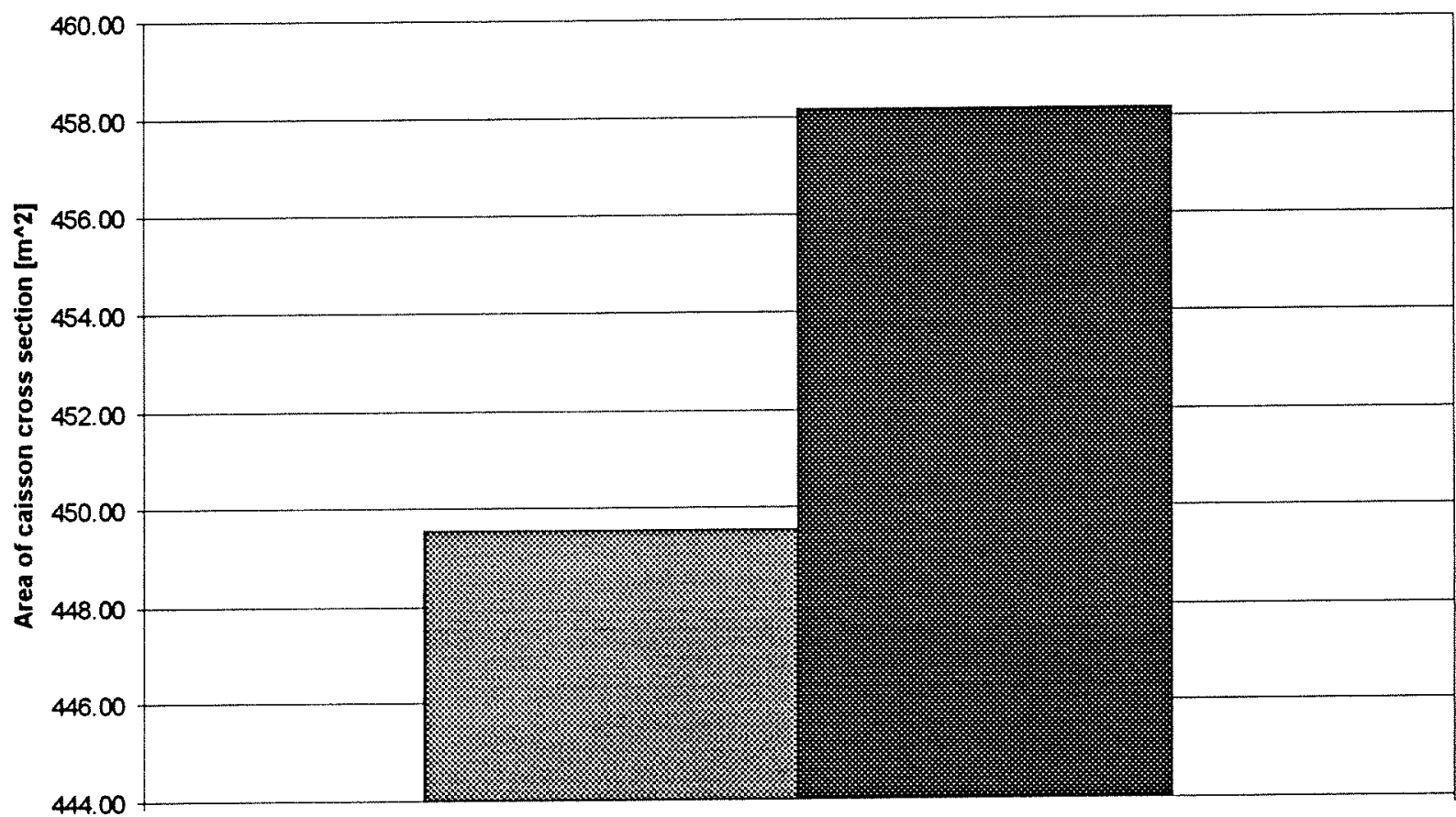

Base case Base case + random water level

Figure VIII.2: Optimal area of caisson cross section 


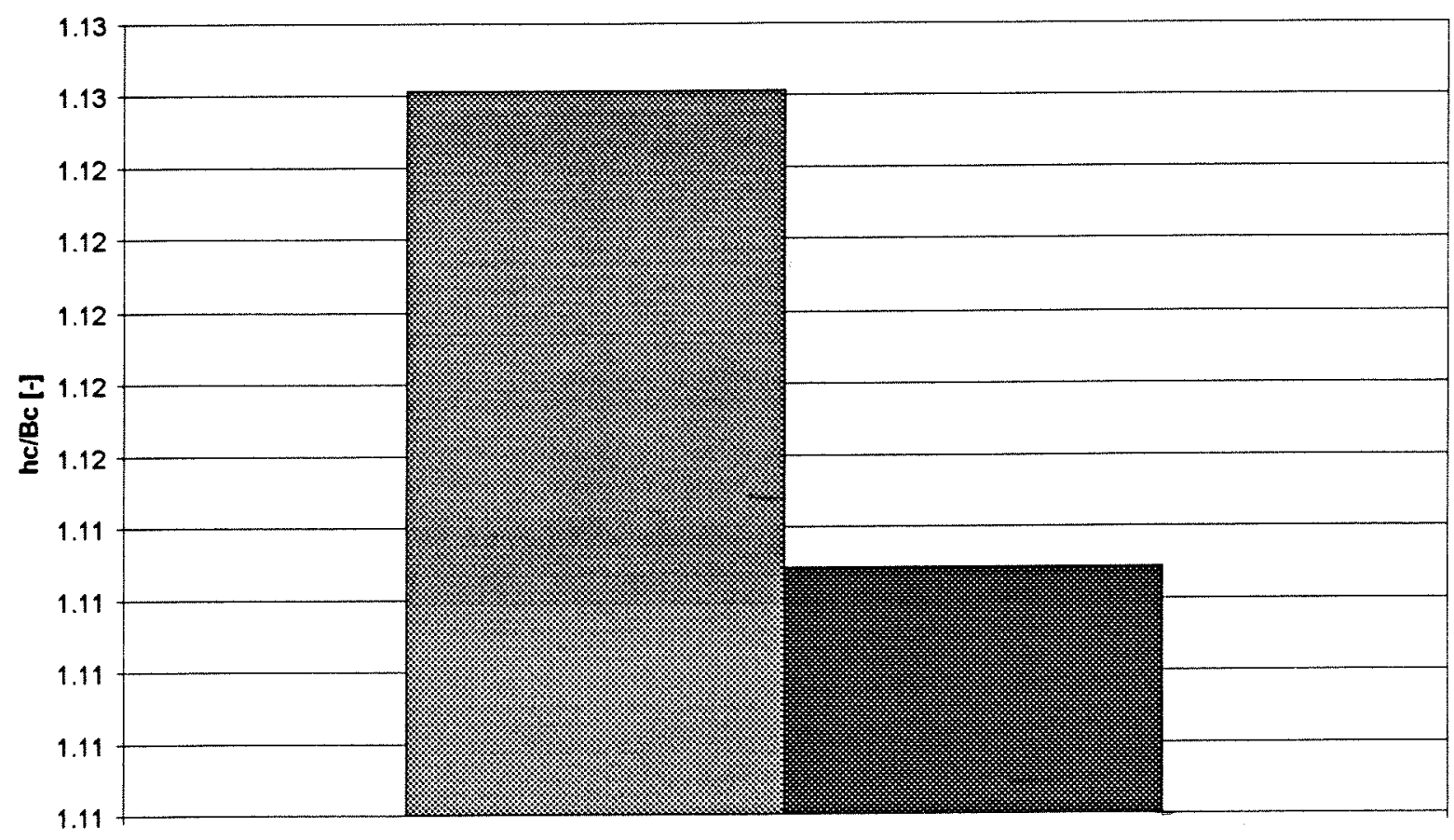

Base case $\mathrm{O}$ Base case + random water level

Figure VIII.3: Optimal height/width ratios

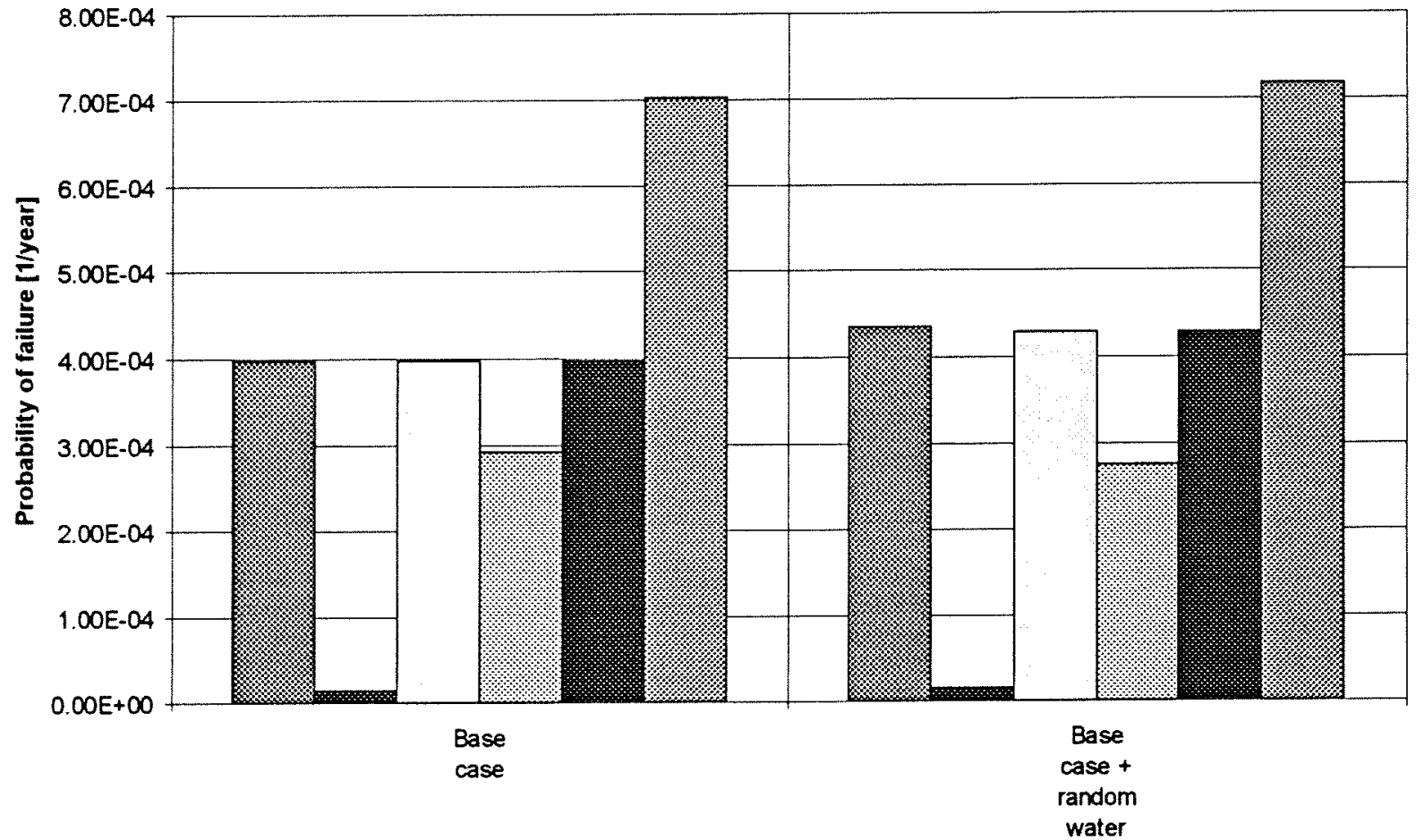

System probability of failure Sliding $\square$ Min pressure $\mathrm{Max}$ pressure Lower boundary

Figure VIII.4: Individual probabilities of failure 
Annex IX: Numerical results including transmission 



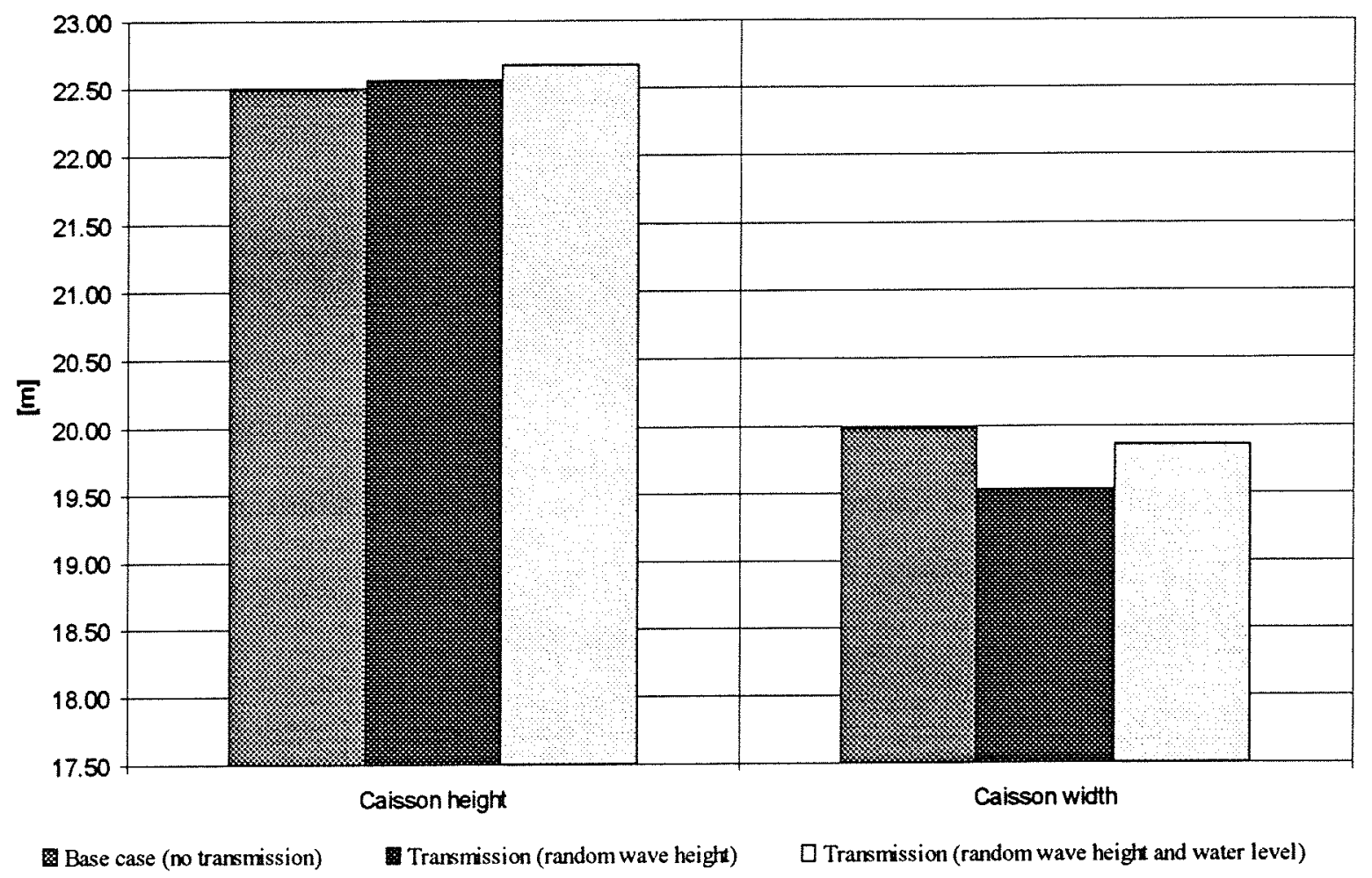

Figure IX.1: Optimal height and width of the caisson

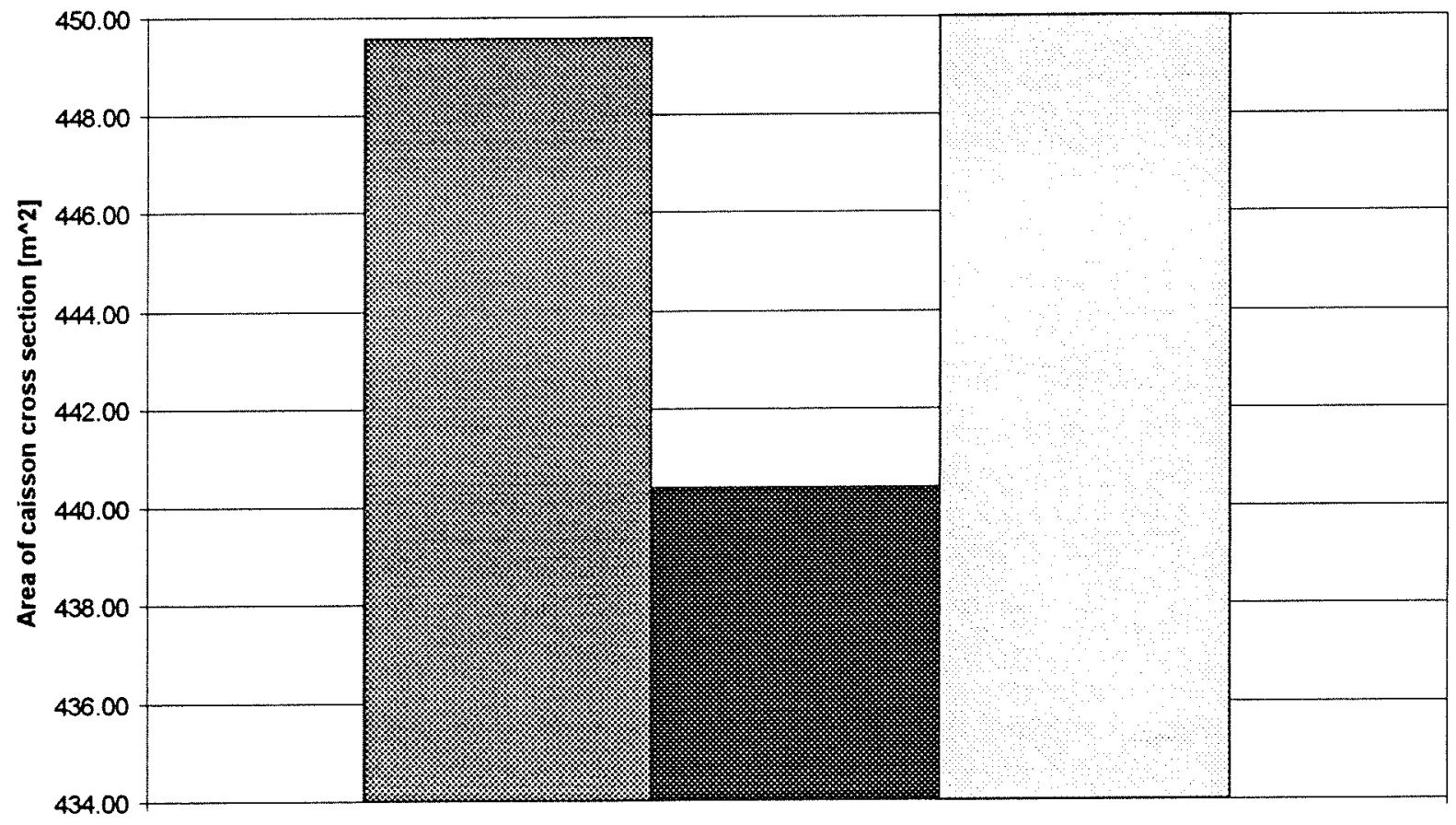

O Base case (no transmission) Transmission (random wave heigit) $\square$ Transmission (random wave height and water level)

Figure IX.2: Optimal area of caisson cross section 


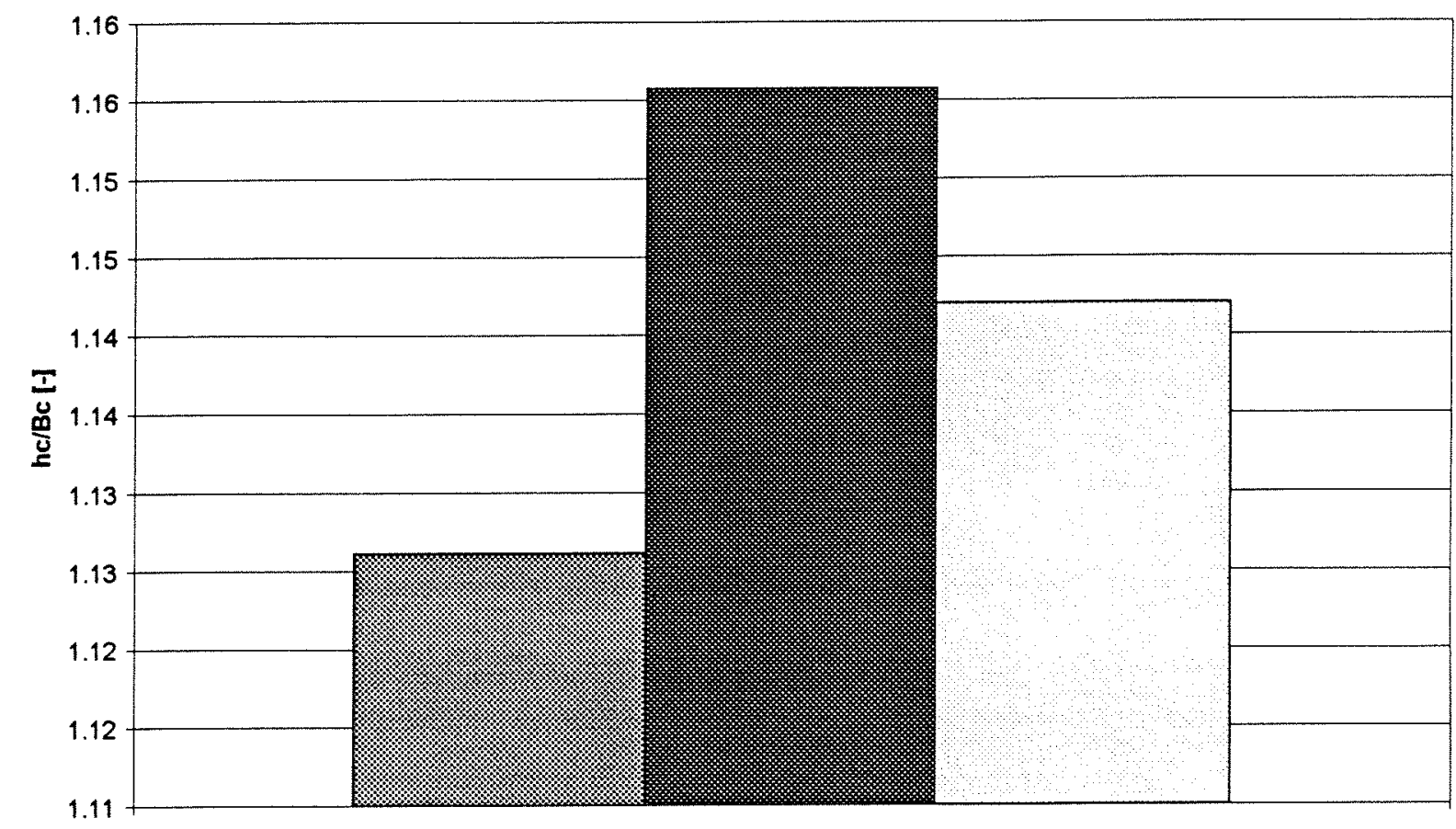

Base case (no transmission) 1 Transmission (random wave height) $\square$ Transmission (random wave height and water level) Figure IX.3: Optimal height/width ratio

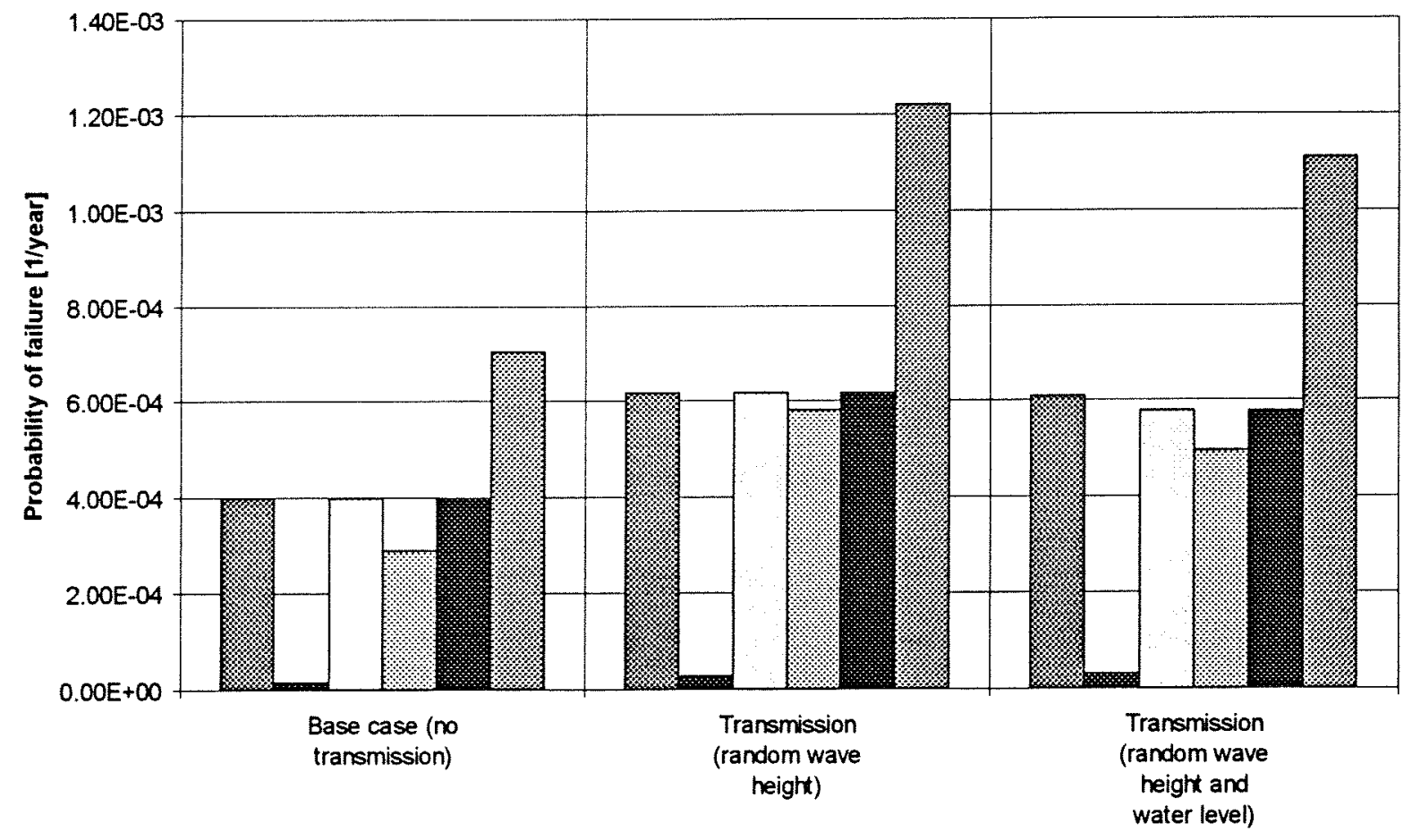

System probability of failure Sliding $\square$ Min pressure $\gtrsim$ Max pressure

Figure IX.4: Individual failure probabilities 